University of Massachusetts Amherst

ScholarWorks@UMass Amherst

Doctoral Dissertations 1896 - February 2014

$1-1-1976$

\title{
A study of the perceptions of selected small Massachusetts manufacturers toward exporting.
}

Ralph A. Rieth

University of Massachusetts Amherst

Follow this and additional works at: https://scholarworks.umass.edu/dissertations_1

\section{Recommended Citation}

Rieth, Ralph A., "A study of the perceptions of selected small Massachusetts manufacturers toward exporting." (1976). Doctoral Dissertations 1896 - February 2014. 5946.

https://scholarworks.umass.edu/dissertations_1/5946

This Open Access Dissertation is brought to you for free and open access by ScholarWorks@UMass Amherst. It has been accepted for inclusion in Doctoral Dissertations 1896 - February 2014 by an authorized administrator of ScholarWorks@UMass Amherst. For more information, please contact scholarworks@library.umass.edu. 
312066013545684 


\section{A STUDY OF THE PERCEPTIONS OF \\ SELECTED SMALL MASSACHUSETTS MANUFACTURERS \\ TOWARD EXPORTING}

A Dissertation Presented

By

RALPH A. RIETH, JR.

Submitted to the Graduate School of the University of Massachusetts in partial

fulfillment of the requirements for the degree of DOCTOR OF PHILOSOPHY

May

Major Subject: Business Administration 


\section{(C) 1976}

RALPH ARTHUR RIETH, JR.

\section{ALL RIGHTS RESERVED}


A STUDY OF THE PERCEPTIONS OF

SELECTED SMALL MASSACHUSETTS MANUFACTURERS

TOWARD EXPORTING

A dissertation

By

RALPH A. RIETH, JR .

Approved as to style and content by:

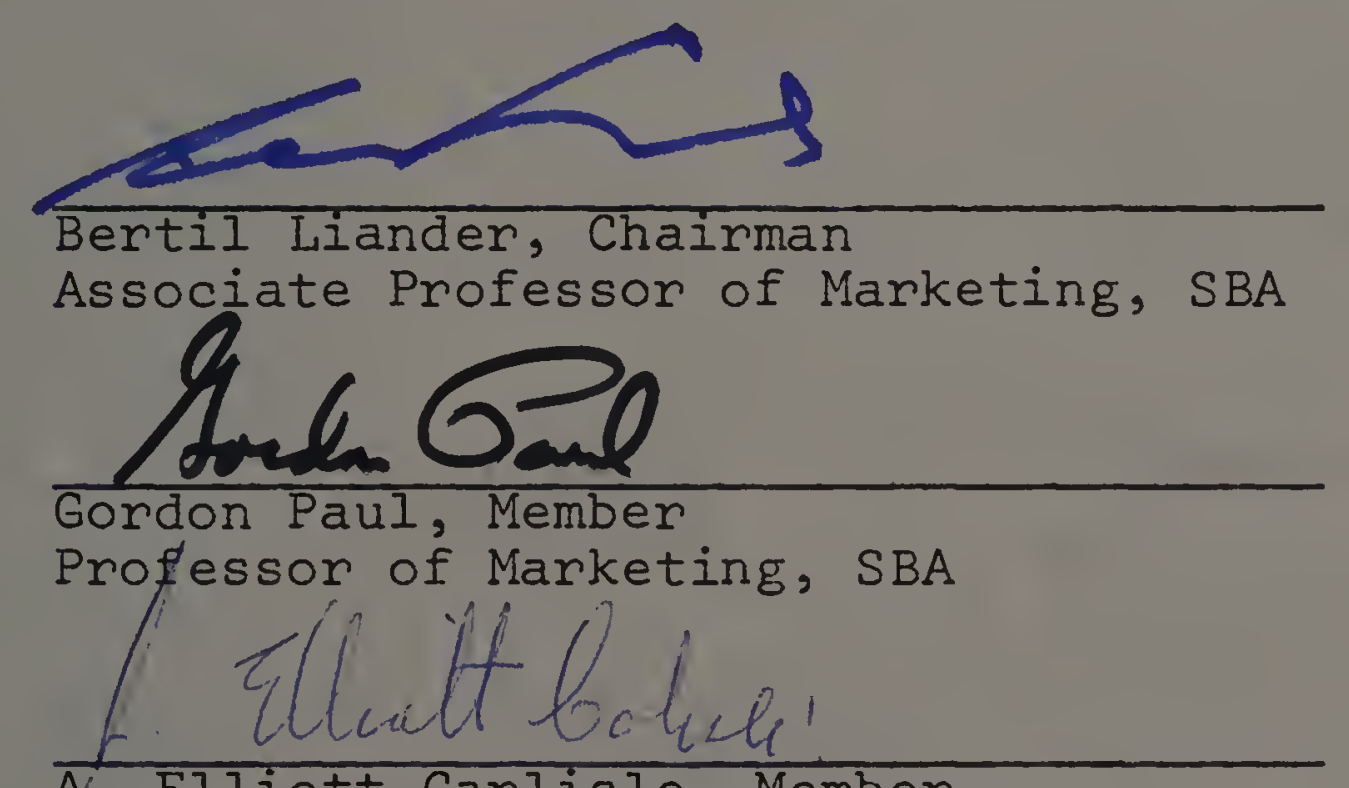

A. Elliott Carlisle, Member

Professor of Management, SBA

Banbara B Bunn

Barbara B. Burn, Outside Member

Adjunct Professor of Education

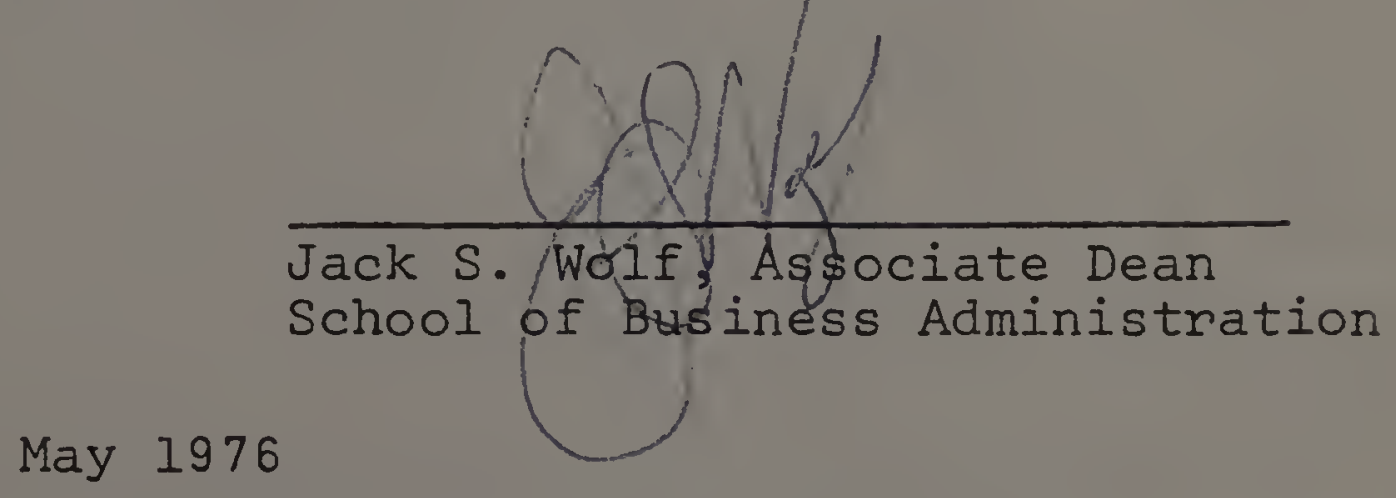




\section{ACKNOWLEDGEMENTS}

No research project of this size can be completed without the help and support of many individuals, and I wish to thank the people whose assistance and encouragement made this dissertation possible. First I would like to express my appreciation to the members of my dissertation committee. Bertil Liander, as chairman, helped develop the ideas which led to the research project, and he provided encouragement and guidance during the inevitable periods when everything went wrong. Gordon Paul made the suggestion that led to the research method used for this study. He also acted as surrogate chairman while Professor Liander was on sabbatical and provided helpful guidance during the writing stage. Elliott Carlisle provided guidance at numerous stages in the research, and his encouragement and editorial criticisms were especially helpful in the writing stage. Barbara Burn, as the non-Business school member, provided a viewpoint which was helpful, and her enthusiasm and encouragement were appreciated.

Thanks are due to many others also. To Jean Pierre Jeannet, my Swiss friend, who acted as a sounding board for my ideas and whose critical appraisal of them was very helpful. To Roger Calentone who was never too busy to help or just to talk. His knowledge of computers and multivariate techniques helped me over many rough spots, and he helped 
both with the computer programming and with the interpretation of the data. To Donald Frederick who helped to explain the factor analysis results. To my fellow students in the doctoral program who accepted the "old man" and made him feel welcome.

Thanks are also due to the people outside the University who helped: to Louis J. Camarra of the Norton Company and to Ernest J. Enright of the International Marketing Institute for their help in enlisting companies for the survey; to Theodore R. Byrne, Director of Business Research at American International College, and his staff for their assistance; and to the fifty-nine executives who freely gave time out of their busy schedules so that this research could be completed.

Thanks to Vesta Powers, not only for her skill and cooperation in typing the final copy of the dissertation, but also for her cheery words and helpful assistance during the entire research process.

My greatest debt is to my wife, Em. Without her love and encouragement it would have been impossible for me to finish this work, and to her I dedicate this dissertation. 
ABSTRACT

A STUDY OF THE PERCEPTIONS OF

SELECTED SMALL MASSACHUSETTS MANUFACTURERS

TOWARD EXPORTING

By: Ralph A. Rieth, Jr., A.B., Dartmouth College

M.B.A., University of Massachusetts Ph.D., University of Massachusetts

Directed by: Dr. Bertil Liander

In an attempt to discover some of the reasons for the failure of United States export expansion programs to attain their desired goals, this study investigated the perception toward exporting of small, high technology Massachusetts manufacturers. The hypothesis of the study was that exporters would differ from non-exporters in their perceptions of such factors of exporting as risk, profit potential, costs, problems, and personal rewards.

A convenience sample of fifty-nine small, high technology Massachusetts manufacturers ( 34 exporters and 25 nonexporters) was selected. The principal products of these companies fell into six SIC groups $(28,34,35,36,37,38)$. For each company, the decision maker responsible for deciding whether or not his company will export, was personally interviewed. A programmed interview was used to help the researcher draw a composite picture of both the exporting and non-exporting firms and of their export decision makers. 
At the conclusion of the interview, each decision maker was asked to rate forty-nine statements about exporting on a six point Likert scale from stronly disagree to strongly agree. These statements were developed to measure the five factors of exporting (risk, profit potential, costs, problems, and personal rewards) that were to be tested for the main hypothesis.

During the course of the interviews, seven exporters were found who did not really appear to be interested in exporting. Often they were exporting only because of pressure from one of their large American customers, and they explained to the researcher that exporting was a nuisance which they would avoid if they could. These seven were labeled non-committed exporters while the other twentyseven who actively sought export business were called committed exporters. Two sets of tests were run. First, all exporters were compared with all non-exporters as originally planned. Second, the committed exporters were compared with the non-committed exporters and the non-exporters.

The results were tested using both a Kolmogorov-Sminnov non-parametric test and a multivariate discriminant analysis. The non-parametric analysis viewed each of the statements as a separate hypothesis, and the general hypothesis was evaluated by looking at the results of the forty-nine separate tests. The discriminant analysis, on the other hand, looked at the forty-nine statements as a group in order to determine 
how well they could discriminate between the various groups. Both tests strongly supported the hypothesis that exporters perceive the risk, profit potential, costs, problems, and personal rewards of exporting differently than do the nonexporters. When the non-committed exporters were paired with the non-exporters, the results were stronger than when all of the exporters were compared with all of the non-exporters, indicating that the perceptions toward exporting of the non-committed exporter tend to be closer to the nonexporter than to the committed exporter.

Very little research has been done on the export practices of small manufacturers. This study offers some insights into the reasons why many small companies do not export. It also indicates that present government policies and practices to expand exports should not be expected to have the desired results. 
TABLE OF CONTENTS

Page

ACKNOWLEDGEMENTS $\cdot \cdot \cdot \cdot \cdot \cdot \cdot \cdot \cdot \cdot \cdot \cdot \cdot \cdot \cdot \cdot \cdot \cdot \cdot$. $\cdot$.

ABSTRACT • . . . . . . . . . . . . . . . . . v vi

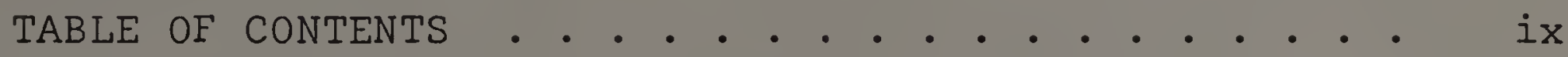

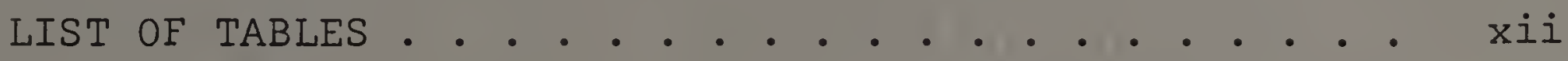

CHAPTER I - INTRODUCTION TO THE PROBLEM $\cdot$. . . . . . I

Prolegomenon ............... . . 1

Background on International Trade Theories . . . 4

The Current Problem . . . . . . . . . . . . . 11

Statement of Research Needs........... . 24

Value of the Research .............. 29

Organization of the Report . . . . . . . . . . 31

CHAPTER II - RESEARCH METHODOLOGY . • . . • • • • 33

Scope . . . . . . . . . . . . . . . . . . 33

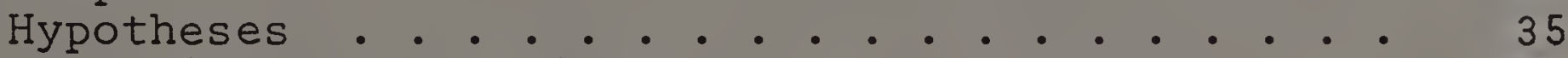

Operational Definitions . . . . . . . . . . . 37

Research Design ................. 39

The Statistical Analysis ........... . . 44

Kolmogorov-Smirnov . . . . . . . . . . . . 45

Factor Analysis . . . . . . . . . . . . 46

Discriminant Analysis .. . . . . . . . . . 46

Limitations of the Research . . . . . . . . . 47

CHAPTER III - THE RESEARCH . . . . . . . . . 50

Description of the Research Process....... 50

Selection of the Participants . . . . . . . 50

Geographic Areas Covered . . . . . . . . . . 50

Enlistment Procedures . . . . . . . . . . . 51

Problems in Balancing the Sample...... 53

Committed and Non-Committed Exporters . . . . 54

The Companies................. . . 56

Company Size............... . . . 56

Industry Classification . . . . . . . . . . 57

The Export Decision Makers . . . . . . . . . . 59

Age of Decision Makers . . . . . . . . . . . 61

Education . . . . . . . . . . . . 63

Foreign Language Capabilities . . . . . . 63

Foreign Travel................ 67

Reasons For Exporting or Not Exporting . . . . . 67 
Page

Tales of Two Exporters . . . . . . . . . 68

A View of the Non-Exporter . . . . . . . . . . 69

Why Non-Exporterd Do Not Export . . . . . . . 70

The Export Decision Makers' Views of the

Benefits and Problems of Exporting . . . . . 71

Summary of the Research Process . . . . . . . . . 72

CHAPTER IV - NONPARAMETRIC ANALYSIS OF THE RESULTS • • 74

The Decision Maker's Perception of Exporting . . 74

The Measuring Instrument . . . . . . . . . 75

Summary of the Test Results . . . . . . . . . 76

Analysis of the Kolmogorov-Smirnov Results . • • 77

Summary of the Nonparametric Analysis . • . • • . 92

CHAPTER V - THE MULTIVARIATE ANALYSIS . • • • • • • . 94

Factor Analysis . • . . . . . . . . . . . 94

Discriminant Analysis . . . . . . . . . . . . . . 97

Advantages of the Discriminant Analysis . . . 97

Computer Routine . • . . . . . . . . . . . . 98

Initial Subgroup of Variables . . . . . . . 100

Strong Variables... . . . . . . . . . . . 103

Weak Variables . . . . . . . . . . . . . . . 105

Summary of the Discriminant Analysis . . . . . . 106

CHAPTER VI - SUMMARY AND CONCLUSIONS • • • • • • • • 108

The Research Findings . . . . . . . . . . . 108

Change Agents and the Export Decision Makers . . 114

Policy Implications . • • • • • • • • • • • • 117

For Governmental Change Agents • • • • • • . 117

For the Colleges and Universities . . . . . . 120

For Governmental Policy Makers . . . . . . . . 122

Implications For Further Research . . . . . . . 124

BIBLIOGRAPHY . . . . . . . . . . . . . . . . 128 APPENDICES

A OPINIONS OF EXPORTING . . . . . . . . . . 133

B INTERVIEW GUIDE SHEET . . . . . . . . . • 138

C THE KOLMOGOROV-SMIRNOV TWO SAMPLE, ONETAILED TEST •................ 142 
D INTERVIEW LETTERS . . . . . . . . . . . . 145

E COMMENTS FROM DECISION MAKERS ABOUT THE REASONS THEY BEGAN TO EXPORT . . . . . . . 149

F REASONS GIVEN BY NON-EXPORTERS FOR NOT

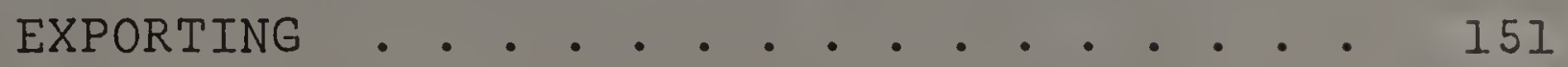

$G$ DECISION MAKERS' VIEWS OF THE BENEFITS AND PROBLEMS OF EXPORTING . . . . . . . . . . 154

H THE KOLMOGOROV-SMIRNOV ANALYSIS . . . . . 156 


\section{LIST OF TABLES}

Table

Page

3-1 INTERVIEWS GRANTED BY TYPE OF LETTER SENT • • • • 57

3-2A NUMBER OF EMPLOYEES BY EXPORT CLASSIFICATION • . 58

3-2B SUMMARY STATISTICS ON NUMBER OF EMPLOYEES . . . . 58

3-3 SIC GROUPS BY EXPORT CLASSIFICATION . . . . . . 60

3-4 DECISION MAKERS BY JOB TITLE . . . . . . . 62

3-5A AGE OF DECISION MAKERS BY EXPORT CLASSIFICATION • 64

3-5B SUMMARY STATISTICS ON AGE OF DECISION MAKERS • • 64

3-6A EDUCATION OF DECISION MAKERS BY EXPORT CLASSI-

FICATION $\cdot \cdot \cdot \cdot \cdot \cdot \cdot \cdot \cdot \cdot \cdot \cdot \cdot \cdot \cdot \cdot \cdot \cdot \cdot \cdot 65$

3-6B SUMMARY STATISTICS ON EDUCATION OF DECISION

MAKERS $\cdot \cdot \cdot \cdot \cdot \cdot \cdot \cdot \cdot \cdot \cdot \cdot \cdot \cdot \cdot \cdot \cdot \cdot \cdot \cdot \cdot 65$

4-1 RESULTS OF THE KOLMOGOROV-SMIRNOV ANALYSIS . . . 79

5-1 DISCRIMINANT ANALYSIS (ALL VARIABLES AND

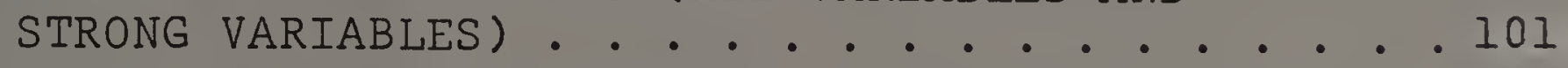

5-2 DISCRIMINANT ANALYSIS (WEAK VARIABLES) . . . . 102 
C H A P T E R I

\section{INTRODUCTION TO THE PROBLEM}

\section{Prolegomenon}

Since 1945, the United States has been the leading economic power of the Western or Free world, and through the fifties, it enjoyed a strong, favorable balance of trade. It alone, of all the major powers, emerged from World War II without any major physical damage to its production and distribution systems. It was the U.S. dollar which, with gold, formed the basis for the international monetary system in the Bretton Woods Agreement. It was the United States with its Marshall Plan that spearheaded the reconstruction of Europe. It was the rise of the U.S. multinational corporation and its spread into developed and underdeveloped countries that gave the United States tremendous economic power throughout the world, even to the point where such critical authors as Servan-Schreiber in American Challenge and Kari Levitt in Silent Surrender pictured the United States as on the brink of dominating the world and reducing practically all of the rest of the countries of the world to second-class status.

However, during the decade of the sixties, the situation began to change. The country's favorable balance of payments was gradually reduced until it became negative. The effect of this change became apparent in the declining 
position of the dollar. Since 1945 it, with gold, had been the standard in international transactions, then, as a result of the deteriorating balance of payments situation, it suffered two devaluations in the early 1970's, and continuing crises threatened further devaluations.

Many factors contributed to this serious reversal in the balance of payments, including the reemergence of Japan and the western European countries as industrial powers, the massive amounts spent by the United States abroad in the form of military and civilian aid, the American multinational corporation with its vast exports of capital and technology all over the globe, and the high rate of inflation in the United States which was triggered by the "guns and butter" policy inaugurated during the Vietnam war.

As the decade of the seventies started, the U.S. government attempted to reverse the negative balance of payments trend but had only limited success. In 1973, spurred on by a devalued dollar, United States exports surged ahead, and it appeared that the battle had been won. Then came the Arab oil embargo with its accompanying runaway oil prices, and once again the value of imports exceeded exports. In the past year the situation has reversed again, but this time American farm products are largely responsible. Bumper grain crops enabled the United States to ship millions of bushels overseas to various countries, especially to the Soviet Union, where bad weather was responsible for serious 
crop failrues. This is not a permanent solution to the problem, however, for agricultural products are subject to the vagaries of the weather, and the indications are that 1976 will be a drought year in which there will be little if any surplus available for export.

Therefore, in order to reverse the balance of payments trend of the early seventies permanently, exports of manufactured products should be increased so that exports continue to exceed imports until the deficit is eliminated, and then trade must maintain an even balance between exports and imports. This can be accomplished by cutting imports, increasing exports, or some combination of the two methods. Since decreasing imports would reduce the standard of living in the United States, it would be politically feasible only as a last resort. Therefore, the most prudent solution would appear to be to increase exports.

Most of the studies in this area have concentrated on the larger firms, and, as a result, the few large companies that have accounted for the bulk of the exports from the United States have tended to overshadow the many small and medium sized firms that also export. It appeared that if a study of smaller businesses could determine why some export and others do not, this information could be used by government and industry change agents to induce small nonexporters to export. Not only would such an increase in exporting help to alleviate the United States' balance of pay- 
ments problem, but it would strengthen the small firms as well. This study is an initial exploration of such small businesses.

Background on International Trade Theories

Mercantilism, the dirst theory of international trade, was developed in Europe in the sixteenth and seventeenth centuries. ${ }^{I}$ Today it would be defined more accurately as "a set of principles and policies for international commerce." 2 During this era many new national states had come into being, the spirit of nationalism was strong, and the welfare of the state was held to be more important than the welfare of the individual. It is important to note that the political and economic leaders, who emphasized these factors, controlled the state since most citizens could not vote and had little public influence. Because internal tax systems were inefficient or non-existent, most of the income for these new nation states came from funds received directly from foreign sources or indirectly from tariffs on imported products.

These emerging European nations needed large armies

${ }^{1}$ Laurence P. Dowd, Principles of World Business (Boston, Massachusetts: Allyn and Bacon, Inc., 1965). This section borrows heavily from Chapter 4, The Theory of International Trade, pp. 69-84.

Ibid., p. 70 
and navies to protect their independence. Since universal military conscription was not yet in vogue, most countries depended on mercenaries, many of them foreign, for their military forces. The demands of the foreign mercenaries for pay in gold or silver forced these countries into a continuing search for precious metals, and this, in turn, gave rise to the mercantile theories or principles.

The fundamental mercantile principle said that in order to grow and remain strong, powerful, and wealthy, a nation consistently had to export more than it imported. The surplus of exports over imports would be paid for in gold, and the nation would be wealthy and secure. To promote exports, the theory held, wages must be kept at the lowest possible levels in order to force the workers to work long hours to survive. Such a system would produce more and cheaper exportable goods. It is interesting to note the effect of this economic necessity on the society. Because this was pre-industrial revolution, manufacturing was labor intensive. This led to the need for a large labor force to make the economic system operate. Out of this need grew moral and religious philosophies that opposed any kind of population control. 3 Another principle of the mercantile theory encouraged savings, not for reinvestment as would be the case today, but for building up stores of gold for the wealthy

${ }^{3 \text { Ibid. }, ~ p . ~} 72$ 
class. This gold acquired because payments received for exports exceeded those paid for imports, was available to the state through voluntary or forced loans and could then be used to pay for necessary military defense.

The mercantilist theories also led the European nations to search for colonies to exploit for the benefit of the homeland. For example, England's mercantile policies of exploiting the American colonies were, to a large extent, responsible for the events which led to the American Revolution.

Largely due to the industrial revolution, world conditions had changed by the end of the eighteenth century, and mercantilism was gradually abandoned. In its place came new ideas about trade, and these are part of what is now called classical economics. Out of classical economics came the concept of comparative advantage which is the basic premise used to explain international trade. David Ricardo is usually given credit for having developed this doctrine ${ }^{4}$ which holds that a nation gains by producing more of those goods in which it is relatively more efficient and by exporting these in return for goods in which its absolute advantage is least. 5

\footnotetext{
${ }^{4}$ Ibid., pp. $69-70$

5 Stefan H. Robock and Kenneth Simmonds, International Business and Multinational Enterprises (Homewood, Illinois: Richard D. Irwin, Inc., 1973), p. 17.
} 
Robinson lists six factors or production inputs which should be considered in any study of comparative advantages. They are:

1. Available natural resources, including arable land.

2. Capital - which is anchored in the ability of a people to produce more goods and services than they consume, past and present.

3. Unskilled labor - that labor requiring very little capital investment other than that needed to keep a person alive at near subsistence level until the age of productive labor.

4. Skilled labor - that labor requiring substantial capital investment in education and training before a return is realized.

5. Entrepreneurship - the psychological set that generated creativity and risk-seeking, which in turn seems to be a function of heightened expectations, assurance of a socially acceptable minimum level of income, and high-level skill of economic value.

6. Government - public services such as law and order, development of a currency system, enforcement of commercial law, maintenance of services including health, education, agricultural extension, and the like - all of which tend to generate an integrated national market and a long-lived, educated population. 6

It can be shown that the principle of comparative advantage works not only where one country has an absolute advantage over another in producing one product but also in the case where one country has an absolute advantage over another country in all products.

${ }^{6}$ Richard D. Robinson, International Business Management (New York: Holt, Rinehart and Winston, Inc., 1973), p. 30 . ${ }^{7}$ Dowd, op. cit., pp. 75-84. 
Theoretically, if the law of comparative advantage were allowed to operate without restrictions, the whole world would benefit. Each country would make those products in which it has a comparative advantage. It would sell its surplus production on the world market and use the income to buy those products in which other countries have a comparative advantage.

While most of the countries of the free world espouse the concept of comparative advantage, many of them limit imports of certain products either through the imposition of quotas or of tariffs. They do this to conserve foreign exchange, to preserve nationalistic pride, to support national defense, to protect certain key industries, to protect jobs in certain areas and to counter unemployment, and so forth.

In what areas does the United States have a comparative advantage? The American industrial machine has prospered as capital has been substituted for unskilled labor in ever increasing amounts, i.e., its high technology industries. Today, as a result, the United States generally possesses a comparative advantage in goods which are relatively rich in resources, skilled labor, entrepreneurship, and government services. These in turn are a function, at least in part, of the relative capital wealth of the United States for many years. ${ }^{8}$

${ }^{8}$ Robinson, op. cit., pp. $31-32$. 
As U.S. industrial firms grew larger, it became obvious that there were certain advantages in opening production facilities in other areas of the world. The reasons might be to obtain raw materials, such as oil or ores of various kinds, or to grow products unsuitable to the climate of the homeland, such as sugar cane or bananas, or to open production facilities in markets which were closed to exports from the homeland because of comparative cost disadvantages, tariff walls, or impont restrictions.

The use of foreign production facilities had been going on for years on a small scale, but following the second world war, the growth mushroomed. The leaders were the large American corporations, and by the middle of the sixties the American multinationals dominated the world's industrial scene, thus adding a new dimension to international business. They expanded very rapidly, and soon many of the major markets of the world were being supplied by "American" goods, goods made not in the United States but in one of many American-owned plants abroad.

International trade differs from domestic trade in one very important respect. The buyers and sellers, whether they are multinationals or small exporters and importers, are operating across international boundaries with different currencies in use on either side of these boundaries. These currencies may be readily exchanged for each other, or they may not. It is unlikely that in any given period the trade 
between two countries will be exactly even, i.e., that country A will buy exactly the same amount from country B that it exports to $B$. The balance of payments between nations has been traditionally made in gold or in one of the world's strong currencies because there have been no truly international currencies. Prior to World War I the pound sterling was the currency of international trade. However, after the drain on Great Britain's economic resources during the first World War, the pound began to decline until by 1945 its importance and prestige in international transactions has waned. 9

The vacuum left by the decline of the pound and by the general world-wide chaos caused by World War II was filled in 1944 with the signing of the Bretton Woods Agreement. Among other things, this created the International Monetary Fund (IMF). "The IMF regulates and coordinates overall international financial relations."10 Its objectives as defined in the Bretton Woods Agreement are:

- promotion of exchange-rate stability

- maintenance of orderly exchange arrangements

- avoidance of competitive currency depreciation

- establishment of a multilateral system of payments and the elimination of exchange restrictions

\footnotetext{
9owd, op. cit., p. 103

${ }^{10}$ Endel J. Kolde, International Business Enterprise (Englewood Cliffs, New Jersey: Prentice-Hall, Inc., 1968), p. 143 .
} 
- creation of a stand-by source of exchange reserves available to individual countries in case of maladjustments in international payments.l1

The fund used gold and the dollar convertible into gold at a fixed price of $\$ 35.00$ an ounce as the basis of the international exchange of member currencies. The system worked well through the world wide reconstruction period of the late forties and the fifties.

The Current Problem

The dollar which has been the basis for the post-war economic recovery began to falter as European and Japanese economies flourished in the economic boom of the sixties. The dollar, with its value pegged at a fixed level in terms of gold, did not have the flexibility of the other major world currencies. In 1971 Peter G. Peterson, Assistant to the President for International Affairs, noted, as he looked back on this turbulent era, that it was the dollar which had kept the international exchange system operating. Since the Bretton Woods Agreement in 1944, the United States had assumed the role of surrogate central banker for the world and had kept the system going as long as it did only because it was willing to incur both the perennial balance of payments deficits and the increasing world liabilities and declining currency reserves that resulted from these deficits.

${ }^{11}$ Ibid., p. 148 
The problems arose because these deficits, which were financed in effect by loans from the various foreign central banks, caused the foreign bankers to lose confidence in the dollar and to charge that the United States was exporting inflation by autonomously increasing the world's money supply. The Bretton Woods Agreement contained no corrective measures other than drastic deflation which the United States was unwilling to impose on its citizens and which would have been self-defeating in any case, since the U.S. balance of payments deficits were the main source of international liquidity. 12

The International Monetary Fund defines a country's balance of payments as "a systematic record of the economic transactions during a given period between its residents and residents of the rest of the world."13 As the sixties wore on, the United States began to have a negative balance of payments. There were many reasons for this. The billions spent for foreign aid, both military and non-military, the money spent by the multinational corporations on overseas expansion, and the insatiable appetite of the United States for foreign consumer products, industrial goods, and raw materials were all partially responsible.

${ }^{12}$ Peter G. Peterson, The United States in the Changing World Economy (London, England: British-North American Research Association, 1972), pp. 17-18.

13 International Monetary Fund, Balance of Payments Concepts and Definitions (Washington, D.C.: International Monetary Fund, Pamphlet Series No. 10, 1968), p. 4. 
The balance of payments crisis led to the imposition of monetary controls in the late sixties. This limited the export of funds for the expansion of U.S. facilities abroad and forced the multinationals to go to the money markets of Europe and Japan for their capital needs. The trade deficits continued, and in the early 1970's a series of dollar crises forced two devaluations of the dollar.

This led to a reevaluation of American economic policies and a call for more exporting. The Bureau of International Commerce of the U.S. Department of Commerce began an advertising campaign in August of 1971 with the aim of promoting export business by United States firms. Late in 1971 a survey conducted for the Commerce Department by the Opinion Research Corporation polled 788 companies, 508 exporters and 280 non-exporters. It found that only 5 percent of the exporters, who were aware of the advertising, could recall the two themes, "easier to trade with foreign countries" and "telling about the services available."14 The survey concluded that the Bureau of Interantional Commerce's promotional campaign appeared to have had little significant effect in generating a positive shift in attitudes towards exporting,

14 "Businessmen's Awareness and Attitudes Toward Exporting and Exporting Promotional Efforts, Phase II, "Report to the Bureau of International Commerce of the U.S. Department of Commerce (Princeton, New Jersey: Opinion Research Corporation, 1972), p. 26 . 
or increasing knowledge about exporting, awareness of, and use of BIC's service or awareness of advertising to promote exporting. 15

The United States is the world's leading industrial producer and, as such, is also the world's leading exporter in value of total exports, but exporting is relatively much less important to American industry than it is to any of the other leading industrial nations of the free world. Consider these paradoxical statistics.

- Less than ten percent of U.S. manufacturers export any of their products.

- Those who do, do so on a marginal basis.

- The United States exports less than five percent of its total production.

- Among major competitor nations up to twenty percent of total production is exported.16

To a certain extent these figures are understandable. The United States has a huge domestic market, and many U.S. companies can do all of the business they want without exporting. This is not so in other highly industrialized areas of the world. In Europe, especially, the Common Market has promoted exports among its members. Another factor, of course, has been the growth of the U.S. multinational corporation. By maintaining production facilities in strategic areas around the globe, exports of finished products from the

$$
\begin{aligned}
& { }^{15} \text { Ibid., p. iv. } \\
& { }^{16} \text { Ibid. , p. i. }
\end{aligned}
$$


United States have been drastically curtailed.

United States exports are dominated by the large corporations. The twenty-five largest exporters account for seventy-five percent of the country's exports. ${ }^{17}$ This means that there should be ample room for small and medium sized firms to increase their exports and thus hlep the U.S. balance-of-payments problems.

In 1968 James Pinney ${ }^{18}$ found that although numerous studies had been made on various aspects of international business, they tended to stress the problems and the opportunities of the multinational and, with a few minor exceptions, ignored those of small business. A review of the literature since that time has found very little additional material pertaining to the exports of small business. One exception, a doctoral dissertation by Claude L. Simpson Jr. ${ }^{19}$ will be discussed later. The Opinion Research Corporation Survey, quoted earlier, gives some hints as to the place of small business in the export field, but the survey itself used a sample of firms of all sizes. Therefore, all available literature is surveyed here, but where possible an

17 "Eximbank's Full Service for Exporters," Industry Week, Vol. 174, No. 11 (Sept. 11, 1972), p. 46.

18 James K. Pinney, "The Process of Commitment to Foreign Trade: Selected Smaller Indiana Manufacturing Firms" (unpublished DBA dissertation, Indiana University Graduate School of Business, 1968).

${ }^{19}$ Claude L. Simpson, Jr., "The Export Decision Process: An Interview Study of the Decision Process in Tennessee Manufacturing Firms" (unpublished PhD dissertation, Georgia State University - School of Business Administration, 1973). 
attempt is made to interpret it as it applies to smaller firms.

If the United States exports are to increase, it would appear that the problem should be attacked on two fronts. The first would be to persuade present exporters to export more, and the second would be to induce more manufacturers to export. However, before government officials can do much to solve the second problem, they must understand the reasons why companies do not export.

Henry Kearns, former president and chairman of the Export-Import Bank, believes that the reasons more American firms do not export are that they feel the domestic market is so big that there is no reason to go outside the United States. In addition, they believe that American goods are priced out of the export market. 20 "There is also a kind of provincial feeling on the part of American business that international trade is too complex, too difficult, too hazardous - it's a sort of mysterious thing you don't want to mess with." 21

Two-hundred Fifty-four firms whose exports were less than five percent of their sales volume gave the following answers to the question of why they did not export a greater percentage of their sales volume.

20 "Eximbank's Full Service for Exporters," op. cit., pp. $49-50$. p. 50 .

\footnotetext{
"Eximbank's Full Service for Exporters," op. cit.,
} 
$\underline{\text { Reason Given }}$

Cannot compete/our prices are too high

$22 \%$

Do not actively sell or solicit business abroad 20

No demand for our products or services abroad 18

Too costly to export/shipping costs are too high 14

Do not have an export representative

Have enough domestic business now

Our company is too small

Other answers

Don't know

In a comparative study of Scandinavian and American exporters, all employing less than a thousand workers, it was found that both the American and Scandinavian firms found inadequate representation and competitive pricing were common problems. In addition the American companies found the intricate documentation required for exporting and granting credit were serious problems. The Scandinavian firms found neither of these to be a problem. The latter two problems probably reflect the difference in export experience between the Scandinavian and American companies. Several American firms, although they felt credit was a problem, were unaware that credit insurance had been available for two years. ${ }^{23}$ Why do some firms export while others do not? Pinney based his work on Rogers' studies in the area of the diffu-

22 "Businessmen's Awareness and Attitudes Toward Exporting and Exporting Promotional Efforts, Phase II," op. cit., p. 21 .

23 Lester Allan NeidelI, "U.S. and Scandinavian Export Practices Compared," New England Business Review, September $1965, \mathrm{P} .12$. 
sion of innovation. ${ }^{24}$ Rogers describes innovation as an idea perceived as new to the individual and notes that it is not important to the individual's behavior whether the idea is actually new. ${ }^{25}$ In his study of seven small and medium sized Indiana firms which were already committed to foreign trade, Pinney regards exporting as the innovation under consideration. He then develops a set of necessary and sufficient conditions which must be met before a firm can become engaged in and successfully committed to foreign trade. ${ }^{26}$ As Pinney himself recognizes, 27 these findings are based on very tenuous grounds. Seven firms is a very small sample from which to make any generalization to a larger population. However, it was one of the few research projects found that dealt with the reasons why a small company exports.

An earlier study, (1965), 28 of the characteristics of Michigan exporters, defines a modal firm which, although not existing in fact, is representative of the most commonly encountered exporter. The modal firm has an employment of 497 persons and high productivity with annual shipments of $\$ 20,000$ per employee. The report concludes that the modal firm is

${ }^{24}$ Everett M. Rogers, Diffusion of Innovation (New York: The Free Press, 1962).

25 Ibid., p. 13.

26 Pinney, op. cit., pp. xiv-xv.

27 Pinney, op.cit., p. 340 .

${ }^{28} \mathrm{John}$ L. Hazard, Michigan's Commerce and Commercial Policy Study (East Lansing, Michigan: MSU International Business Studies, 1965 ), p. 70 . 
larger and more productive than the average Michigan firm. Although he had only limited evidence, Pinney seemed to feel this was also true of the companies he studied.

The Opinion Research survey also indicates that the smaller firm appears to be less committed than is the larger firm. Of the 776 companies in this survey, the mean number of employees of the 523 companies that did some exporting was 1538 , while for the 253 companies that did no exporting, it was 301 . The average sales for the exporting companies was $\$ 42.6$ million and for the non-exporting companies it was $\$ 11.1$ million. Once again this indicates that the smaller firm is less committed to export trade than is the larger one. 29

Simpson ${ }^{30}$ in a study of the profiles of fifty exporters and of seventy non-exporters found that although both groups received similar stimuli such as an unsolicited export order, these stimuli were a significant but not sufficient condition to induce them to export. Instead he found that the decision to export may well be due to the perceptions of the decision makers with regard to risks and cost/benefit tradeoffs.

The reasons firms give for not exporting imply, among other things, that they feel they lack the expertise to handle

29"Businessmen's Awareness and Attitudes Toward Exporting and Exporting Promotional Efforts, Phase II," op. cit., pp. $59-61$. ${ }^{30}$ Simpson, op. cit., pp. $39-41$. 
the complexities of expont business. This may be so, but there is help available. The U.S. Department of Commerce has forty-three district cffices located all over the United States, and they are staffed with trade experts ready to help any business, large or small. However, since most of the corcorate giarts have complete staffs of their own, the commerce Department works chiefly with small and medium sized business. In $\equiv$ pamphlet outlinirg its services, the department has this to say about the government's economic objective and the place of intencticnal trade in accomplishing this objective.

The Dasic economic objective of the U.S. Government is an expanded, more dynamic and productive national econony that will strengthen our nation at home and abroad; provide full employment; and raise the Americar. stardard of living to higher levels.

Expanced international trade - expecially an increase in U.S. exports - is one of the most important ways in wich this objective can be attained. 3

The Department of Commerce publishes a vast amount of material covering almost all areas of intennational business. Its economic reports on various countries are often superior to anything published in that country and so are used by $10-$ cal as well as American firms. Most of the services are free, but rominal charges are made for some specialized services aric fublications.

$H \in l p$ is available in other areas also. In March of 1973 tre horld Trade Institute and the Vational Association of partment cé Commerce Publication, Revised May 1973. 
Manufacturers held the first workshop under a new program called "Partners-In-Trade." In this program "twenty-five large firms experienced in foreign trade assist smaller companies to start or expand their export efforts." 32 Thirtyseven companies participated in the first seminar. This was slightly less than anticipated, but the response of the participants was very good. Only about half of them had any previous experience in overseas markets before joining "Partners-In-Trade," and most of this experience was very limited. However, since the seminar about seventy-five percent of the companies have sold in markets where they have not participated before. ${ }^{3} 3 \mathrm{Dr}$. Zwick, Director of the World Trade Institute, was very pleased with the results and planned to expand the program to four or five more cities in 1974 . He felt more companies would have participated if business conditions in the United States had not been so good. 34 There are other agencies that also help. In Boston there is the International Center of New England, Inc., a non-profit organization which promotes export business for New England firms. It sponsors a number of conferences during the year for manufacturers from New England and also main-

32 "Small Firms to Get Boost Into Exporting from Giants," Commerce Today, Vol. 3, No. 9 (February 5, 1973), p. 38 . 33"Small Firms Find 'Partners' Program Helps Export Sales," Industry Week, Vol. 178, No. 8 (August 20, 1973), pp. $10-12$

${ }^{34}$ Ibid., pp. 10-12. 
tains a library of international publications. Trade Associations of various sorts may also provide help, (as previously noted, NAM was a co-sponsor of the "Partners-In-Trade" program), but this will depend to a large extent on the particular association. Some of the State Universities are also providing seminars in international marketing. The University of Massachusetts is one of these.

Interestingly enough, as Pinney pointed out, the textbooks generally bypass the area of exporting for the small firm. The international management and marketing texts deal primarily with the multinational corporations while the books on small business generally omit any discussion of export business. One good book, which unfortunately is out of print, is Strategic Planning for Export Marketing by Franklin R. Root. ${ }^{35}$ The Small Business Administration has published a small book, Export Marketing for Smaller Firms. ${ }^{36}$ Now in its third edition, this book was prepared by the International Marketing Institute of Cambridge, Massachusetts. It is intended to provide a step by step procedure which any ownermanager of a small business can follow in order to assess the export market potential for his product, and the steps he needs to follow in order to assess the export market potential for his product, and the steps he needs to follow if he

${ }^{35}$ Franklin Root, Strategic Planning for Export Marketing (Scranton, Pennsylvania: International Textbook Co., 1966).

${ }^{36}$ Export Marketing for Smaller Firms (3rd edition; Washington, D.C.: Small Business Administration, 1971). 
then decides to export.

Two other books of the "cookbook" variety were found. These were both Canadian. The first, published in 1967, is a compilation of articles which appeared in the Canadian Department of Trade and Commerce's publication Foreign Trade. The book is entitled How to Win World Markets. ${ }^{37}$ The International Trade Centre in Geneva was so impressed with the book that it persuaded the Canadian Department of Trade to publish a revised edition geared to the under-developed countries. This was published in 1970 under the title Getting Started in Export Trade. ${ }^{38}$ Both books are excellent for the novice in exporting. In a very non-technical way they lead him through the steps necessary to enter the export market.

The Revenue Act of 1971 authorized American companies to form Domestic International Sales Corporations (DISCs). A DISC can be set up by any corporation as long as it complies with the restrictions of the law. Under the law the DISC pays no income tax, but the shareholder (the parent corporation) pays taxes on fifty percent of the DISC's earnings. No tax is paid on the remainder until it is distributed to the stockholder. The aim of the law is to help do-

${ }^{37} 0$. Mary Hill, ed., How To Win World Markets (Ottawa, Canada: Department of Trade and Commerce, 1967).

${ }^{38}$ Getting Started In Export Trade (Geneva, Switzerland: International Trade Centre, 1970). 
mestic companies to compete on equal terms with many foreign exponters. One study ${ }^{39}$ showed that annual sales of $\$ 50,000$ were needed to break even on a DISC. Thus it appears that although a DISC can be helpful to a company that is already exporting, it is doubtful that it would stimulate many small companies to begin exporting.

A number of attempts by both governmental and private agencies to promote exporting have been cited. Unfortunately none of these has accomplished its goal. Since the methods chosen have failed to stimulate exports to the desired levels, it appears that further study is needed to discover the reasons companies do or do not export. The next section will discuss these research needs in more detail.

\section{Statement of Research Needs}

Since the end of the 1950's, the United States has experienced a deteriorating balance of payments situation. This forced two dollar devaluations in the early 1970's. For a time the devaluations appeared to solve the balance of payments problem, only to see it reappear again during the energy crisis of 1973-74. The forecasted long term energy crisis, including the rise of the OPEC oil cartel, and this country's heavy commitment to the defense of the "free world" have insured that this balance of payments problem 
will not fade into the background. If the United States is to continue as a world leader, and if its citizens are not going to suffer severe cuts in their standard of living, 40 then the United States must increase its exports substantially. The government realizes this and has taken the following steps to accomplish it.

1. It is sponsoring a continuing advertising campaign to convince U.S. businessmen of the value of exporting.

2. The regional Department of Commerce offices have stepped up their promotion of export business, and the department has increased the variety of published material available to help prospective exporters.

3. Government sponsored insurance is available to protect against commercial and political risks abroad.

4. Qualified exporters can form Domestic International Sales Corporations, (DISC) to handle exports and to indefinitely defer taxes on income earned by these corporations.

In addition, although published figures are not available, it appears that the profits of firms which regularly

40 While many Americans would argue that the United States must reduce its standard of living, it should be understood that this would have severe political repercussions. The decisions on the moral and ethical issues involved are outside the scope of this study. 
export a portion of their output are at least as great on their export business as on their domestic business.

The United States exports between four and five percent of its production annually, and this figure has remained relatively static for several years. Earlier it was pointed out that small and medium sized firms are less apt to export than are large firms, so it would be expected that small and medium sized firms export considerably less than four percent of their total production. The question which should be asked is, "Why?" It would appear that the incentives offered by the government and the prospects for at least average and probably better than average profits have had little effect. In other words, more than economic reasons are involved. In the past the exports of the United States have been dominated by the country's huge firms, and consequently most of the attempts to increase exports have been aimed at the large firms. However, the country's smaller firms, when considered as a group, could help tremendously in the balance of payments problem if those already exporting could be persuaded to export more, and those not now exporting could be persuaded to begin exporting. This study is concerned with the non-exporters and is an attempt to identify basic differences between the decision makers in exporting and non-exporting companies.

The Commonwealth of Massachusetts, along with the other New England states, has its own special problems. As a 
mature region, it must gradually replace its lagging industries with new, high technology industries. ${ }^{41}$ These companies, at least in the beginning, tend to be small, but they also tend to be the type of companies in which the United States has a comparative advantage, i.e., their products are relatively rich in resources, capital, skilled labor, and entrepreneurship. Therefore, if Massachusetts is to grow and prosper, it must attract more of these high technology industries and also provide an industrial climate in which those it has now can grow and prosper. As this country's domestic markets become increasingly competitive, exporting becomes a more interesting alternative for these Massachusetts' manufacturers. In addition, the state's location, although it may be a disadvantage in shipments to some parts of the United States, is ideal for shipments to Europe and to certain other areas of the world.

In the past, attempts to increase exports have met with very limited success. If a manufacturer is interested in exporting, then the U.S. Department of Commerce has a tremendous amount of material available to him, either at no cost or else at a very nominal price. However, attempts by the department to advertise its program have, as stated, met with very little success, either in gaining new users of its services or even in awareness that these services are avail-

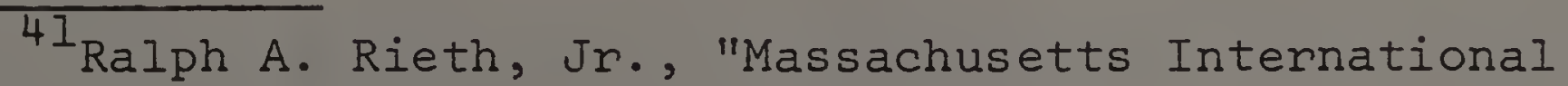
Position," unpublished report. 
able. Practically no studies have been made to find out why some manufacturers are very active in exporting, while others in another situation, with the same or a very similar product, will not export. Simpson, 42 in his study of small and medium sized Tennessee firms, found that one cause may be the difference in the perceived risks, profits, and costs between exporters and non-exporters. It appeared that this might be a very valid reason and one that deserved further study. If such a study should confirm simpson's preliminary findings, then educational programs could be devised by state or federal officials to help change the perceptions which hinder exporting. Simpson also found that the decision makers in the exporting firms had a higher amount of formal education than did those in the non-exporting firms. Interestingly enough, he found no statistical difference between the foreign travel of the decision makers of the two groups. Both of these factors appeared worthy of further study with the idea that knowledge of the results could help government officials in dealing with the problem.

In a small company, the decision of whether or not to export usually rests in the hands of one person. He may be the marketing department, but, more likely, he holds a top management position and often is the chief executive of the company. Simpson's study showed that the initial export de-

${ }^{42}$ Simpson, op. cit., pp. 103-106. 
cision usually came as the result of an unsolicited inquiry from abroad. He also found that the non-exporting companies received almost as many unsolicited inquiries as did the ex-. porters. Although such an inquiry may provide the impetus to start a company exporting, it apparently will not overcome other strong perceptions about the problems involved in exporting. Therefore, this study examines the perceptions of the executives who are responsible for deciding whether or not to export.

One way to view exporting is as a product which the federal and state governments are trying to "sell" to a sometimes eager, sometimes indifferent, and sometimes reluctant manufacturer. The success the government has is dependent to a large extent on the buyer's perception of the product (exporting). In this context then, a management problem is restructured into a problem of buyer behavior, where the researcher's problem is to determine the decision maker's perception of exporting. This is the approach used in this study

Value of the Research

For many years the United States, in its romance with growth, has downplayed the importance of the smaller firm in international business. As a result there is little information available on the reasons why small businesses export or do not export. This means that in times such as the 
present when government policy calls for increased exports and when the methods used to promote exports fail to produce the desired results, there is no research to fall back on to determine why. This exploratory study gives some insight into the problem. If further research confirms the findings, it might indicate to government officials that a change in strategy is necessary in order to make the government export policy effective. Various trade associations and non-profit corporations may also be interested in the results because a number of them are also interested in promoting exports. The work of the International Center of New England, Inc., The World Trade Institute, and the National Association of Manufacturers were discussed earlier.

Although this study is aimed at the small manufacturer, the results should also be applicable to the decision makers in medium sized and possibly in large firms as well. If so, this study could be even more valuable in increasing exports. The academic community is another area that might benefit from this study. If business students were exposed to the results of the study, it might give them a better insight into the problems they may face after they graduate and so improve their training for a business career. This information could also be disseminated to businessmen through seminars and workshops. Finally, as an exploratory study, it provides a base from which further academic research can be done. 
Organization of the Report

This study has been organized into six chapters and will attempt to report the research in a systematic and logical manner. The first chapter introduced the problem, reviewed the pertinent literature, and gave a brief history of international trade theory. Chapter II will describe the scope of the study, present the hypotheses to be tested, and describe the research design and the statistical analyses to be used.

Chapter III will review the actual field research and discuss the various problems that were encountered. It will look at the three general groups of firms (committed exporters, non-committed exporters, and non-exporters) uncovered by the study and will discuss their similarities and their differences. A profile of the executives responsible for deciding whether or not their companies export will be drawn. The reasons given by the exporters for entering the export market and the reasons given by the non-exporters for not exporting will be examined, and finally the study will look at the principal benefits that the exporters have found as a result of exporting as well as the main problems they have encountered.

The fourth chapter will look at the Kolmogorov-Sminnov nonparametric analysis of the results. Because of the appearance of two classes of exporters (committed and non-com- 
mitted), two sets of tests will be run. The first will compare all exporters with all non-exporters, and the second will compare the committed exporters with the non-committed exporters and the non-exporters. Each statement that is statistically significant at the .10 level or better will be discussed and the results will be analyzed. The limitations of the analysis due to the sample size will be discussed. Finally, all non-significant statements will be listed.

Chapter $V$ will present the results of the multivariate analysis. The unusual and unexpected results of the factor analysis will be discussed, including a discussion of the various methods that were used to try and improve the results. The discriminant analysis will be examined in some detail, and the various steps used to test the hypothesis and the final conclusions will be discussed.

The sixth chapter will review the general findings, including a discussion of the limitations of the research. It will also discuss implications for public policy and changes that might be suggested in the policy as a result of the study. The last section will talk about future research that has been suggested as a result of this research. 
C H A P T E R II

RESEARCH METHODOLOGY

Scope

Why do some small manufacturers export while other

small manufacturers with very similar product lines do not? This is the general question introduced in Chapter I. There are a number of possible approaches to the problem. One would be to study secondary data. The Bureau of the Census and the United States Department of Commerce publish numerous statistics covering many facets of business activities, and perhaps some useful information might be gleaned from these sources. A second possibility is to talk to the government officials who are responsible for trying to increase exports to find out the reasons they have been unsuccessful in increasing exports at the desired rate. A thind method would be to conduct a survey of small manufacturers and ask them direct questions about why they do or do not export.

All three of these approaches were considered for this study, but none of them answers the question posed at the end of Chapter I. Do exporters and non-exporters differ in their perceptions of certain key factors involved in exporting? Governmental and private statistics provide a wealth of information about exporters and non-exporters, but this information is factual in nature, i.e. value of production, 
value of exports, exports as a percent of total sales, payroll, number of employees, and so forth. While such figures help to provide a picture of the companies, they do not help to answer the subjective questions posed by this study. Government officials have been trying, unsuccessfully for the most part, to convince more companies to export. If they were aware of new approaches to this problem, one would expect that they would already be using them. Talks with government officials confirmed the fact that their proposed solutions seemed, for the most part, to be the same general types of solutions that have not worked in the past. Asking decision makers why they do or do not export will probably not produce useful answers if the reason has to do with the decision makers' perception of the problem. This is because studies by psychologists have shown that few people can report attitudes or perceptions correctly when faced with direct questions. ${ }^{I}$ Therefore some method other than using secondary data, discussing the problem with government officials, or asking direct questions of company executives should be used. The research approach chosen for this investigation is discussed later in this chapter.

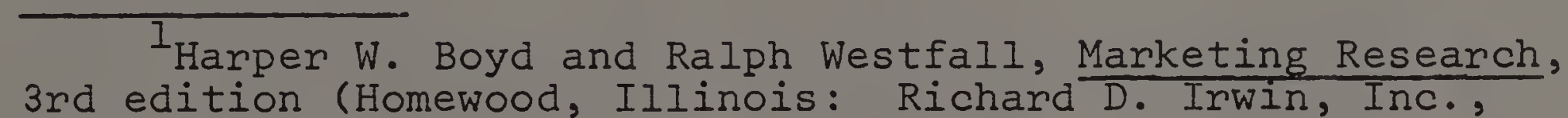
$1972)$, p. 317 . 
Hypotheses

This study does not present a series of hypotheses and test them for statistical significance as is often done in research of this type. Instead it has one major and two minor hypotheses. The major hypothesis is:

The perceptions of the decision makers of firms engaged in exporting toward such factors of exporting as risk, profit potential, costs, problems, and personal rewards differ from the perceptions toward these factors of the decision makers of firms not engaged in exporting.

The null hypothesis to be tested is that:

There is, in fact, no difference in the perceptions of exporters and non-exporters toward such factors of exporting as risk, profit potential, costs, problems, and personal rewards.

In addition, two minor hypotheses will be tested. Simpson ${ }^{2}$ found a statistically significant difference between the educational level of exporters and non-exporters. If further research should confirm this, then perhaps educational level might be one factor that influences perceptions

${ }^{2}$ Claude L. Simpson, Jr., "The Export Decision Process: An Interview Study of the Decision Process in Tennessee Manufacturing Firms," (unpublished PhD dissertation, Georgia State University - School of Business Administration, 1973), p. 64 . 
of exporting. Pinney ${ }^{3}$ found that foreign travel was one of a number of necessary and sufficient conditions needed before a firm could be successfully committed to foreign trade. Simpson, ${ }^{4}$ on the other hand, found no statistical difference in the foreign travel of exporters and non-exporters. As far as could be determined, no other tests had been made in these areas. Since the study is intended to find out some of the reasons companies do or do not export, it would appear beneficial to either confirm or reject these earlier findings. In addition, if either of these were supported, it might give some indication of the source of the perceptions toward exporting of the major hypothesis. The two minor hypotheses to be tested are:

1 The decision makers of firms engaged in exporting have had more years of formal schooling than have the decision makers of firms not engaged in exporting.

2

More decision makers of firms engaged in exporting have traveled to foreign countries than have the decision makers of firms not engaged in exporting.

${ }^{3}$ James K. Pinney, "The Process of Commitment to Foreign Trade: Selected Smalier Indiana Manufacturing Firms," (unpublished DBA dissertation, Indiana University Graduate School of Business, 1968), p. 328 .

${ }^{4}$ Simpson, op. cit., p. 62 . 
In both cases the null hypothesis to be tested is that there is, in fact, no difference between the two groups. Both of these minor hypotheses will be tested using a student t-test.

\section{Operational Definitions}

For the purposes of this study the following definitions will apply.

1. Decision maker - This is the person responsible for making the decision to export or not to export. In larger firms this would probably the marketing vicepresident or the marketing manager, but in the small companies used in this survey, it is usually a corporate officer and often the president.

2. Product - McCarthy defines product as "the capacity to provide the statisfaction, use or perhaps the profit desired by the customer." 5 It is in this sense that exporting is considered a product. The change agents in government must convince the decision makers that exporting can provide profits for the firm and advancement and/or personal satisfaction for the decision maker.

3. Change agent - "A professional person who attempts to influence adoption decisions in a direction he feels

${ }^{5}$ E. Jerome McCarthy, Basic Marketing, 5th edition (Homewood, Illinois: Richard D. Irwin, Inc., 1975), p. 228 
desirable."6

4. Exporter - A manufacturing company which sells its produst in countries other than the United States. For purposes of this study, the company must be currently selling in the export market to be considered an exporter.

5. Non-exporter - A manufacturing company which is currently selling its products only in the United States. Companies which have previously exported, but which are not doing so now, will be classified as non-exporters.

6. Perception - "The process through which we gain meaning from the parts of the universe to which we pay attention by organizing and interpreting the evidence brought to us by our senses." 7

7. Committed Exporter - An exporter whose management has decided that the export market offers sufficient potential so that a certain percentage of the company's efforts should be directed toward expanding this export market.

8. Non-Committed Exporter - An unwilling or reluctant exporter whose management would much prefer to sell only

${ }^{6}$ Everett Rogers, Diffusion of Innovations (New York: The Free Press, 1962), P. 254.

${ }^{7}$ Chester R. Wasson, Consumer Behavior, A Managerial Viewpoint (Austin, Texas: Austin Educational Division of Lone Star Publishers, Inc., 1975), p. 125. 
in the domestic market and who is only exporting due to some unusual circumstances such as pressure from a large American customer to ship to one of their overseas subsidiaries.

\section{Research Design}

Although an increasingly unfavorable balance of payments situation in the early seventies made U.S. government officials aware of the need to increase overseas shipments, their efforts to stimulate exports have met with only moderate success. There is some indication that part of the problem occurs because exporters and non-exporters do not have the same perceptions toward the risks, profit potentials, costs, problems, and personal rewards of exporting. The approach chosen for this study is to view it as a buyer behavior problem and to study the perception toward exporting of the decision makers of exporting and non-exporting companies.

An indirect approach is called for since few people can report attitudes and perceptions accurately when faced with direct questions. Social psychologists have developed a number of rating scales to test attitudes. For this study there are three criteria that the scale must meet. First, it must be a good measurement of perception. Second, it must be easily understood by the person taking the test. Third, it must be reasonably fast to administer, since it is to be given to a busy executive whose time is valuable. Therefore, 
ease of understanding the scale used and speed in taking the test are important. There are a number of possible scales that might be used. Among them are the Thurstone scale, the semantic differential, the Likert scale, and the Guttman scale. A Likert type scale was chosen for this study for the following reasons. First, it is well suited to measure perception. Second, it is very commonly used so that most people are familiar with it and feel comfortable using it. Third, since most people are familiar with it, the test is easy to administer, and there are fewer chances of the respondent making errors that would nullify the results. Fourth, it is quicker to take than tests using some of the other scales.

In the Likert type scale, ${ }^{8}$ the respondent is asked to read a number of statements and to rate them on a five to seven point scale indicating his degree of agreement or disagreement with the statement. Since the scale is well suited to measure perception, it has been adopted for this study. Forty-nine statements ${ }^{9}$ have been developed to measure the respondent's perceptions of the risks, profit po-

${ }^{8}$ Paul E. Green and Donald S. Tull, Research for Marketing Decisions, 2nd edition (Englewood Cliffs, New Jersey: Prentice-Hall, Inc., 1970), Pp. 174-205. ${ }^{9}$ Copy of the form OPINIONS OF EXPORTING is in Appendix A. 
tentials, costs, problems, and personal rewards of exporting. ${ }^{10}$ Each of the decision makers is asked to rate the statement on a six point likert type scale from strongly disagree to strongly agree, and the results will be analyzed to determine whether the exporter and non-exporters differ significantly in their responses.

Since the economic prosperity of Massachusetts is dependent on the increase and expansion of its high technology growth industries, ${ }^{11}$ this study is designed to deal specifically with this group ${ }^{12}$ and is limited to small firms employing twenty to five-hundred people. The lower limit is used because it is felt that firms with fewer than twenty employees will generally lack the resources necessary to undertake an effective export program, while five-hundred is the upper limit for the small firm category used in many government statistics.

The research design calls for a convenience sample of

10 The statements and the other research instruments were pretested in July 1975 using a sample of seven small New Hampshire manufacturers. The pretest uncovered some problems with the statements about the perceptions of exporting. Some were ambiguous while others were actually double statements so that a person might agree with one part of the statement and disagree with the other. All of those that were found were either changed to eliminate the problem or were omitted from the statements that were actually used in the research. In addition, the pretest pinpointed a few changes that needed to be made in the programmed interview.

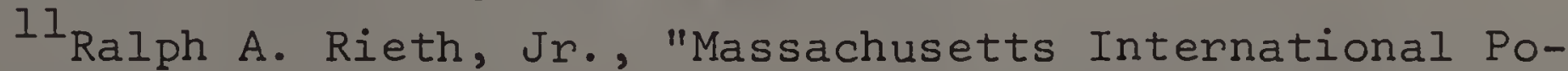
sition," unpublished report.

12 This was later expanded to include SIC Group 34, (Fabricated Metal Products except Machinery and Transportation Equipment). 
twenty-five exporters and twenty-five non-exporters. ${ }^{13}$ The two samples are to be matched as closely as possible for both size and product line. ${ }^{14}$ A convenience sample is a non-random or non-probability sample chosen "purely on the basis of convenience." 15 It is chosen over the technically better random sample for the following reasons. A random sample would require a complete list of all possible firms divided into two groups (exporters and non-exporters). The state industrial directory lists the firms but does not tell whether they export. Therefore, if a random sample were to be used, a survey of all companies would have to be conducted to find out those that export. This would add a great deal of expense to the survey. In addition, if this were done and if the firms were selected by some random method, not all of them would agree to participate. This means that replacements for these companies would have to be selected, and even if a random selection process were used, the randomness of the sample would be suspect. In addition, it is absolutely essential that the decision makers of the firms involved be willing to cooperate in the research. This means that the researcher should be able to drop firms from the study, if, after the initial telephone

${ }^{13}$ The final sample contained 34 exporters and 25 nonexporters for reasons which are explained in Chapter III.

14 This later proved impractical to carry out.

${ }^{15}$ Boyd and Westfall, op. cit., p. 422 . 
contact, it is obvious that they do not meet the criteria of the study, or if they indicate that they will not cooperate to the extent necessary to complete the study. Since the study is exploratory in nature, cooperation is a more important factor than randomness.

Each of the firms selected was visited, and the decision maker who is responsible for deciding whether or not the firm will export was interviewed. A programmed interview $^{16}$ was used to give the interviewer a picture of the firm and of its decision maker. ${ }^{17}$ At the close of the interview, each decision maker was asked to fill out the sheets "Opinions of Exporting" which contain the forty-nine statements about exporting. ${ }^{18}$ This information will be summarized later in the study. In addition, the information about the education and the foreign travel of the decision makers will be used in the statistical analyses to test the two minor hypotheses.

${ }^{16}$ Also known as patterned or structured interview. 17 Copy of the programmed interview form is in Appendix B. 18 When this research was planned, it was assumed that two distinct groups would appear, i.e., exporters and non-exporters. However, as the interviews progressed, a few of the exporters appeared to have many of the characteristics of the non-exporters even though they did some limited exporting. In most cases they exported reluctantly, usually at the behest of one of their large customers who had overseas branches or overseas customers he wanted them to ship to. Generally, but not always, their exports were limited to one or two customers. Seven of these were discovered, and they were labeled as noncommitted exporters while the balance of the exporters, who actively pursued export business, were called committed exporters. 
The Statistical Analysis

The major focus of the study is contained in the analysis of the "Opinions of Exporting." Traditionally data obtained on a Likert scale has been considered as having ordinal rank. As a result statistical tests which require interval or ratio data are inappropriate. However, certain nonparametric statistics have been developed for such purposes. One of these is the Kolmogorov-Sminnov two sample, one tailed test. ${ }^{19}$ In recent years social scientists have contended that Likert scale data, when used to measure opinions or attitudes, is either interval data or approaches it very closely. What this means is that the distance between one and two on the scales used in this study is the same as the distance between each of the other pairs of adjacent numbers. As a result there has been an increasing acceptance of the use of the more sophisticated multivariate statistical techniques to analyze this type of data. Two commonly used multivariate techniques are factor analysis and discriminant analysis. All of the three techniques mentioned are used in this study. The nonparametric analysis allows the researcher to look at each individual statement and to test it as a separate hypothesis. Then the individual results can be grouped together and viewed as a whole to see

${ }^{19}$ Sidney Siegel, Nonparametric Statistics for the Behavioral Sciences (New York: McGraw Hill Book Company, 1956), pp. $127-136$. 
if some generalizations can be made about perceptions. The multivariate technique, discriminant analysis, on the other hand, looks at the group of statements as a whole and tries to determine whether the statements do discriminate between the groups that are being tested. Thus the researcher is looking at the problem from two different vantage points, and if the results should both verify his hypothesis, his case is much more strongly supported.

Kolmogorov-Sminnov. The first test is the KolmogorovSminnov two sample, one tailed test of significance. This "is a test of whether two independent samples have been drawn from the same population (or from populations with the same distribution)." 20 It does this by testing the cumulative distributions of the two samples. Each of the fortynine statements is treated as a separate hypothesis. The null hypothesis is that there is no difference between the perception of the exporter and the non-exporter for the view expressed by that particular statement. The greater the number of times the null hypothesis is rejected, the more the general hypothesis of the study is supported. Originally all exporters were to be compared with all non-exporters, but because of the appearance of the non-committed exporter a change has been made. The original comparison is made as planned, but then a second test is made comparing the com-

${ }^{20}$ Ibid., p. 127 
mitted exporter with the non-committed exporter and the nonexporter.

Factor Analysis. Kerlinger defines factor analysis as "a method for determining the number and nature of the underlying variables among a large number of measures." 21 It was developed in the behavioral field to reduce a large number of variables to a workable number. If, in the forty-nine variables represented by the forty-nine statements, there are several groups that are closely correlated, then factor analysis is the way to isolate these factors. Therefore, the next manipulation is a factor analysis of the forty-nine variables using both exporters and non-exporters.

Discriminant Analysis. This is a multivariate technique which attempts to predict which of two or more groups an indivicual belongs to. 22 In this case, if the technique works, one could give this set of perception statements to another sample of small manufacturers and predict from their answers whether they are committed exporters, non-committed exporters or non-exporters. This then becomes a measure of whether or not the perceptions of these groups are different, for if one can accurately predict group membership on the

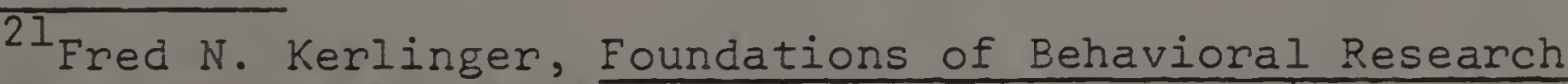
(Hew York: Holt, Rinehart and Winston, Inc., 1964), p. 650 . 22 William F. Massy, "Discriminant Aralysis of Audience Characteristics," in Multivariate Analysis in Marketing: Theory and Application, ed. by David A. Aaker (Belmont, California: Wadsworth Publishing Co., Inc., 1971), p. 117 . 
basis of perceptions of exporting, then there must be a difference in the perception between groups.

\section{Limitations of the Research}

In order to have reliability in the research and to be able to generalize the results to the population at large, it is necessary to have a random sample. In reality this is almost impossible to obtain, and, in this instance, since a convenience sample was used, no attempt at randomness has been made. However, this area of research is still largely unexplored, and this study is a preliminary one. While the results cannot be generalized, they do indicate some interesting possibilities which should be explored with further research.

The use of a nonparametric statistical test eliminates many of the assumptions which must be made when using parametric tests. Siegel ${ }^{23}$ says that the only two assumptions that must be met are that the observations are independent and that the variable under study has underlying continuity. Independence is assured since the decision makers have no idea who has been contacted previously, and so their answers are not influenced by the answers given by the other decition makers. Siege ${ }^{24}$ says that matters of opinion

\footnotetext{
${ }^{23}$ Siegel, op. cit., p. 31.

${ }^{24}$ Siegel, op. cit., p. 25 .
} 
classified as agree and disagree may be thought to fall on a continuum and so would be continuous. For these reasons, the researcher can assume that the assumptions for the Kolmogorov-Sminnov test are met. Another factor is that the nonparametric test has less power efficiency than a parametric test. This deficiency can be overcome by using a larger sample size. The Kolmogorov-Smirnov test has the advantage that it requires only ordinal data, rather than the interval data required by the multivariate statistics. Therefore, if there is a question about the appropriateness of the discriminant analysis with this data, and if the results of the Kolmogorov-Sminrov tests and the discriminant analysis are similar, then this would tend to confirm that the data is interval scaled, and the use of a multivariate technique is appropriate.

As pointed out above, both factor analysis and discriminant analysis require interval data. For years data from a Likert type scale was considered ordinal data. The rationale behind this was that there was no evidence that the distance between any tho adjacent steps on a sixpoint scale, defined by such ambiguous terms as generally disagree, moderately disagree, roderately agree, generally agree is the same for all subjects in the study. However, in recent years this view has been challenged by a number of social science 
researchers. Torgenson ${ }^{25}$ says that subjects are able to judge these characteristics on equal interval scales and any minor differences found are measurement differences such as would be true of any measurement procedure. In this study, therefore, the data from the "Opinions of Exporting" section is assumed to be interval data.

Factor analysis assumes linear relationship between the variables. 26 Discriminant analysis makes a number of assumptions about the data, and it was not possible to verify these assumptions for this study. They are:

1. That the within-group covariation and dispersion are equal across groups.

2. That the profiles are multinormally distributed with known covariation and dispersion.

3. There are equal costs of misclassification and equal probabilities of a sample point's belonging to each set of a priori defined groups. 27

25 Warren S. Torgenson, Theory and Methods of Scaling (New York: John Wiley and sons, Inc., 1958), Pp.61-63. ${ }^{26}$ Green and Tull, op. cit., p. 403 . 27 Green and Tull, op.cit., p. 372 . 


\section{H A P TER III}

THE RESEARCH

Description of the Research Process

Selection of the participants. The research instruments were pretested in July 1975 using a sample of seven small New Hampshire manufacturers. The next step was to select prospects for the interviews and to convince them to participate. Earlier, for reasons discussed in Chapter II, the decision had been made to use a convenience sample rather than the theoretically more correct random sample. The Massachusetts Industrial Directory $1974-75^{1}$ was used as a selection guide since it contained the pertinent information required to select the companies, i.e., company name, address, telephone number, employment, Standard Industrial Classification (SIC) code of the company's principal product, and the name of the chief executive. Although the information was more than two years old, and although a number of errors were found, no other similar statewide industrial reference was available, and it proved invalu$a b l e$ in the selection of prospective firms.

Geographic areas covered. In order to speed up and simplify the interviewing process, the study concentrated

\footnotetext{
${ }^{1}$ Massachusetts Industrial Directory $1974-75$, (Boston, Massachusetts: Department of Commerce and Industry).
} 
on one geographic area at a time. The first interviews were made in Worcester on August 19, 1975. After a few weeks in Worcester, the study moved in succession to the Cambridge, Boston, Everett, and the greater Springfield areas. Then it moved back to the Worcester area again, and the final interview was made in Orange on December 12, 1975.

Enlistment procedures. Initially it appeared that it might be easier to persuade companies to participate in the study if it were possible to obtain the endorsement of some well-known organization or individual. (Later events appear to have proved that this assumption was erroneous.) The United States Department of Commerce, the Associated Industries of Massachusetts, and various members of the Committee on the University as a Commonwelath Resource had indicated some interest in the research and had promised to help in enlisting firms to participate in the study. Mr. Louis $\mathrm{J}$. Camarra, vice president of the Norton Company and the Worcester area representative of the Department of Commerce District Export Council (DEC) was the first person approached. He picked thirteen names from a list of Worcester area firms that met the specifications of the research design and gave permission to use his name on letters sent to this group. ${ }^{2}$ His endorsement appeared to have been helpful as eight interviews resulted from the thirteen letters that were sent. Be-

\footnotetext{
${ }^{2}$ Sample letter is in Appendix $D$.
} 
cause of the success in the Worcester area, when the interviewing moved to the greater Boston area, Dr. D. J. Enright, Director of Research of the International Marketing Institute in Cambridge was contacted, and he agreed to let his name be used on letters sent to firms in the greater Boston area. As a result all letters sent to companies in Boston and Cambridge carried his endorsement. 3 Nevertheless, the response in these two cities was disappointing when compared to Worcester. Since the Boston area contains a large number of research oriented colleges and universities, the heads of many of the companies in greater Boston apparently have received what they consider to be an unreasonable number of requests by faculty and students for permission to conduct some sort of research at these companies. In self defense, many of the executives have had to arbitrarily refuse all such requests.

About half way through the study it appeared that perhaps an outside endorsement of the research was unnecessary, and so it was temporarily abandoned. The results appeared to be comparable with the previous ones, so, except for two isolated cases where individual companies recommended that the interviewer call on a particular company, no more outside recommendations were used. The letter used was essen- 
tially the same as before except that the endorsement was lacking. 4 In retrospect, it appears that time could have been saved, and equal results could have been obtained if the third letter had been used for all prospects from the beginning.

Problems in balancing the sample. National statistics show that less than ten percent of United States manufacturers export any of their product, but this study showed an entirely different pattern. In the first eleven interviews there were only two non-exporters, and after thinty interviews the required twenty-five exporters had been found. Finally, as this pattern continued unchanged, the letter to potential prospects was changed. In order to eliminate exporters, only non-exporters were invited to participate. $^{5}$ Sixty-five letters of this type were sent out, and fourteen interviews were obtained. Twenty-five eliminated themselves because they were exporters, and twenty-six either could not be contacted or refused for reasons other than the fact that they were exporters. At the same time one other change was made in order to find more non-exporters. Another SIC group, number 34 (fabricated metal products, except machinery and transportation equipment), was added. While one could still classify this

\footnotetext{
${ }^{4}$ Sample letter is in Appendix D. ${ }^{5}$ Sample letter is in Appendix D.
} 
as high technology, it had not been used in the Rieth study referred to earlier and so had not been used previously in this study. A total of one-hundred seventy-seven letters were sent. Table $3-1$ gives a breakdown of the response rate by types of letters, i.e. the general letters that made no mention of exporting and the last letter that asked only for non-exporters.

Committed and non-committed exponters. As discussed in Chapter II, the study uncovered a second group of exporters who appeared to act at times like exporters and at times like non-exporters. 6 Seven of these were found, and they were designated as non-comitted exporters, while the balance of the exporters were called comitted exporters. Because of this finding, two sets of statistics have been run. The first compares all exporters with all non-exporters while the second compares the comitted exporters with the non-comitted exporters and the non-exponters. As will be pointed out later, this second comparison often appears

${ }^{6}$ The following is taken from a comment on an interview sheet of a decision maker whose company makes electronic components. One of his lange customers insists that he ship his product to Canede and to Western Europe, and "he says that he is not interested in foreign. travel but that he is really provincial (his words). He also says that exporting was forced on him because of his American customer, and, by implication, he would not do it if he could get out of it. From this he really comes in the ron-export class although he isn't. It would be interesting to run his figures with the non-exporters." 


\section{TABLE $3-1$}

\section{INTERVIEWS GRANTED BY \\ TYPE OF LETTER SENT}

$\begin{array}{lll}\text { Type of Letter } & \begin{array}{l}\text { Number of } \\ \text { Letters Sent Granted }\end{array} & \text { Interviews Response } \\ & & \text { Rate }\end{array}$

\begin{tabular}{lrll}
\hline All Letters & 177 & 59 & $33.3 \%$ \\
Regular Letters* & 112 & 45 & $40.2 \%$ \\
Non-Export Only** & 65 & 14 & $21.5 \%$ \\
\hline
\end{tabular}

* Letter made no mention of exporting.

$*$ Letter asked for non-exporters only. 
better than the first one. For simplicity in data analysis and recording, the following symbols will be used in many of the further discussions of these variables.

$\begin{array}{ll}\text { Committed Exporter } & \mathrm{CE} \\ \text { Non-committed Exporter } & \mathrm{NCE} \\ \text { Non-exporter } & \mathrm{NE} \\ \text { All Exporters } & \mathrm{AE} \\ \text { Non-committed Exporters and } & \text { NCE \& NE } \\ \text { Non-exporters } & \end{array}$

The Companies

Company size. Previous research ${ }^{7}$ has shown that the average exporter tends to be larger than the average non-exporter. This study bears this out. The number of employees is the only variable collected in this study other than the forty-nine statements on the perceptions of exporting where a statistically significant difference between the groups was found. Since the original plan of study called for the companies to be matched as closely as possible by number of employees, no provision was made to test for difference in size. However, when the idea of matched pairs was abandoned because there was no way to identify exporters and non-exporters in advance, it then became possible to test the two groups for variations in size. The average employment for all exporters was about 113 people and for all non-exporters

${ }^{7}$ The Michigan Commerce and Commercial Policy Study and the Opinion Research Corporation Study for the U.S. Department of Commerce both mentioned in Chapter $\mathrm{I}$. 
it was 56 people. The mean for the committed exporters was considerably higher than for the non-committed exporters (121.7 to 70.4$)$. A t-test of the difference in the mean of all exporters and the mean of the non-exporters was significant at the .001 level while a t-test of the difference in the mean of the committed exporters with the mean of the non-committed exporters and the non-exporters was significant at the .003 level. Table $3-2 \mathrm{~A}$ contains an analysis of the companies by the number of employees.

In spite of these results, the smallest company in the study has only twenty employees and is a very active exporter. It exports nearly one-third of its annual sales, and its two top executives have divided their world market between them and spend several months each year cultivating these markets. Thus it appears that although larger size may be an advantage for a firm entering the export market, lack of it need not be a deterrent if the company's management has the interest and if the product has a potential market.

Industry classification. Originally the study was limited to five Standard Industrial Classification (SIC) groups which have been classified in the Rieth report as high technology growth industries. The five groups were 28 - Chemicals and Allied Products, 35 - Machinery except Electrical, 36 - Electrical and Electronic Machinery, Equipment and Supplies, 37 - Transportation Equipment, and 38 - Measuring, 
TABLE $3-2 A$

NUMBER OF EMPLOYEES BY EXPORT CLASSIFICATION

\begin{tabular}{|c|c|c|c|c|c|c|c|}
\hline \multirow{2}{*}{$\begin{array}{l}\text { Number of } \\
\text { Employees }\end{array}$} & \multirow{2}{*}{$\begin{array}{c}\text { All } \\
\text { Companies }\end{array}$} & \multicolumn{6}{|c|}{ Export Classification } \\
\hline & & $C E$ & NCE & $N E$ & $\mathrm{AE}$ & NCE & $\varepsilon \mathrm{NE}$ \\
\hline $20-39$ & 13 & 4 & 0 & 9 & 4 & & 9 \\
\hline $40-59$ & 10 & 3 & 1 & 6 & 4 & & 7 \\
\hline $60-79$ & 14 & 4 & 4 & 6 & 8 & & 0 \\
\hline $80-99$ & 6 & 4 & 0 & 2 & 4 & & 2 \\
\hline $100-149$ & 7 & 4 & 2 & 1 & 6 & & 3 \\
\hline $150-199$ & 3 & 2 & 0 & 1 & 2 & & 1 \\
\hline $200-249$ & 2 & 2 & 0 & 0 & 2 & & 0 \\
\hline $250-299$ & 2 & 2 & 0 & 0 & 2 & & 0 \\
\hline $300-350$ & 2 & 2 & 0 & 0 & 2 & & 0 \\
\hline
\end{tabular}

TABLE $3-2 B$

SUMMARY STATISTICS ON NUMBER OF EMPLOYEES

\begin{tabular}{lllllll} 
Statistic & Companies & \multicolumn{1}{c}{ CE } & NCE & \multicolumn{1}{c}{ NE } & AE & NCE \& NE \\
\hline Range & $20-$ & $20-$ & $50-$ & $22-$ & $20-$ & $22-175=153$ \\
Mean & $350=330$ & $350=330$ & $125=75$ & $175=153$ & $350=330$ & \\
Median & 88.932 & 121.704 & 80.429 & 55.920 & 113.206 & 61.281 \\
Standard & 65.250 & 85.000 & 71.250 & 48.000 & 83.000 & 57.500 \\
Deviation & 72.950 & 92.050 & 26.324 & 33.817 & 84.195 & 33.547 \\
\hline
\end{tabular}


Analyzing, and Controlling Instruments: Photographic, Medical, and Optical Goods; Watches and Clocks. For reasons cited earlier in this chapter, SIC group 34 - Fabricated Metal Products Except Machinery and Transportation Equipment, was added later in the study. Table $3-3$ gives a breakdown of exporters and non-exporters by SIC groups. Ideally, exporters and non-exporters would have been paired by SIC group as well as by size, but this was impossible for reasons cited earlier. Therefore, there is a considerable difference in SIC groups between exporters and non-exporters. Exporters were considerably stronger in groups 28,35 , and 36 than were the non-exporters. 14.7 percent of the exporters were in group 38 while there were no non-exporters in this group. These differences certainly introduced some unexplained variance into the study.

The Export Decision Makers

For purposes of this study, the decision maker is defined in Chapter II as "the person responsible for making the decision to export or not to export." In order to disguise the purpose of the study, the letter asking the company to participate asked for an interview with the person responsible for deciding which markets the firm would enter. The letter was always sent to the chief executive and suggested that in a small firm this would usually be the chief-executive or the marketing manager. The company's opinion of the 


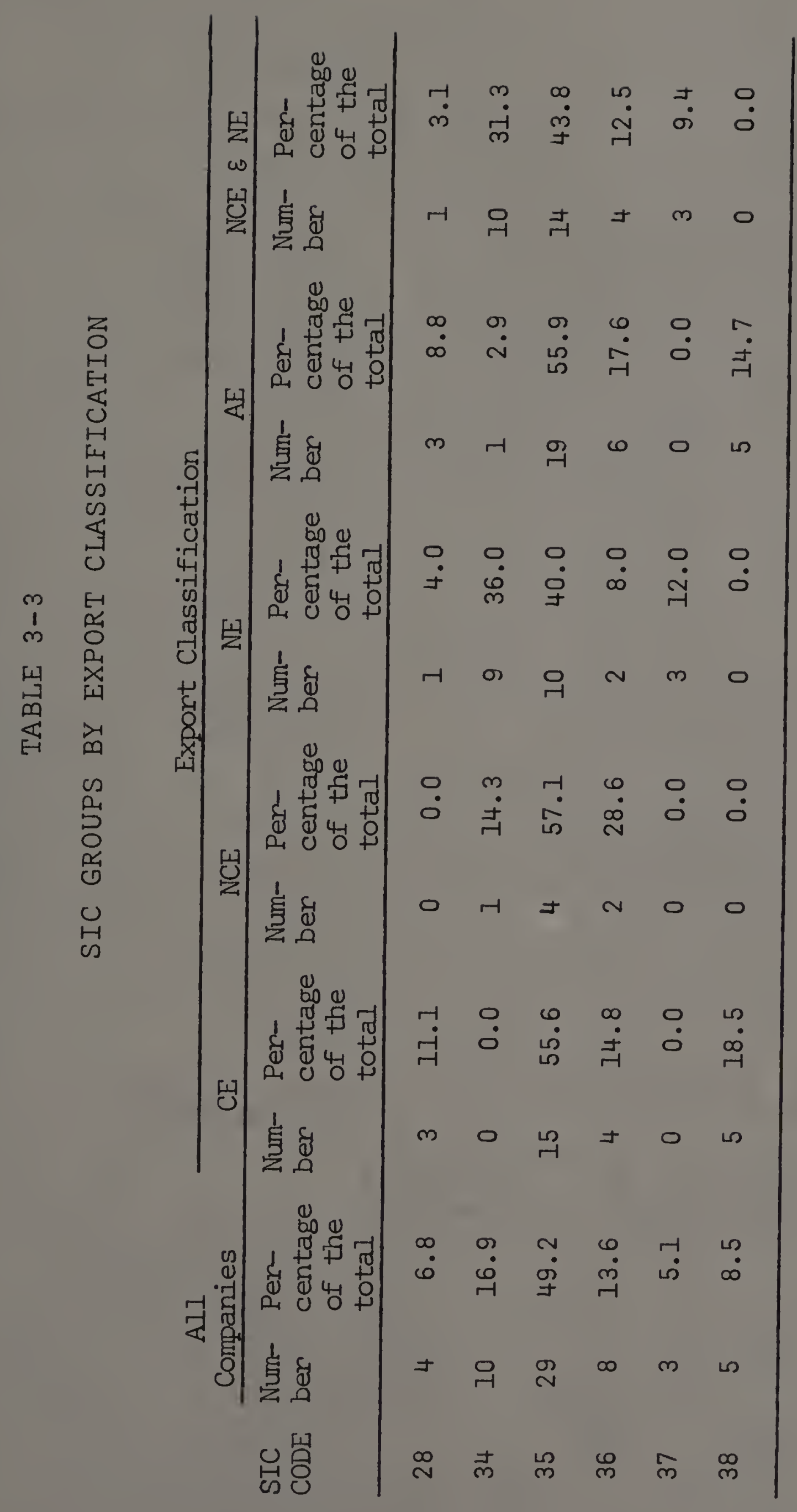


correct decision maker was accepted for use in this study. 8

All of the companies in the survey were corporations. In about half of the cases (thirty out of fifty-nine) the decision maker was a major owner in the business with an interest ranging from 20 percent to 100 percent. The cooperation of the executives that participated in the survey was outstanding. Although many had prefaced their acceptance of an interview with a warning that certain information was privileged, no one refused to answer any questions. Most of the decision makers interviewed were corporate officers, and forty were presidents of their companies. Table $3-4$ gives a breakdown of the decision makers by job classification.

Age of decision makers. Does the age of the decision maker have a bearing on whether a company exports or does not export? Intuitively one might feel that the young are more adventuresome and so might be more prone to exporting. This study found that there was no statistically significant difference in the average ages of the decision makers in the various groups. The two youngest persons interviewed were classified by the interviewer as non-decision makers. Both of them were non-exporters, so that if they had been removed

${ }^{8}$ only four of the persons interviewed did not appear to meet the definition of decision maker, and in at least two of the cases they were closely related to the decision maker (son and brother) so that they appeared to know the rationale for certain decisions even though the decisions were made by others. 
TABLE $3-4$

DECISION MAKERS BY JOB TITLE

\begin{tabular}{|c|c|c|c|c|}
\hline \multirow[b]{2}{*}{ Job Title } & \multirow{2}{*}{$\begin{array}{l}\text { All } \\
\text { Companies }\end{array}$} & \multicolumn{3}{|c|}{$\begin{array}{c}\text { Export } \\
\text { Classification }\end{array}$} \\
\hline & & $C E$ & NCE & $\mathrm{NE}$ \\
\hline President & 39 & 19 & 4 & 16 \\
\hline Division President & 1 & 1 & 0 & 0 \\
\hline Executive Vice President & 2 & 1 & 1 & 0 \\
\hline V.P. Marketing & 1 & 1 & 0 & 0 \\
\hline Vice President & 1 & 1 & 0 & 0 \\
\hline Vice President-Treasurer & 2 & 0 & 0 & 2 \\
\hline Treasurer \& General Manager & 1 & 0 & 0 & 1 \\
\hline Treasurer & 2 & 0 & 0 & 2 \\
\hline Assistant Treasurer & 1 & 0 & 0 & 1 \\
\hline Controller & 1 & 0 & 0 & 1 \\
\hline Marketing Director & 1 & 1 & 0 & 0 \\
\hline Sales Manager & 5 & 2 & 2 & 1 \\
\hline General Manager & 1 & 1 & 0 & 0 \\
\hline Office Manager & 1 & 0 & 0 & 1 \\
\hline Totals & 59 & 27 & 7 & 25 \\
\hline
\end{tabular}


from the calculations, there would have been even less difference in the average ages of the groups. Table $3-5$ lists information about the ages of the decision makers, including a breakdown by export categories.

Education. Simpson ${ }^{9}$ found that one factor which discriminated between exporters and non-exporters was the educational level of the decision maker. This study found no such difference. One explanation could be that Simpson's sample contained companies manufacturing a wide variety of products, whereas the companies in this study all made high technology products. The formal education of the decision makers varied from twelve years to twenty-two years. However, the large concentration was in the sixteen to eighteen year bracket. This means that most of the decision makers had a bachelor's degree, and many had a master's degree as well. Seventeen had engineering degrees, and sixteen had business degrees. Table $3-6$ gives a summary tabulation of years of education by export classification.

Foreign language capabilities. One result of this study was rather surprising. The decision maker was asked whether or not he read or spoke a foreign language and, if so, which one. Intuitively one would not expect a great difference between the two groups but would expect, however,

${ }^{9}$ Claude L. Simpson, Jr., "The Export Decision Process: An Interview Study of the Decision Process in Tennessee Manufacturing Firms" (unpublished PhD dissertation, Georgia State University - School of Business Administration, 1973). 
TABLE $3-5 A$

AGE OF DECISION MAKERS BY EXPORT CLASSIFICATION

\begin{tabular}{|c|c|c|c|c|c|c|}
\hline \multirow{2}{*}{ Age } & \multirow{2}{*}{$\begin{array}{l}\text { All } \\
\text { Decision } \\
\text { Makers }\end{array}$} & \multicolumn{5}{|c|}{ Export Classification } \\
\hline & & $\mathrm{CE}$ & $\mathrm{NCE}$ & $\mathrm{NE}$ & $\mathrm{AE}$ & NCE \& NE \\
\hline $25-34$ & 4 & 0 & 1 & 3 & 1 & 4 \\
\hline $35-44$ & 14 & 9 & 1 & 4 & 10 & 5 \\
\hline $45-54$ & 22 & 10 & 3 & 9 & 13 & 12 \\
\hline $55-64$ & 17 & 6 & 2 & 9 & 8 & 11 \\
\hline 65 and over & 2 & 2 & 0 & 0 & 2 & 0 \\
\hline
\end{tabular}

TABLE $3-5 B$

SUMMARY STATISTICS ON AGE OF DECISION MAKERS

\begin{tabular}{|c|c|c|c|c|c|c|}
\hline \multirow{2}{*}{ Statistic } & \multirow{2}{*}{$\begin{array}{l}\text { All } \\
\text { Decision } \\
\text { Makers }\end{array}$} & \multicolumn{5}{|c|}{ Export Classification } \\
\hline & & $\mathrm{CE}$ & $\mathrm{NCE}$ & $\mathrm{NE}$ & $\mathrm{AE}$ & NCE \& NE \\
\hline Range & $25-67=42$ & $35-67=32$ & $28-60=32$ & $25-64=39$ & $28-67=39$ & $25-64=39$ \\
\hline Mean & 49.237 & 49.926 & 47.714 & 48.920 & 49.471 & 48.656 \\
\hline Median & 51.375 & 51.000 & 53.750 & 51.750 & 51.167 & 52.000 \\
\hline $\begin{array}{l}\text { Standand } \\
\text { Deviation }\end{array}$ & 9.872 & 8.655 & 77.786 & 10.878 & 9.225 & 10.897 \\
\hline
\end{tabular}




\section{TABLE $3-6 A$ \\ EDUCATION OF DECISION MAKERS \\ BY EXPORT CLASSIFICATION}

\begin{tabular}{|c|c|c|c|c|c|c|}
\hline \multirow{2}{*}{$\begin{array}{l}\text { Educational } \\
\text { Level }\end{array}$} & \multirow{2}{*}{$\begin{array}{l}\text { All } \\
\text { Decision } \\
\text { Makers }\end{array}$} & \multicolumn{5}{|c|}{ Export Classification } \\
\hline & & $\mathrm{CE}$ & NCE & $\mathrm{NE}$ & $\mathrm{AE}$ & NCE \& NE \\
\hline \multicolumn{7}{|l|}{ High School } \\
\hline Graduate & 7 & 3 & 0 & 4 & 3 & 4 \\
\hline Some College & 8 & 3 & 2 & 3 & 5 & 5 \\
\hline \multicolumn{7}{|l|}{ Bachelor's } \\
\hline Degree & 18 & 6 & 3 & 9 & 9 & 12 \\
\hline Graduate Work & 26 & 15 & 2 & 9 & 17 & 11 \\
\hline
\end{tabular}

TABLE $3-6 B$

SUMMARY STATISTICS ON EDUCATION

OF DECISION MAKERS

\begin{tabular}{|c|c|c|c|c|c|c|}
\hline \multirow{2}{*}{ Statistic } & \multirow{2}{*}{$\begin{array}{l}\text { All } \\
\text { Decision } \\
\text { Makers }\end{array}$} & \multicolumn{4}{|c|}{ Export Classification } & \multirow[b]{2}{*}{ NCE \& NE } \\
\hline & & $C E$ & NCE & $\mathrm{NE}$ & $\mathrm{AE}$ & \\
\hline Range & $12-22=10$ & $12-22=10$ & $14-18=4$ & $12-19=7$ & $12-22=10$ & $12-19=7$ \\
\hline Mean & 16.051 & 16.370 & 15.857 & 15.760 & 16.265 & 15.781 \\
\hline Median & 16.306 & 16.714 & 16.000 & 16.111 & 16.500 & 16.083 \\
\hline $\begin{array}{l}\text { Standard } \\
\text { Deviation }\end{array}$ & 2.104 & 2.256 & 1.464 & 2.107 & 2.108 & 1.963 \\
\hline
\end{tabular}


that more of the exporters than the non-exporters would have foreign language proficiencies. Actually the reverse was true. Thirty-three out fifty-nine (56 percent) indicated some foreign language proficiency. The breakdown into the three export groups was as follows:

$\begin{array}{lrlr}\text { CE } & 14 \text { out of } 27 & 51.9 \text { percent } \\ \text { NCE } & 3 \text { out of } 7 & 42.9 \text { percent } \\ \text { NE } & 16 \text { out of } 25 & 64.0 \text { percent }\end{array}$

In discussing this with the decision makers, the answer became obvious. First, the foreign language proficiency usually had nothing to do with business. In many cases the decision maker was a second or third generation American, and the foreign language was the one spoken in his home when he was a child. In other cases the foreign language was the one learned at school. Second, many of the decision makers pointed out that for the export of high technology products, English was usually the language used. They said that if a firm had overseas salesmen, these men were expected to be proficient in the language of their customers, but this was not expected of the executives traveling from the United States. As one executive explained, "they like to practice their English, and they speak it much better than I could hope to speak their language." Another executive noted that his company sold to countries all over the world, and while agents were used overseas, one corporate executive handled most of the business with these agents. He said it would be impossible for this one executive to know the number of 
languages necessary to talk with all of the company's major overseas customers.

Foreign travel. Foreign travel was another area that produced some slightly surprising results. Although it is an accepted fact that the airplane has increased the amount of overseas travel tremendously in the past twenty years, the results of this portion of the study were not expected. Only two of the fifty-nine decision makers had not traveled outside of the United States. One was in the non-committed export group while the other was a non-exporter. Much of the travel was for pleasure rather than for business, and so this was probably a measure more of the growth of travel in the United States and of the general affluence of this particular group of individuals than anything else.

\section{Reasons for Exporting or not Exporting}

Simpson 10 found that most of the exporters he studied started exporting because of an unsolicited export order which he defined as a "fortuitous external stimulus." $\mathrm{He}$ also found that a large number of non-exporters had also received foreign export inquiries but had not exported. In this study the exporters were asked why and when they began exporting. The non-exporters were asked if they had ever exported and, if so, why they had stopped. Those who had never exported were asked their reasons for not exporting. 
The results were similar to those found by Simpson. Eighteen out of the thirty-four exporters listed "received an export inquiry" as the reason for starting to export. Three said that they decided to expand the market. The rest, including some of those listed above, amde various comments about their reasons for beginning to export. These are listed in Appendix E. ${ }^{11}$ They show a general optimism about exporting and a belief that larger markets and higher profits are available for those who are willing to expand their horizons.

Tales of two exporters. Two interesting anecdotes might be recalled here. The first concerns a conversation with a committed exporter who was visited about a third of the way through the data collection process. At that time only three non-exporters had been located, and the interviewer was complaining about his poor luck. The decision maker commented that he was not at all surprised because all high technology firms should be exporting.

The second concerns a specialty paint manufacturer. In another interview with a stain manufacturer, the decision

$11_{\text {Two }}$ of the New Hampshire manufacturers interviewed in the pre-test made interesting comments on their reasons for entering the export market. One gave two reasons, diversity and world peace through trade. The other noted that by getting to know more about the mores and thinking in other countries perhaps international tensions can be reduced. Since these ideas run counter to many of the commonly held concepts of the grasping American corporation, they are mentioned here despite the fact that they are not officially part of the study. 
maker described an experience he had had four or five months previously. A visiting customer from Australia had expressed a desire to visit an American paint factory, and so arrangements were made to visit one in a nearby city. The paint manufacturer had never done exporting of any kind, but the Australian was so impressed with the company and its product that arrangements were made for a small sample order. Apparently this proved beneficial to both parties because when this company was visited a few weeks later, the decision maker said that he expected 1975 exports to be about two percent of sales, but in 1976 he felt they would climb to ten to fifteen percent of sales. The paint industry is very seasonal with most of the sales coming in the summer months. Australia, with its seasons reversed from those of the United States, provides a nearly perfect method of evening the peaks and valleys in a seasonal product. It is very interesting to note the speed with which this company acted once it recognized the advantages of exporting.

A view of the non-exporters. What about the non-exporters? Only nine companies or thinty-six percent of those interviewed had never exported while sixteen or sixty-four percent had exported at some time or other. Why did these sixteen companies stop? Generally it was because there were no new orders. The impression which came out of these interviews was that these were unsolicited export orders which the company received and filled but did not encourage. When the 
orders ceased coming, little or no effort was made to determine why they had stopped. The export orders provided extra business, and although the company was glad to receive these orders, when they stopped coming, the company did not feel obliged to actively seek renewals or replacements in the export market.

Why non-exporters do not export. All non-exporters were asked, "Why don't you export?" The answers are tabulated in Appendix F. The general feeling seemed to be that they were too busy with their domestic business, that they were not competitive because of high production and labor costs, or that they could not afford to ship their product overseas because of the high weight and bulk when compared to manufacturing cost. One decision maker had just finished telling the interviewer that he could not ship his product overseas because of its relatively high weight and low value when he started complaining about the competition he was receiving in his domestic business from imports from overseas. The interviewer never did ask him how foreign companies could afford to ship their relatively high weight, low value product across the ocean and still compete with him. A number of companies, especially those in precision machining and stamping noted that they "do not have a product." What they meant was that they do not have a standardized product but instead have machines and skilled technicians capable of turning out precision sub-assemblies and dies for many in- 
dustries. This study found no exporters in these areas, but it did find one non-exporter who had done some limited exporting in the past and one other who is actively investigating export possibilities in Europe. In addition one or two of the companies contacted late in the study, when the letter specifically asked for non-exporters, appear to be in this type of business, and they are exporting.

\section{The Export Decision Makers' Views of the}

\section{Benefits and Problems of Exporting}

When a business expands into a new market, it expects to receive certain benefits, and it also expects to encounter certain problems. If the choice of markets has been a wise one, then one would expect that the benefits would outweigh the problems. Exporting is certainly expanding a market, and so the exporters were asked to describe what they had found to be the principal benefits and the principal problems of exporting. The complete tabulation of their answers is listed in Appendix G. The principal benefits listed were extra sales and profits, expanded markets, and diversification. The consensus seemed to be that, in general, profits tended to be at least as high, if not higher, than domestic profits. The matter of extending the seasons, which was discussed earlier, was also listed as an advantage. The most novel reason was given by a decision maker who said that it gave him a chance to do far more foreign travel than he could 
afford to do in any other way. One commented that he found it interesting while others felt that it helped their corporate image to be recognized as an "international" company and consequently benefitted their domestic business as well.

In the area of problems, most of the decision makers listed numerous problems and then ended by saying that although these problems were not serious deterrents to exporting, they were problems that they usually did not encounter in their domestic business. The most commonly mentioned problems were paperwork, communications, time and distance involved, language, foreign exchange, and credit. The committed and the non-committed exporters both talked about the same kinds of benefits, but in the problem areas, the noncommitted exporters appeared more concerned with foreigh competition, foreign government subsidies, and finding suitable foreign agents and distributors than were the committed exporters.

\section{Summary of the Research Process}

This chapter describes the data gathering process and some of the preliminary findings. It begins by describing the methods used to gather data for the research, the rationale for various decisions that were made, and the problems that appeared due to unforeseen circumstances. It continues by giving some general information about the companies in the study and finally draws a picture of the export decision 
makers, discusses the reasons they gave for exporting or not exporting, and looks at what the exporters felt were the principal benefits and the principal problems of exporting. The next chapter will review the nonparametric analysis of the forty-nine statements, "Opinions of Exporting." 
C H A P T E R IV

NONPARAMETRIC ANALYSIS OF THE RESULTS

The Decision Maker's Perceptions of Exporting

The principal purpose of this research was to study the decision makers of small Massachusetts firms in order to determine whether or not there was a difference in the perceptions of exporters and non-exporters toward such aspects of exporting as risk, profit potential, costs, problems, and personal rewards. Since man has an inherent fear of the unknown, some of the differences found in any study of this sort are probably explained by this fear. One decision maker said that the first few export orders in his company created a real crisis as executives and clerks struggled to decipher government regulations and to complete all of the necessary paperwork. Today he said that although the paperwork still needs to be completed, the clerks in his office know exactly what needs to be done, and it is a routine operation requiring none of his time. One possible way to eliminate this variable of fear of the unknown would be to follow the procedure used by simpson. I He limited the exporters in his study to firms which had been exporting for

${ }^{1}$ Claude L. Simpson, Jr., The Export Decision Process: An Interview Study of the Decision Process in Tennessee Manufacturing Firms, (unpublished PhD dissertation, Georgia State University - School of Business Administration, 1973). 
only a few years. He asked these exporters for their opinions of the various aspects of exporting that he was testing, both at the time of the interview and before they began exporting. He found very little difference in the answers. This could mean that there was little change in the decision maker's perceptions because of experience, or it could mean that although the decision maker's perceptions changed because of his experience in exporting, he actually forgot his earlier feelings. If there is little actual change in the decision maker's perception over time, there is no reason to ask the same question twice. If, on the other hand, there is a change, but the decision maker does not recognize it, then there is still no reason to ask the question twice. Therefore Simpson's method was not used.

The measuring instrument. Forty-nine statements were developed to measure the decision maker's perceptions of exporting. These came from many sources. Some were taken from answers given to researchers in various published studies. Some came from the comments of international marketing experts in both books and journals. Some came from discussions which the researcher had with students and faculty at the University of Massachusetts, and some came from the researcher's own personal experiences and his discussions with friends in the business community. The statements were pretested, as described in Chapter II, and a number of the 
original statements were either changed or omitted. ${ }^{2}$

Summary of the test results. In the comparison of the exporters against the non-exporters, eighteen of the statements were significant at the .10 level or better. ${ }^{3}$ In addition four statements were very close to the .10 level of significance. As pointed out in Appendix $c$, this is a large sample test for sample sizes of forty or more, and, while it may be used for smaller sized samples, it gives a conservative test. Therefore, if it had been possible to use the small sample test, it appears quite possible that these four statements might have been significant also. In the comparisons of the committed exporters against the non-committed exporters and the non-exporters, the results were even stronger. Twenty-three of the statements were significant at the .10 level or better, and one statement was close to the .10 level. Sixteen of the statements were significant in both sets of tests.

The one-tailed test used in this analysis measures the direction of the differences between the two samples, i.e., are the values from one population larger than the values from the other population being measured? Interestingly enough, the results, with one possible exception, were in

\footnotetext{
${ }^{2}$ A copy of the "Opinions of Exporting" is in Appendix A. ${ }^{3}$ The . 10 level of significance is often used in nonparametric analysis.
} 
the direction which would be normally predicted. The one exception was statement nine - The Commonwealth of Massachusetts does nothing to help increase exports. The Commonwealth does have an international section in its Department of Commerce and Development, so one would normally expect that exporters would disagree with this statement, and nonexporters would agree. However, the reverse was true, and from some of the remarks made to the interviewer, it appears that there is little actual help for the exporters. The exporters, of course, knew this from experience while the nonexporters had only been reading the department's press releases.

\section{Analysis of the Kolmogorov-Sminnov Results}

The results of the Kolmogorov-Smirnov tests will be analyzed in this section. One fact should be emphasized, however. This statistic is a measure of rank order, so that both groups could be opposed to a statement and still have a statistically significant difference in the results. For instance, if most of the exporters strongly disagreed with a statement while most of the non-exporters generally disagreed or moderately disagreed, the statistic would measure the degree of disagreement and might indicate a statistically significant difference. ${ }^{4}$

\footnotetext{
${ }^{4}$ The Kolmogorov-Smirnov analysis of the twenty-six var-
} iables discussed in this section is in the Appendix $H$. 
Although it was mentioned earlier, it is well to point out once again the limitations of the convenience sample used in this study. AII statistical tests used in this study are predicated on a random sample. Therefore the results of the tests cannot be generalized to a wider population.

Ideally the Kolmogorov-Smirnov test would have shown a statistical significance between exporters and non-exporters on all of the forty-nine statements on the "Opinions of Exporting." This did not happen, although a substantial number of the statements did appear to discriminate between the two groups. As was mentioned earlier, two groups of tests were made. The first compared all exporters with all nonexporters while the second compared the committed exporters with the non-committed exporters and the non-exporters. Table 4-1 contains a summary of the results of the KolmogorovSmirnov analysis of the "Opinions of Exporting." Using the common .05 or better level of significance, fifteen out of forty-nine statements were significant in a comparison of exporters with non-exporters, while in a comparison of committed exporters with non-commited exporters and non-exporters, the figure is eighteen. If the .10 level is used then three more statements can be added to the first group and five to the second group.

The first statement read, Exporting is very risky. I'd rather go to the racetrack. Then at least I could have a good time while I lost my money. This statement was intended 
TABLE $4-1$

\section{RESULTS OF THE KOLMOGOROV-SMIRNOV ANALYSIS}

Significance Level Significance Level CE vs. Var. CE vs. Var. Var. \# AE vs. NE NCE \& NE$$
1
$$

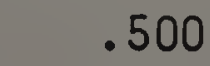

.750

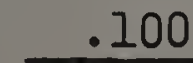

.025

.025

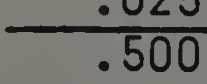

.500

.500

.250

.100

.500

$\because .250$

.750

.010

.010

.900

.100

.050 \# AE vs. NE NCE \& NE

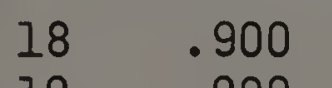

19

20

21

23

23

25

.900

. .100

$\because .250$

.001

.250

.100

$\frac{.050}{.250}$

26

27

28

29

.500

.950

$* .250$

.500

30

.500

$31 \quad .250$

32

33

.750

.500

.025

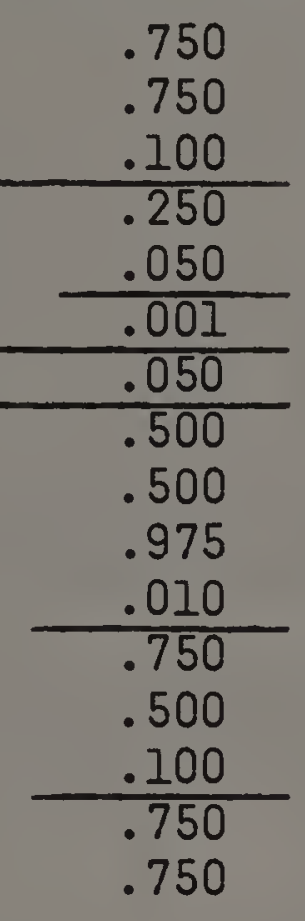

34
35
36
37
38
39
40
41
42
43
44
45
46
47
48
49
\# AE vS. NE NCE \& NE

.250

.500

.750

.500

.025

*. 250

.0250
.007

.001

.005

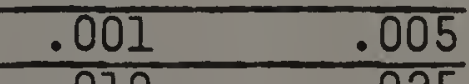

$\frac{.010}{.750}$ .025

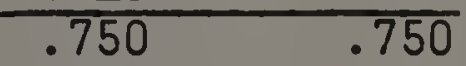

.500

.500

.025

.010

.500

.050 .001

.005 .050

.500

.750 .005

.025

.750 .010

* Nearly significant at .100 level

Summary of Significant Kolmogorov-Snirnov Results

Significance Level

AE vS. NE NCE \& NE

\begin{tabular}{|c|c|c|}
\hline & .001 & 3 \\
\hline & .005 & 1 \\
\hline & .010 & 4 \\
\hline & .025 & 4 \\
\hline & .050 & 3 \\
\hline & .100 & 3 \\
\hline Close to & .100 & 4 \\
\hline
\end{tabular}


as a measure of the decision maker's perception of risk.

Numerous studies, including the one by Simpson, had indicated that risk was one factor that hindered exports. This question was not significant for $A E$ versus $N E$ but was significant at the . 10 level for $C E$ versus NCE \& NE. The reason for this was that the non-committed exporters acted more like the nonexporters than they did like the committed exporters. It is interesting to speculate on why the results turned out as they did. One can understand the non-exporter feeling that the risks of exporting were too great so that he did not want to get involved in such a risky venture. However, the noncomnitted exporter is involved in exporting, albeit unwillingly. He should know something about the risk, and unless he experienced some great loss due to exporting, which was never mentioned, why should he feel that exporting was so risky? One explanation, at least for some of these companies, is that their export business was confined to one or two large customers. Usually these were foreign subsidiaries of an American customer, so they felt as though they were dealing with an American company rather than a foreign one.

Statement 3, Exporting is very difficult because the most desirable markets have high tariff barriers, was significant at the .025 level for $A E$ versus NE but was not significant for $C E$ versus NCE \& NE. The explanation here appears simple. Those engaged in exporting, whether committed or not, know what the tariff situation is. For the non-exporter, 
it is a fear of the unknown.

Statement 4, Products utilizing new or advanced technology are easier to export than are products using older and more simple technology, was significant in both groups. In the comparison of $A E$ versus $N E$, it was significant at the .025 level, while the other group, CE versus NCE \& NE, was significant at the .005 level. Using the theory of comparative advantage, the textbook answer to this question would be to strongly agree. In all of the groups more than fifty percent did agree with the statement. However, the non-committed exporters and the non-exporters agreed more strongly than did the committed exporters. This would tend to support the theories of this study. While the non-committed exporters and the non-exporters tend to accept "general knowledge" as so, the committed exporter is not necessarily convinced, and so perhaps by using an extra marketing effort, he is able to easily compete in the export market with a product which does not utilize the newest technology. Statement 8 , The paper work involved in exporting is too complicated and expensive for our company, was not significant in $A E$ versus $N E$ but was significant in $C E$ versus NCE \& NE at the .10 level. This is in accordance with the hypothesis of this study. The committed exporters have routinized the paperwork so that it is no problem while the non-committed exporters and the non-exporters both fear it. 
Statezent 9 , The Commonwealth of Massachusetts does nithing to heip increase exports, was found significant by both grcups, at the .I0 level for $A E$ versus $N E$ and at the .001 level for CE versus NCE \& NE. The interesting factor, as cescribed earlier, is that the non-comitted exporters and the nor-exporters tended to disagree with this statement uore than the comitted exporters did.

Statement II, The complications of ocean shipping are so great that exporting is not a worthwhile venture for a s=ail company: was not significant for AE versus $N E$ although it was very close to the .10 level of significance, but for CE versus MCE \& ME, it was sigrificant at the . 10 level. Once again this supponts the hypothesis of this study that the ron-exponters perceive the problems of exporting to be Ereater than do the exporters. In this case the non-committed Exportens have once again behaved more like non-exporters than like exporters.

\section{Statement I3, I con't speak any language but English} and therefore would be reluctant to try and get into the expont business, was significart in both groups, AE versus NE at the.0I0 IEvel ard CE versus IHCE \& IHE at the .025 Ievel. Both grcugs disagreed with the staterent, but the exporters texded to disagree with it rore. Several of the committed exporters etressed the fact that in most countries the knowIEdgৎ of English among their custorers was high and that zany of these people preferred to do business in English even 
when the American spoke the customer's language rather fluently.

Statement 14, The political instability in the world makes it very risky to engage in export business, was significant in both groups, $A E$ versus $N E$ at the .010 level and CE versus NCE \& NE at the .005 level. This of course supports the hypothesis of this study that the non-exporters perceive the risks of exporting to be greater than do the exporters, and this was another example where the non-committed exporter behaved more like a non-exporter.

Statement 16, The multinationals have ruined the export business by opening plants in most of my best potential markets, was significant in both groups, $A E$ versus $N E$ at the .10 level and $C E$ versus NCE \& NE at the .005 level. The non-committed exporter again behaved more like a non-exporter and expressed a protectionist fear of "unfair" overseas competition.

Statement 17, Exporting is not as rewarding as dealing with my domestic customers, was significant in both groups, at the .050 level for $\mathrm{AE}$ versus $\mathrm{NE}$ and at the .025 level for $\mathrm{CE}$ versus $\mathrm{NCE} \& \mathrm{NE}$. This statement was an attempt to arrive at some measure of the personal rewards and achievements in exporting, and once again the non-committed exporter was grouped more closely with the non-exporter than with the committed exporter. 
Statement 20 , I would like to export, but I don't know where to go for help, was significant in both groups at the .10 level. There are, of course, many places where a company can go for help if it is interested in entering the export market, but, once again, the non-exporter perceived the problems to be much greater than did the exporter.

Statement 22, Export business is a nuisance and should therefore provide an extra mangin of profit when compared to domestic business, was significant at the .05 level for the CE versus the NCE \& NE group. Although the results were not significant for the $A E$ versus the $N E$ group, they were close to the .10 level. Once again the non-committed exporter was more closely aligned with the non-exporter than with the committed exporter. In the interviews many of the committed exporters said that the profit on exports tended to be somewhat higher than their domestic profits but that this was because of market demand conditions. Most of them also expressed the willingness to operate on lower than normal profit margins in their export markets when the market conditions seemed to require it.

Statement 23 , We must start exporting now if our company is going to continue to grow, was significant at the .001 level for both groups. As might have been predicted, the non-exporters disagreed and were generally content to service the domestic market. 
Statement 24, Exporting is a very viable method of increasing sales for a small company, was significant at the .05 level for both groups. Once again the non-exporter shows no interest in the export market, presumably because he perceives the problems as much too great for any possible benefits he might receive.

Statement 25 , Exporting is difficult because it is hard to check credit references in foreign countries, was not significant in either group, but it was almost significant at the .10 level for AE versus NE. Here the non-committed exporter behaved more like the committed exporter, probably because he had had experience which the non-exporter had not. Statement 28 , The government is only interested in big business. Its programs to aid exports, such as DISC, are geared to the large corporations and are too complicated and expensive for a small company, was significant at the .01 level in the $C E$ versus the NCE \& NE group. It was not significant for the $A E$ versus the $N E$ group, but it was close to the .10 level of significance. Once more this is an example of the non-committed exporter behaving more like the nonexporter.

Statement 31 , The advent of the European Common Market has made exporting to Europe a very difficult process, was significant at the .10 level for the CE versus the NCE \& NE group. This is still another case where the non-committed exporter behaved more like the non-exporter than he did like 
the committed exporter, and both of them apparently perceived the export problems as greater than did the committed exporter. Statement 36 , I feel that the contacts I could make in exporting would give me a better understanding of the problems of the world, was significant at the .025 level for the $A E$ versus the $N E$ group. It was not significant for the $C E$ versus the NCE \& NE group, but it was nearly significant at the .10 level. Interestingly, the non-exporters tended to agree with this statement more than the exporters, who were more or less unified this time. Apparently the exporters have found that most of their foreign travel is spent in talking business, and so they have little time to worry about the world's problems.

Statement 38 , We have all the domestic business we can handle, and therefore, I am not interested in exporting, was significant in both groups, at the .001 level in the AE versus $N E$ group and at the .005 level in the $C E$ versus the NCE \& NE group. In this case the exporters tended to behave as a unified group whereas the non-exporters showed their fear of the problems of exporting and their general disinterest in exporting.

Statement 39 , There is a large potential market for our product in foreign countries, was significant in both groups, at the .001 level in the $A E$ versus $N E$ group and at the .005 level in the CE versus NCE \& NE group. The exporters appeared as a more or less unified group once more, while the 
non-exporters see no great export market available to them. Statement 40 , Exporting is only for the larger firms, was significant in both groups, at the .010 level in the AE versus $N E$ and at the .025 level in the $C E$ versus $N C E \& N E$ group. The exporters appeared again as a unified group, and the non-exporters accepted the standardized excuses for not exporting.

Statement 42 , Exporting offers me a management specialty that I feel could help solidify my position in the company, was significant at the .025 level in the $C E$ versus NCE \& NE group but was not significant for the AE versus NE group. The non-committed exporters answered more like the non-exporters, and both groups generally disagreed with the statement which was intended as a measure of personal advancement. It apparently failed as a good measure because so many of the decision makers had a substantial financial interest in their company that their position was secure whether the firm exported or did not export. If the study should ever be expanded to medium sized firms with a much larger percentage of professional managers, then this would probably be a very good measure.

\section{Statement 44 , Exporting could be a profitable outlet} for our product, was significant in both groups, at the .010 level in the $A E$ versus $N E$ group and at the .00I level in the CE versus NCE \& NE group. The non-committed exporters once again appeared to be more closely aligned with the non-ex- 
porters than with the committed exponters as they perceived greater problems in exporting than did the committed exporters.

Statemert 45, If a small firm tries to go into exporting, it will find that its executive talent will be spread too thin, and the company's overall performance will suffer, was significant in both groups at the .050 level. In this case ail of the exporters tended to agree with each other and did rot see this as a problem, while the nor-exporters säu it as à definite problem.

Statement 46 , We plan to increase the percentage of our product exported every year in order to attain our desired growth rate, was significant in both groups at the .050 level. The exporters as a group tended to agree with the statement wore then the non-exporters did. The non-exporters odviously felt that their desired grobth could be obtained by other meane.

Statemert 49 , Since exporting means doing business under many different lans, this increases the complezity of management's problens to the point where it is inadvisable for a small company to consider selling outside the domestic market, was significant in both groups, at the .025 level in the f.E versus l'E group and at the .010 level in the CE versus ICE E IIE group. In this case also, the non-comitted $E \%-$ porten behaved more like the non-exporter, seeing as major problens matters which the comitted exporter treated as 
routine.

Twenty-six statements have been discussed here, and of these, twenty-five were significant at the .100 level or better. The twenty-sixth statement was almost significant at the .100 level, and if there had been an appropriate small sample test that could have been used, it appears that it might have been significant as well. In fourteen of these twenty-six cases the non-committed exporter appeared to behave closer to the non-exporter than to the committed exporter. In the other twelve cases the non-committed exporter behaved more like the committed exporter.

An analysis of the statements with significant results is probably easier than one in which the results were not significant. This is especially true when the results had a significance level of $.900, .950$, and .975 as a few of them did. In these cases the results were exactly the opposite of what had been predicted in advance. In general what happened in the non-significant cases was that the two groups behaved more or less alike, and the closer their behavior was to each other, the higher the probability recorded in Table 4-1. Statement Two is a good case in point. The statement reads, Essentially exporting is not different from selling in the domestic market. The Kolmogorov-Smirnov statistic is based on the largest cumulative difference between the two groups, and in this case the difference was not very large. In other words, any difference could be 
attributed to chance. Why did the results come out as they did? Of course exporting is different from domestic business. However, in formulating this statement, the researcher assumed that the exporters would view the problems of exporting as essentially the same as domestic problems with any difference viewed as merely one of degree. On the other hand he felt that the non-exporters would consider the two sets of problems as entirely different. These anticipated differences between the exporters and the non-exporters did not appear, but instead both groups scattered their responses over all six categories.

Statement 6, A small firm is at a great disadvantage in exporting because of limited capital, was a similar situation to the one just mentioned. The researcher made an assumption that was not borne out by the study. At least one non-exporter commented that although he did not plan to do any exporting, if he wanted to, he knew where he could get the necessary money.

The other non-significant statements, which have not been mentioned previously, are listed below without comments.

5. I look on exporting as a real challenge to my managerial capabilities.

7. If we export, I would expect that overseas agents would be readily available to handle our products.

10. Knowledge of the language of a country is important in exporting to that country.

12. It is necessary to change our product specifications for various export markets. 
15. We are at a disadvantage when compared to European exporters because they receive tax rebates on their exports.

18. Exporting is a good way to compensate for excess production capacity.

19. President Ford talks about wanting to increase exports, but the government does nothing to help me in this regard.

21. Foreign travel is advantageous in getting into the export business.

26. A domestic international sales corporation, (DISC), is a big help in increasing the profitability of our export business.

27. Exporting gives me a chance to travel and meet people I could never meet in any other way.

29. Participation in a trade fair is a good way to start or to expand an export market.

30. The company with a manager who has had formal training in international business can do a better job in exporting.

32. Exporting offers significant opportunities for increased profits.

33. If we export, we will have to wait a Iong time for our money.

34. We are at a disadvantage when compared to European exporters because they have government sponsored credit insurance.

35. Exporting is very difficult because many of our products are more expensive than foreign products.

37. Exporting means special problems because we must add people with special expertise.

41. The U.S. Department of Commerce has a number of good programs to help small business get into exporting.

43. Foreign exchange problems make exporting difficult. 
47. The extra volume which comes through exporting allows a company to implement many production efficiencies.

48. College trained marketing executives are necessary if a company is considering entering the export market.

Essentially the answers of the exporters follow the expected pattern. The problem with the questions is that the non-exporters did not differ from the exporters drastically enough to arrive at a significant test. Exactly why is difficult to determine. The important fact is that a number of the forty-nine statements did discriminate, some at very significant levels, and so the general hypothesis of this study that there is a difference in the perception of exporters and non-exporters towards the profits, costs, problems, and personal satisfaction and advancement of exporting is strongIy supported.

Summary of the Nonparametric Analysis

This chapter describes the results of the KolmogorovSmirnov nonparametric analysis. In the comparison of all exporters with all non-exporters, eighteen of the forty-nine statements were significant at the .100 level or better, while in the comparison of the committed exporters with the non-committed exporters and the non-exporters twenty-three statements were significant at the .100 level or better. All of the significant statements are analyzed and discussed, 
including a discussion of the reasons for the different outcomes in the two sets of tests. All of the non-significant statements are listed. The following chapter will discuss the multivariate analysis of the same data. 


\section{H A P T E R V \\ THE MULTIVARIATE ANALYSIS}

\section{Factor Analysis}

In any study of this kind with a large number of variables that are likely to be intercorrelated, the researcher must find adequate methods to discover what relationships, if any, exist between these variables. A multivariate technique called factor analysis is often used to reduce the large number of original variables to a relatively few factors which will explain most of the variance. When he originially drew up the forty-nine statements, the researcher tried to include measurements in five areas: risk, profit potential, costs, problems, and personal rewards. Therefore, it seemed logical to assume that a factor analysis might actually produce factors representing some or all of these general variables.

Therefore, a factor analysis was performed on the data using the standard SPSS factor analysis subprogram FACTOR with a VARIMAX rotation. The initial results were unexpected. The computer warned that "the matrix to be decomposed is nearly singular." This meant that the determinant was nearly zero, and as a result, the inverse of the correlation matrix had some very high numbers in it, and there was multicollinearity present. However, an examination of the correlation matrix failed to show any clear 
evidence of the source of the multicollinearity. The computer warned that one variable was dependent on previous ones, but removing the variable did not materially improve the situation, and the determinant remained very close to zero. This leads to the conclusion that this was a complex situation with a Iinear dependence between groups of variables rather than between single variables.

One of the problems in factor analysis is to decide how many factors to include in the final analysis. Unlike many other statistical techniques, factor analysis depends a great deal on the researcher's knowledge of the variables. As a result, general rules of thumb, rather than hard and fast rules, are often used to guide the researcher. One of these rules of thumb is to include all factors with an eigenvalue of one or greater in the analysis. This rule was used, and fifteen factors were isolated. Normally a variable is considered to load heavily on a factor if it has a .45 or higher loading. In this study the figure was reduced to .40 , but, in spite of that, only twenty variables loaded on the fifteen factors. One factor had three heavily loaded variables in it, three had two, and eleven had only one. The initial conclusion was that the variables were independent and that there was little or no direct intercorrelation between them.

Sometimes it is possible to force a better solution by arbitrarily reducing the number of factors and increasing 
the number of iterations needed to improve the estimates of communality. In the SPSS factor analysis program that was used, the main diagonals of the correlation matrix are replaced by communalities. A "communality is defined as the proportion of a variable sharing something in common with other variables in the set." ${ }^{1}$ Repeated iterations often improve the estimates of communality, but, because the determinant was close to zero, the first iteration estimated the communalities at the upper limit of one. Therefore, increasing the permissible iterations would not improve the results. With ten factors, only nine variables loaded heavily at .40 or better. One factor had no heavily loaded variables while the other nine had one each. No variable loaded heavily on more than one factor.

This meant that factor analysis did not aid the analysis in this study because, instead of being intercorrelated, the variables were independent. ${ }^{2}$ The results did not alter The results did not alter the main hypothesis of the study.

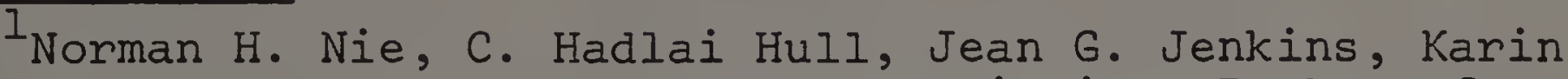
Steinbrenner, Dale H. Bent, SPSS: Statistical Package for the Social Sciences, Second Edition (New York: McGraw Hill Book Company, 1975), p. 480.

2 The researcher was talking about this problem with a professor who teaches multivariate statistics in the Business School at the University of Massachusetts. He examined the computer printout very carefully and then asked for a copy, saying that it was a classic case where factor analysis does not work, and he would like to use it in his courses. 
The factor analysis was not intended to measure perception but merely to try to fit the causes for the difference in perception into some easily defined niches. This it was unable to do. The differences in perception did exist, but the measures, as far as could be determined, were independent. This means that there might also be many more independent variables that have not been isolated that might also measure these perceptions. The next section of this chapter will look at how well these forty-nine statements discriminated between the exporters and the non-exporters.

\section{Discriminant Analysis}

Discriminant analysis is a multivariate statistical technique which attempts to distinguish between two or more groups of cases by developing a number of discriminating variables that measure the characteristics by which the groups are supposed to differ. The discriminating variables were the forty-nine statements about the opinions of exporting. If these statements did, in fact, discriminate between the groups, the main hypothesis of this study, that exporters and non-exporters differ in their perceptions of the risks, profit potential, costs, problems, and personal rewards of exporting, would be strongly supported.

Advantages of the discriminant analysis. There were two readily discernable advantages of discriminant analysis over the Kolmogorov-Smirnov analysis described in the previ- 
ous chapter. The first advantage was that the use of discriminant analysis made possible a comparison of more than two groups. This was something that could not be done in the nonparametric analysis, and so it was possible to run three sets of discriminant tests. Therefore, in addition to the comparison of all exporters with the non-exporters and the comparison of the committed exporters with the noncommitted exporters and the non-exporters, a third comparison of the three groups (committed exporters, non-committed exporters and non-exporters) was made. The second advantage was concerned with the characteristics of the two tests. As explained in the second chapter, the main hypothesis was a general one about the difference in the perceptions of exporters and non-exponters towards various facets of exporting. The nonparametric analysis required that each statement be tested individually, and the results examined to see if some generalized statements could be made from them. Discriminant analysis, on the other hand, looked at the whole and actually tested whether or not the group of variables used was able to correctly classify the cases into their proper group. In this way the variables that were not statistically significant by themselves might, in fact, help to provide a better overall classification.

Computer routine. The standard SPSS subprogram DISCRIMINANT, with the Wilks' lambda criterion for determining the number of discriminant functions, was used. One of the 
problems encountered in running the discriminant analysis was the relatively small number of cases. Only fifty-nine decision makers were interviewed, and, although they were asked to rate every statement, eleven of them left one or more of the statements blank. This particular program automatically discarded all such cases before making the analysis, so that the complete analysis of all the variables used only forty-eight cases: twenty-two for the committed exporters, seven for the non-committed exporters, and nineteen for the non-exporters. Thus an already small number of cases was reduced to an even smaller number. In retrospect it appears that the only adequate solution would have been a substantially larger sample size, but time and financial constraints made this impossible.

Three programs were run initially. In the first, the groups were $C E, N C E, N E$. In the second, they were $A E, N E$, while in the third they were CE, NCE \& NE. With forty-nine variables and only forty-eight cases going into the program, one-hundred percent correct classification was assured, but this run was necessary to provide information for further runs. In order to obtain meaningful results with the relatively small number of cases, the number of variables had to be reduced. The problem was what criteria were to be used. A two step approach appeared to be the best one. First, some initial runs would be made with a relatively large number of strong variables to see the percentage of 
correct classifications, the number of variables would be reduced until a point was reached where the results were no longer statistically significant. The second step would be to start at the other end of the scale with a few variables that the initial stepwise discriminant analysis had shown to be very weak and to run them to see the percentage of correct classifications and the statistical significance of the results. This would be repeated with small groups of increasingly stronger variables until a group of statistically significant variables was found. It could then be assumed that all of the variables above this point in strength should also give good results.

Initial subgroup of variables. The variables that had been significant in the Kolmogorov=Smirnov analysis, as described in Chapter IV, were the first subgroup of variables chosen. If these variables had good predictive power in a discriminant analysis, it would reinforce the findings of the nonparametric analysis. Two sets of runs were made to test this. The first set consisted of the KolmogorovSmirnov variables that were significant at the .10 level or better. All of the results were significant at the .000 level, and the percentage of correct classifications was very high. Summary results of the discriminant analyses of all of the variables and of the strong variables are shown in Table 5-I while the results for the weak variables are shown in Table 5-2. For the CE, NCE, NE run, the twenty- 


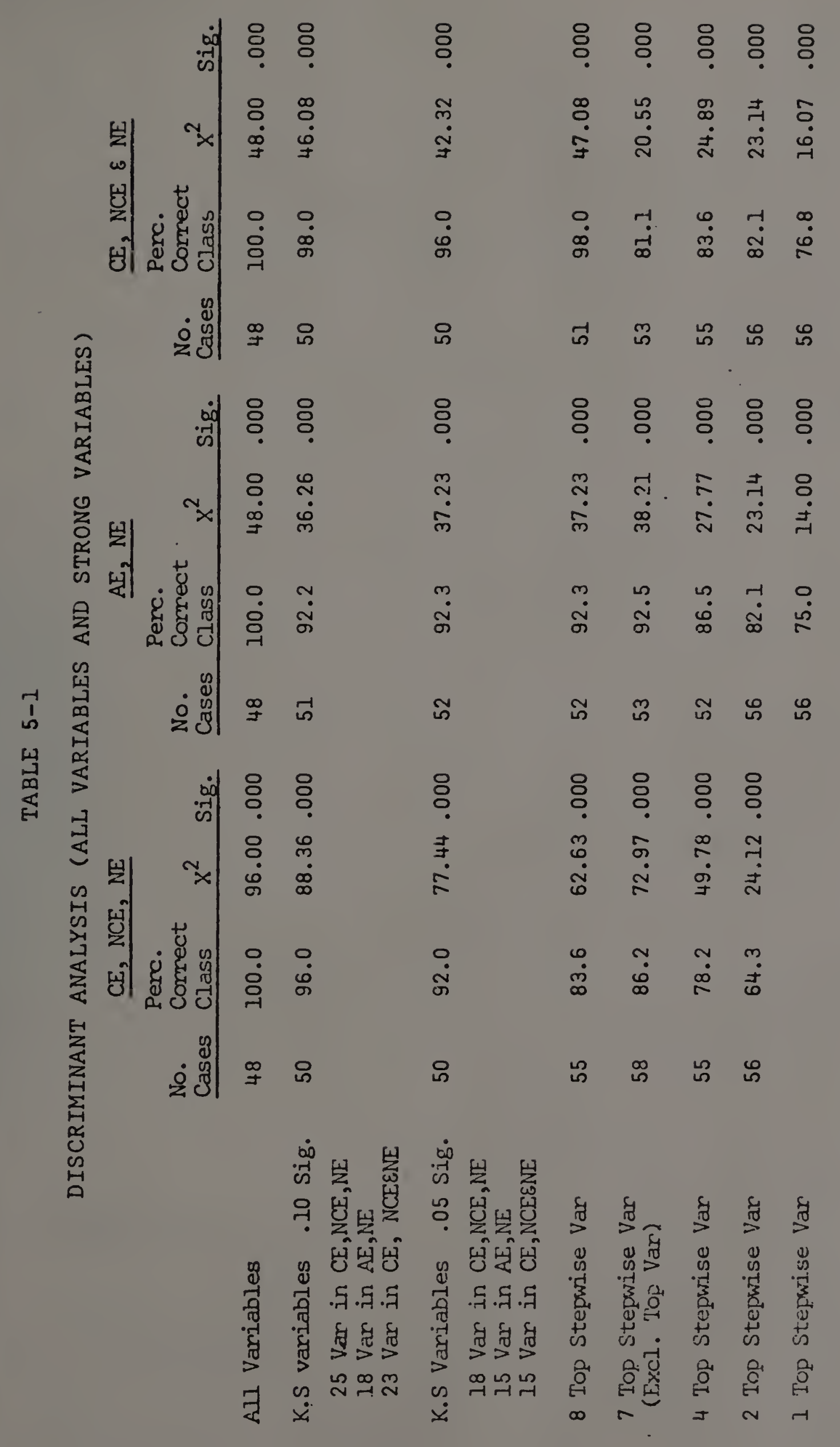




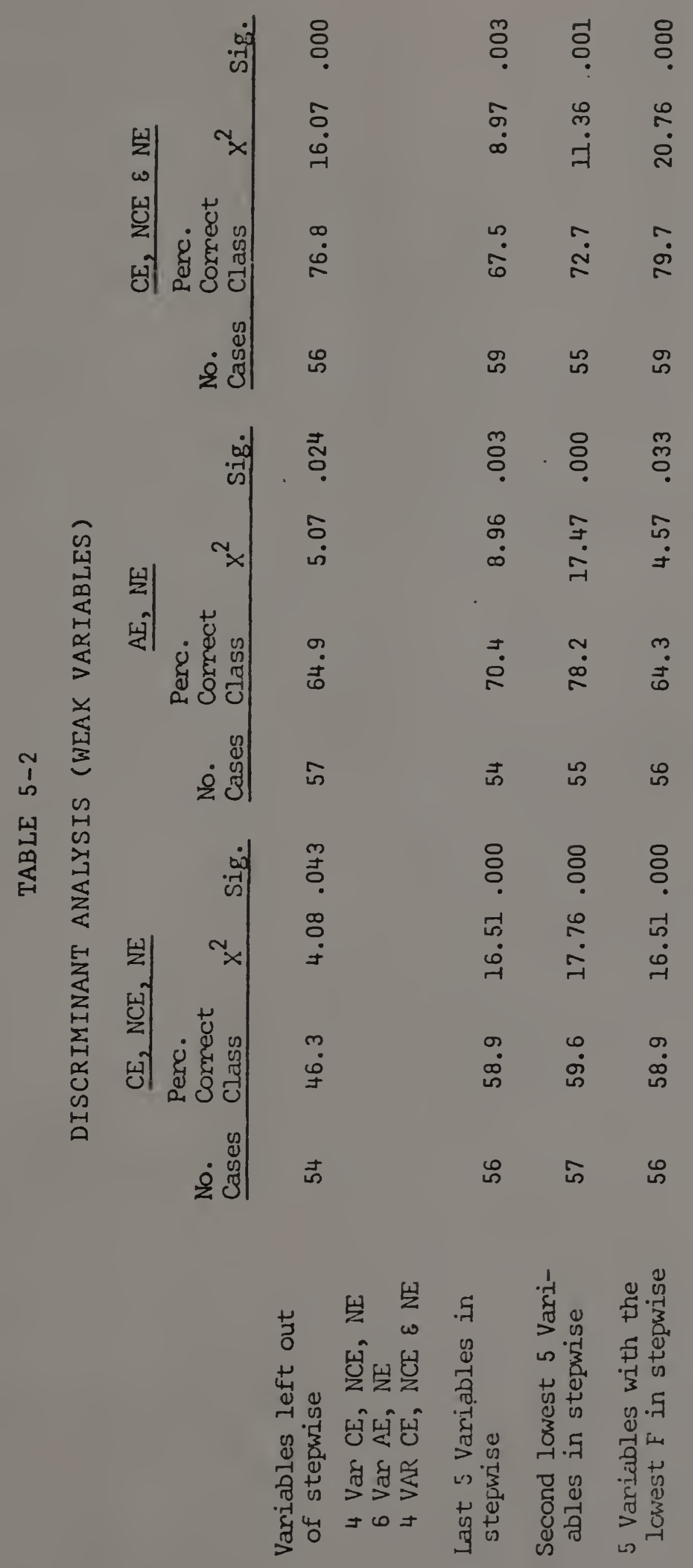


terion, and so forth. ${ }^{3}$ The first eight stepwise variables were used in the three runs: CE, NCE, NE; AE, NE; CE, NCE $\varepsilon N E$. The results, shown in Table 5-I, were all significant at the .000 level, and the percentage of correct classifications varies from 98.0 percent to 83.6 percent. Next the number of variables in the analysis was reduced in steps from eight, to four, to two, and finally to one. ${ }^{4}$ As would be expected, the percentage of correct classifications dropped, but all of the results were still significant at the .000 level. This could lead to the assumption that the first variable in the stepwise analysis, which was variable 23 in all three runs, was a very strong variable and that it overpowered the other variables in the analysis. In order to test this, another run was made using the second through the eight variables. The results, shown in Table 5-1, are still significant at the .000 level, and the percentage of correct classifications actually rose in one case, stayed about the same in another, and dropped in the third. One reason for the rise could have been the fact that in this instance more cases came into the analysis, and this may

\footnotetext{
${ }^{3}$ Nie et al., op. cit., p. 447.

${ }^{4}$ With one variable it is possible to develop only one discriminant function, and so it is impossible to separate the cases into more than two groups. Therefore, no data is available for the $\mathrm{CE}$, NCE, NE group.
} 
terion, and so forth. ${ }^{3}$ The first eight stepwise variables were used in the three runs: CE, NCE, NE; AE, NE; CE, NCE E NE. The results, shown in Table 5-1, were all significant at the .000 level, and the percentage of correct classifications varies from 98.0 percent to 83.6 percent. Next the number of variables in the analysis was reduced in steps from eight, to four, to two, and finally to one. ${ }^{4}$ As would be expected, the percentage of correct classifications dropped, but all of the results were still significant at the .000 level. This could lead to the assumption that the first variable in the stepwise analysis, which was variable 23 in all three runs, was a very strong variable and that it overpowered the other variables in the analysis. In order to test this, another run was made using the second through the eight variables. The results, shown in Table 5-1, are still significant at the .000 level, and the percentage of correct classifications actually rose in one case, stayed about the same in another, and dropped in the third. One reason for the rise could have been the fact that in this instance more cases came into the analysis, and this may

\footnotetext{
${ }^{3}$ Nie et al., op. cit., p. 447.

${ }^{4}$ With one variable it is possible to develop only one discriminant function, and so it is impossible to separate the cases into more than two groups. Therefore, no data is available for the CE, NCE, NE group.
} 
have changed the results. In any case variable 23, while admittedly a strong variable, did not seem to be solely responsible for the good results.

Weak variables. The next step was to look at the weak variables. The stepwise discriminant analysis computer program used in this study often leaves a few variables out of the stepwise program because they are so weak that they add nothing to the analysis. In this study the CE, NCE, NE and. the CE, NCE \& NE groups had four of these while the AE, NE group had six such variables. These were the weakest variables in the analyses, and so they were chosen for the next run. The results were very good. The CE, NCE, NE group had a 46.3 percent correct classification, and this was significant at the .043 level, well within the standard .05 classification. The others were even more significant. AE, NE had a 64.9 percent correct classification with a significance level of .024 , while for the CE, NCE \& NE group it was a 76.8 percent correct classification and a significance of .000 . In order to be sure that the trend continued, two more sets of runs were made. The first used the last five variables entered into the stepwise program, and the second used the next to last five variables entered into the stepwise program. The results, shown in Table 5-2, are all significant at the .003 level or better.

One final test remained. Because of the nature of the stepwise computer program that was used, certain variables, 
entered late in the analysis, are reasonably strong, and once they get into the analysis they "steal" from some of the other variables ahead of them. As a result, some of the variables in the last two runs were reasonably strong. The strength of the variable is indicated by a Wilks' lambda statistic, and it is tested with an F-test. Therefore, a final set of runs was made using the five variables in each set with the lowest (weakest) F statistic. The results are shown in Table 5-2 and are very strong with a statistical significance ranging from .033 to .000 .

The methods of testing described above were necessary because of the small sample size. If the sample had been larger, it could have been randomly split into two groups. Then the discriminant analysis could have been run on one half and the results applied to the second half to see how well the analysis predicted group membership. However, the size of the sample made such a plan impossible.

Summary of the Discriminant Analysis

The results of the discriminant analysis strongly supported the main hypothesis of the study that the decision makers of firms engaged in exporting differ from the decision makers of firms not engaged in exporting in their perception of such factors of exporting as risk, profit potential, costs, problems, and personal rewards. Although indi- 
vidually some of the statements do not appear to have predictive power, any group of variables that was tested predicted group membership far better than could have happened by chance. Most of the tests were significant at the .000 level, which means that there was no possibility of the results happening by chance. 5

In addition the results strongly supported the nonparametric results described in Chapter IV. This strongly reinforces the study because two different types of statistical techniques were used on the same problem. Although each approached the problem differently, both arrived at the same conclusion. Furthermore, even though the evidence is far from conclusive, in both types of analyses the noncommitted exporters generally appeared to behave more like the non-exporters than like the committed exporters.

${ }^{5}$ The results were, of course, subject to the assumptions of discriminant analysis and the limitations of this study, both of which were discussed in some detail in Chapter II. 


\section{H A P T E R VI}

\section{SUMMARY AND CONCLUSIONS}

\section{The Research Findings}

In recent years as the United States has struggled through a series of balance of payment crises, government officials, while noting that the average U.S. company exports only four to five percent of its domestic production in contrast to exports of twenty percent or more for many of the other leading industrial countries of the world, have sought ways to persuade American companies to increase their exports. This study was concerned with the reasons why some American firms export and others do not. Specifically, it investigated the question of whether the perceptions of the decision makers of companies engaged in exporting differed from the perceptions of the decision makers of firms not engaged in exporting toward such factors as the risks, profit potentials, costs, problems, and personal rewards of exporting. The study found strong support for the hypothesis that there is a difference in the way that exporters and non-exporters perceive these various factors.

The researcher used a sample of fifty-nine small Massachusetts manufacturers whose principal products were in six Standard Industrial Classification (SIC) groups previously identified as high technology industries. These SIC groups were chosen because studies have indicated that if the com- 
monwealth of Massachusetts is to grow and prosper in the coming decades, it must promote the continued growth and prosperity of its high technology industries, and as domestic markets become increasingly competitive, one possible way for these industries to continue to grow is for them to expand their export markets. The companies used in the study were located primarily in three large metropolitan areas (greater Boston, Worcester, and Springfield) with a few others scattered around the eastern and central part of the state. They ranged in size from twenty to three-hundred fifty employees.

A letter had been written to the chief executive of each of the companies asking for permission to interview the executive responsible for deciding which markets his firm would enter. This was done with the assumption that the person designated would be the executive who decided whether or not the company would export. The letter also suggested that in a small company, this individual would usually be the president or the marketing manager. The researcher interviewed the key decision maker suggested by the chief executive. The study found very little difference in the demographics of the decision makers of the exporting and the non-exporting companies. Most of them were either presidents of their companies ( 39 out of 59 ) or corporate officers (50 out of 59 ). Their average age was very similar ( 49.5 years for the exporters and 48.9 years for the non- 
exporters). Intuitively one might have thought that the exporters would be younger than the non-exporters and thus less prone to accept the status quo. This might have been true if the firms were all new companies with a new product line. However, this was not the case. Most of the exporters were old established companies, just as were the non-exporters. Many had been exporting for years, and often the exporting had been begun under the leadership of a decision maker now no longer with the company. The interviewer found no correlation between age and interest in new ideas, new products, and new distribution channels. One of the most active and enthusiastic export decision makers was sixty-five years old while some of the non-exporters who were under forty seemed to the interviewer to be much more set in their ways and less responsive to change or to new ideas. There was a wide range in the ages of the decision makers for both exporters and non-exporters, and age did not appear to be a factor in whether or not they were responsive to the opportunities to export.

The education of the decision makers in terms of formal schooling was very close ( 16.3 years for the exporters and 15.8 years for the non-exporters). Many of the decision makers had one or more college degrees, and most of these degrees were either in engineering or business. One of the minor hypotheses had predicted that there would be a significant difference in the educational level of the decision makers of the exporters and the non-exporters. While this 
had been found in other studies, it was not found in this one. This reason seems to be that this was the only study that concentrated on high technology companies, and in these high technology companies, a college education for the top level executives seems to be more of an asset than it is in some of the lower technology companies. Education in engineering and the sciences would intuitively seem to be more important in this group of companies, and it turned out that it was. Seventeen had engineering degrees, and several more had degrees in the physical sciences. Since other studies used a wider range of industries, it is quite possible that a difference in the educational level of the decision makers of exporters and nonexporters would be expected for those studies. This would be especially true if it should turn out, as this study seems to indicate, that a larger percentage of high technology firms export than do the low technology firms.

The other minor hypothesis predicted that there would be a statistically significant difference between the exporters who had made trips to foreign countries. This was not supported. The study found only two of the decision makers (one exporter and one non-exporter) had not made at least one trip to a foreign country. The general affluence of the United States and the increasing use of air transportation has made foreign travel much more common than in the past. Some of the travel of the executives was to resort centers in other areas of the world. While this does give the traveler a flavor slightly different from that 
found in the United States, it really does not throw him into contact with many people from other cultures in a manner that might change his perceptions about the problems of exporting. Most of his fellow guests will be other American tourists from similar economic status, and he will probably learn very little about the country he is visiting. Therefore, it would appear that a much narrower and more restrictive definition of foreign travel should have been used in order to eliminate the problem just discussed.

The study uncovered one unexpected result. Seven of the exporters, all of whom did only limited exporting, responded to questions in the interviews with answers that sounded more like the responses of the non-exporters in the study than like those of the exporters. These seven decision makers were classified as committed exporters. Two sets of tests were made in the statistical analysis. First, all exporters were compared with all of the non-exporters as originally planned. Second, the committed exporters were compared with a group made up of the non-committed exporters and the non-exporters.

Forty-nine statements about exporting were developed to test the main hypothesis of the study that the exporters and non-exporters differed in their perceptions toward the risks, profit potentials, costs, problems, and personal rewards of exporting. The decision makers were asked to rate each statement on a six point Likert type scale. At one end of 
of the scale he registered strong disagreement with the statement and at the other end strong agreement. In between there were milder terms of disagreement and agreement. Two methods were used to test the results. In the first method each statement was tested individually using a KolmogorovSmirnov nonparametric analysis. The test determines whether two individual samples have been drawn from the same population (or from populations with the same distribution). In the second method a multivariate discriminant analysis was used to determine whether the statements were able to discriminate between the two groups and to correctly classify the decision makers. In both types of analyses, the hypothesis was strongly supported. In the comparison using the committed exporters against the non-committed exporters and the non-exporters, the results were more positive than when all exporters were compared with the non-exporters. This would seem to indicate that in any attempts by change agents to increase exporting, all non-committed exporters, who can be identified, should be included with the non-exporters in whatever treatment is tried. The non-committed exporters are unwilling exporters, and until their perceptions toward exporting are changed, they will do as little exporting as possible.

A final analysis of the data was made using a factor analysis to see if it would be possible to isolate five or six factors that would explain most of the variance. These 
results were what one multivariate expert, Professor Donald G. Frederick, described to the researcher as a classic example of a case where factor analysis does not work. The determinant was nearly zero, and the inverse of the correlation matrix had some extremely high numbers in it. Although an examination of the correlation matrix showed no clear evidence of the source of the multicollinearity, there was multicollinearity present and, therefore, there was a linear dependence between several of the variables or groups of variables which would make any results suspect. Since the factor analysis showed no evidence of correlation between the statements, it was of no help in this study.

Change Agents and the Export Decision Makers

In Chapter II a change agent was described as a "professional person who attempts to influence adoption decisions in a direction he feels desirable." In this study the adoption decision is exporting. There are a number of public and private agencies whose avowed purpose is to act as a change agent by influencing companies to export. The federal government through its Department of Commerce is very interested in increasing exports for reasons discussed previously in this study. The Department of Commerce and Development of the Commonwealth of Massachusetts is committed to a policy of increasing exports. The International Center of New England, Inc. was established to promote the exports of 
New England manufacturers. In addition, a number of the state's larger banks and some of the Chambers of Commerce try at times to act as change agents as far as promoting exports is concerned.

What is the effect of these change agents on small Massachusetts manufacturers? If this study is any criterion, the answer is not very much. More than half of the companies interviewed had not heard of the International Center of New England, Inc., and none of those who had heard of it were using its services to any extent. One or two had attended one or more of its seminars but apparently had not felt that they were particularly helpful to them. One decision maker remarked during the interview that he used to pay his dues to the Center but had not paid them this year because he had not had occasion to use its facilities for more than a year.

The State Department of Commerce and Development had no impact on the companies visited. One decision maker said that a representative from the state was going to visit him the following week, but he did not know whether it was about exporting or not. Statement 9 on the sheet Opinions of Exporting reads as follows:

The Commonwealth of Massachusetts does nothing to help increase exports.

This statement usually elicited some comment from the decision maker when he read it, and his comment was usually far from complimentary. 
The United States Department of Commerce was the most widely applauded of the government change agents. The general comments of those who were familiar with the department's services were that this was an agency of the government that really cared about business. Many of the companies had received visits from the Department of Commerce field agents explaining its services. A number of the decision makers described the help which they had received on specific problems relating to exporting.

Although some of the larger banks have departments to help promote exporting, this study found no indication that any of the companies in this study had any contact with them except for the performance of routine banking functions. The same is true of the Chamber of Commerce and also other trade associations.

But there is interest in receiving help. When the matter of the use of change agents, particularly the Department of Commerce and the International Center of New England, was brought up in the interview several of the decision makers indicated an interest to the point of asking the interviewer for the addresses of one or both of these organizations and the name of people to contact there. It appears that perhaps the time is ripe for these change agents to try to help increase the exports from the Commonwealth. 
Policy Implications

For governmental change agents. For a number of years the United States government has been trying to increase exports. The Department of Commerce has expanded its field service, has conducted advertising campaigns to promote exporting, has sponsored trade shows at home, and has encouraged American firms to participate in trade fairs abroad. Congress has authorized the establishment of DISC corporations to allow a company to defer taxes on export profits, and still a large percentage of American firms do no exporting at all.

This study indicates that the reason many firms do not export apparently has more to do with the decision maker's perceptions of the risks, profit potentials, costs, problems, and personal rewards than with the actual factors themselves. If this is true, then perhaps the government change agents need to shift the emphasis of their programs. At the present time their aim is to make exporting easier, and they have done a splendid job of opening doors for companies that want to export. However, the decision maker, whose perceptions of the risks, profit potentials, costs, problems, and personal rewards of exporting are such that he "knows" that exporting is not for him, does not respond to the type of promotion now used by the department. He does not seek help from the Commerce Department because he 
has no intention of exporting. He probably does not read the Department's ads, or if he does, he complains about the waste of the taxpayers' money for such ridiculous advertising. Even a visit from a Department field representative probably will not change his mind. The Commerce man would be repeating the advantages of exporting and telling of the help available from the Department, while the decision maker would be saying to himself, "That's all right for other companies, but we can not compete in the export market." Therefore some other approach is necessary. It is not a matter of giving somebody the facts. Instead it is necessary to change the decision maker's attitudes. Bem, ${ }^{1}$ in a discussion of various methods of changing attitudes, says that interpersonal influence and following the lead of one's reference groups are two of the most effective ways of changing attitudes. This would indicate that government change agents might be more effective if they tried to work with fewer companies and spent much more time with each individual decision maker in order to establish a close interpersonal relationship and thus, possibly, be more effective in changing the decision maker's attitudes and perceptions of exporting.

The "Partners-in-Trade" program described in Chapter I uses this approach. The larger exporting firms in the pro-

${ }^{I_{\text {Daryl }} \mathrm{J} \text { Bem, Beliefs, Attitudes, and Human Affairs }}$ (Belmont, California: Brooks/Cole Publishing Company, 1970), PP. $70-88$. 
gram work closely with the smaller companies that are interested in exporting, acting like "big brothers" to guide the smaller companies over the early problems, real or imagined, of exporting. Once the decision maker of the small firm breaks through the psychological barrier he has built around the many problems of exporting, the job will be done and the company will be able to manage by itself. An example uncovered in this study concerns the paint company discussed in Chapter III. Apparently the decision maker's main concern, once the initial contact had been made, was the probIem of shipping. The American stain manufacturer, who initially stirred his interest in exporting, shipped his stain to Australia in containers, and he offered to pack the paint company's initial shipments in a container of stain that was then being shipped. As the paint manufacturer explained it to the researcher, "If it had not been for John Smith (not the correct name), we would never have bothered with all of the initial problems."

It is not reasonable to expect to find many companies willing to spend much time helping others at no cost to themselves, so if this is to be done on a large scale, some changes need to be made. In addition, in the case of both the "Partners-in-Trade" program and the paint manufacturer, the company has at least reached the point where it is interested in investigating the possibilities of exporting. This study indicates that most non-exporters have no real 
interest ir: exporting. Therefore, it would seem that the Eovernment change agents should attempt to ferret out the firms which, because of thein product line or sone other criterion, apparently should be exporting and spend a great deal of time trying to develop their trust so that eventually they can De persuaded to export. This would require a change in the operating policy of the department. At the present it is trying to serve all potential exporters, and this would require that it concentrate its efforts, initialIy at least, on a nelatively few companies. Once the compariy reached the point where it was really interested in exporting, some veriation of the "Pertnere-in-Trade" program would probajly be helpful. Ancther approach rnight be to try ard fird neference groupe that appeal to certain types of non-exporters and see if they could be enlisted to help to chenge the decizion makers' ettitudes. In either case, it appeare that it will be a loreg procese.

Eor the collegea ard universities. Oven the long run perhape the colleges erd universities offer the best point at winich to change these attitudea toward exporting. The moct irmediate efforto wight come from the various managewert development courese now being offered to executives. Ideally, coursez ebout exportireg, ito advantages and dieadvantages, with scme step by step approach to lead the executive through the procese, would beet. However, thie ctudy Indicetee that probably thie type of course nould rot at- 
tract the confirmed non-exporter. Therefore, in general management courses, some of the advantages of exporting should be stressed. If this second approach were used, the faculty involved in the management development program would have to be committed to the promotion of exporting, and this commitment is rare among most business faculties.

The long range educational policy indicated by this study concerns business school faculties and curriculum. Some educators, like some businessmen, are provincial in their thinking. The business schools should attempt to balance their faculties so that the role of international business is adequately presented to the students. Where appropriate, regular courses in accounting, finance, management, and marketing should deal with international as well as domestic business. Specialized courses in international business should be available to the students, and the larger schools should offer a major in international business. This is not a new issue but has been a concern of many business educators for some time. ${ }^{2}$ If all students were exposed

2"The International Dimension of Management Education," A Report by a Special Brookings Panel for the American Assembly of Collegiate Schools of Business in 1975 addresses itself to some of the same problems and arrived at the following conclusions:

The internationalization of business has so expanded international influences even on domestic business that all students of management should have a greater knowledge of these influences and how they affect business and management.

Schools seeking distinction in management on a global scale should staff themselves and organize their programs to 
to the various aspects of international business, perhaps they would not have the fears and misunderstandings found in many of the non-exporters in this study. Then as they graduate and go into business, they should have different attitudes and perceptions toward exporting than are possessed by many non-exporters today. As these men reach positions of authority in the firm, there should be a change in the perceptions toward exporting and, hopefully, more exporting. If this does work, then the changes should come with increasing rapidity. If Bem is right, and interpersonal influences and the influence of reference groups will change attitudes, then as a few firms begin to export successfully, their contemporaries may note their success and attempt to emulate it. For governmental policy makers. Up to now this discussion has assumed that no special incentives will be offered to companies that export, other than the very limited incentive offered by DISC. One very quick way to change perceptions would be to reduce drastically the risk of exporting or to increase drastically the profit potential. This can be done, but it would require a change in government

prepare qualified candidates for positions in MNCs and related enterprises.

Faculty members in several ways can acquire the knowledge, experience, and skills needed to deal with the globalization of business and to develop potential managers for international firms. Curriculum reforms and student interest must be encouraged. Diplomatic and executive experience enlisted from abroad can assist the effort. 
policy. The following areas offer opportunities. Although credit insurarce for export shipments is available in the United States, it is much more limited than government sponsored credit insurance available to most European companies. If the United States should offer credit insurance eclial in coverage and cost to the best offered by foreign governments to thein companies, this might help. U.S. companies are also at a disadvantzge when compared to many foreign companies in tems of long term financing of their expont shipnents. Most European companies can offer financing for periods up to five years at rates far below what the Americar firms car offer. This is becalise the European govemments underwite much of this financing and do it very quickly ard efficiently. By contrast, the Export-Import Bark in the Urited States ras a reputation for being very slow in epproving financing, and often after months of delays, it has been known to turr down a loan so thet e potentially profitable order is lost by an fmerican firm. In the meantime a Eurcpean company can ofter secure financing from its government for sale of the sare product to the same customer. This lack of govermertal urderstanding has discouraged many exponters and potertial exporters.

Tax incentives for export shipments is another possibility. Wost European ccuntries degend more on a value adced tay thar they do on an income tar. These countries often Eive a rebate of alI or part of these tayes or any goods 
that a company exports. This has the effect of drastically reducing the costs of goods that go into the export markets. Several of the exporters in this study mentioned this as a problem for them in meeting competition overseas. The United States has no such tax and rebates of income taxes could possibly lead to charges of dumping. However, if some tax incentives could be worked out, possibly with some combination of federal and state incentives, this should increase the profit potential from exporting and might help change perceptions.

If the United States should make some very drastic shifts in policy and offer sizable incentives similar to those just described, it is very possible that this would force many non-exporters to reevaluate their thinking and perhaps might start them exporting. Small changes probably would not do this, but large ones might.

\section{Implications For Future Research}

This was an exploratory study, and as such its main purpose was to break the ground for further research. Very few studies have looked into the reasons why some small companies export and others do not. None has used the approach of this study, borrowed from buyer behavior, that views exporting as a product which change agents are trying to sell to the decision makers of various manufacturing companies, and that then tries to test the decision makers' perceptions of the 
"product."

The research shows that the method is feasible, and it strongly supports the main hypothesis of the study that

The perceptions of the decision makers of firms engaged in exporting toward such factors of exporting as risk, profit potertial, costs, problems, and personal rewards differ from the perceptions toward these factors of the decision makers of firms not engaged in exporting.

Inerefore, further research should be conducted to test the hypothesis on a bider scale. Depending on available funds, this could be done lising either a regional or national sample. F research design using personal interviews would allow greater flexibility in questioning; however, a satisfactory mail survey could be developed. A random sample of several nundred finms sriculd be used so that the researcher would almost certainly $b \in$ assured of having enough exporters and non-exporters to insure meaningful results. If a mail survey should be decided upor, only exporter and non-exporter classiEications could be used, since the comnitted, non-comnitted exporter ciassification deperds on the interviewer's evaluation after talkirg to the decision maker. The research instrumerte would have to be reviewed ard revised as necessary, but no drastic changes would be required. If the results of the exploratory study should be replicated in an enlarged study such as has been envisioned in this section, it would greatly erhance the value of this research and would have 
much more meaningful implications for public policy. If the results were not replicated, then both studies would need to be examined very carefully to try and determine the reasons for the difference in the outcomes.

Another interesting possibility suggested by this research would be to replicate the study in one or more foreign countries. This would allow the researcher to determine whether the phenomenon observed in this study is a national or an international one. Such a study would present a number of difficulties. The most important is probably the problem of language. All research instruments would need to be carefully translated into the language of the country being studied. In addition, the statements about the opinions of exporting were drawn up with Americans in mind and would have to be examined carefully to be sure that they are applicable to the country in which they are to be used. These problems are not insurmountable, but they would require careful attention.

This research uncovered two types of exporters, committed and non-committed. Since the non-committed exporters behaved more like the non-exporters than like the committed exporters, any effort at increasing exporters which is aimed at the non-exporters should also be aimed at the non-committed exporter. The problem is that there is no way to easily detect him. Therefore, a study to find out more about the non- 
committed exporter might give the government change agents some clues that would make it easier to identify him. 


\section{BIBLIOGRAPHY}

"After one year, benefits of DISC are still not clear." Industry Week, Vol. 176, No.9 (February 26, 1973), PP. 22-25.

"Agent Distributor Service Now Going Worldwide." Commerce Today, Vol. 3, No. 11 (March 5, 1973), pp. 12-13.

Ashton, David J. New England Manufacturers and European Investments. Research Report to the Federal Reserve Bank of Boston, No. 23, Boston, Massachusetts, 1963.

- New England Manufacturers' Export Practice and Potential. Research Report to the Federal Reserve Bank of Boston, No. 9, Boston, Massachusetts, 1960.

- The Meaning of Export Origin. Research Report to the Federal Reserve Bank of Boston, No. 10, Boston, Massachusetts, 1960 .

Bem, Daryl J. Beliefs, Attitudes, and Human Affairs. Belmont, California: Brooks/Cole Publishing Company, 1970.

Boyd, Harper W., Jr., and Westfall, Ralph. Marketing Research, 3rd edition. Homewood, Illinois: Richard D. Irwin, Inc., 1972 .

"Broad view of trade issues urged by departing Peterson." Industry Week, Vol. 176, No. 5 (January 29, 1973), pp. 25-26.

"Businessmen's Awareness and Attitudes Toward Exporting and Exporting Promotional Efforts, Phase II." Report to the Bureau of International Commerce of the U.S. Department of Commerce. Princeton, New Jersey: Opinion Research Corporation, 1972 .

Chacholiades, Miltiades. The Pure Theory of International Trade. Chicago: Aldine Publishing Company, 1973.

Clifton, John P. The Formulation of Effective Small Business Strategy: A Case Study Presentation. Small Business Administration Research Report Number 50. Manhattan, Kansas: Department of Industrial Engineering, Kansas State University, 1961.

"Despite Devaluation, Federal Aid, There's No Boom in Exporting." Industry Week, Vol. 177, No. 5 (April 30, 1973), PP. $70-74$. 
"District Offices Aid Business." A United States Department of Commerce Publication. Revised May, 1973.

Dowd, Laurence P. Principles of World Business. Boston, Massachusetts: Allyn and Bacon, Inc., 1965 .

"Eximbank's Full Service for Exporters." Industry Week, Vol. 174, No. 11 (September 11, 1972), pp. 46-53.

Exporting Marketing for Smaller Firms. 3rd edition. Washington, D.C.: Small Business Administration, 1971.

"Exporter Supply Some Hope On Trade." Business Week, No. 2274 (April 7, 1973), pp. 20-21.

"Export Markets Targeted for U.S. Industry." Commerce Today, Vol. 2, No. 20 (July 10, 1972), pp. 35-37.

Farmer, Richard N. International Management. Belmont, California: Dickenson Publishing Co., Inc., 1968. . "There Are Holes In The Free Trade Argument," Issues In Business And Society, edited by George A. Steiner. New York: Random House, 1972.

Fayerweather, John. Facts and Fallacies of International Business. New York: Holt, Rinehart and Winston, 1962 . - Management of International Operations. New York: McGraw-Hill Book Company, 1960.

Getting Started In Export Trade. Geneva, Switzerland: International Trade Centre, 1970.

Green, Paul E., and Tull, Donald S. Research for Marketing Decisions, 2nd edition. Englewood Cliffs, New Jersey: Prentice-Hall, Inc., 1970.

Hazard, John L. Michigan's Commerce and Commercial Policy Study. East Lansing, Michigan: MSU International Business Studies, 1965 .

Hill, 0. Mary, ed. How To Win World Markets. Ottawa, Canada: Department of Trade and Commerce, 1967.

Kearns, Henry. "A Golden Age for U.S. Exporters," Columbia Journal of World Business, Vol. 8, No. 3 (Fall 1973), PP. $113-115$.

Kerlinger, Fred N. Foundations of Behavioral Research. New York: Holt, Rinehart and Winston, Inc., 1964. 
Kindleberger, Charles P. International Economics, 4th edition. Homewood, Illinois: Richard D. Irwin, 1968.

- Foreign Trade and the National Economy. New Haven, Connecticut: Yale University Press, 1962.

- Power and Money. New York: Basic Books, 1970.

Kolde, Endel J. International Business Enterprise. Englewood Cliffs, New Jersey: Prentice-Hall, 1968.

International Monetary Fund. Balance of Payments Concepts and Definitions. Washington, D.C.: International Monetary Fund, Pamphlet Series, No. 10, 1968.

Levitt, Kari. Silent Surrender. New York: Liveright, 1970.

McCarthy, E. Jerome. Basic Marketing, 5th edition. Homewood, Illinois: Richard D. Irwin, Inc., 1975.

McKenna, Joseph P., and Boyle, Stanley E. The Participation of Missouri Firms in Export Trade. Small Business Management Research Report. St. Louis, Missouri: St. Louis University, School of Commerce and Finance, 1961.

Marks, Eli S., and Hyman, Herbert. American Businessmen and International Trade. Glencoe, Illinois: The Free Press, 1960 .

Massachusetts Industrial Directory 1974-75. Boston, Massachusetts: Department of Commerce and Industry.

Nehrt, Lee C. Financing Capital Equipment Exports. Scranton, Pennsylvania: International Textbook Co., 1966.

Neidell, Lester Allan. Comparative Export Practices of Small Firms in the United States and Scandinavia. Research Report to the Federal Reserve Bank of Boston, No. 29. Boston, Massachusetts, 1965.

- "U.S. and Scandinavian Export Practices Compared," New England Business Review, (September 1965), pp. 10-13.

Nie, Norman H.; Hull, C. Hadlai; Jankins, Jean G.; Steinbrenner, Karin; and Bent, Dale H. SPSS: Statistical Package for the Social Sciences, 2nd edition. New York: McGraw Hill Book Company, 1975.

"Partners Offer Export Help to Small Firms." Industry Week, Vol. 176 , No. 5 (January 29, 1973), pp. $24-25$. 
Peterson, Peter G. The United States In The Changing World Economy. London, England: British North American Research Association, 1972 .

Pinney, James $K$. "The Process of Commitment to Foreign Trade: Selected Smaller Indiana Manufacturing Firms." Unpublished DBA dissertation, Indiana University, Graduate School of Business, 1968.

Rhodes, John B. "Upturn in Foreign Activity by U.S. Business," Columbia Journal of World Business, Vol. 8, No. 2, (Summer 1973), Pp. 19-24.

Rieth, Ralph A., Jr. "Massachusetts International Position." Unpublished report.

Robinson, Richard D. International Business Management, A Guide to Decision Making. New York: Holt, Rinehart and Winston, Inc., 1973.

Robock, Stefan H., and Simmonds, Kenneth. International Business and Miltinational Enterprises. Homewood, Illinois: Richard D. Irwin, Inc., 1973.

Rogers, Everett M. Diffusion of Innovation. New York: The Free Press, 1962 .

Rogers, Everett M., and Shoemaker, F. Floyd. Communication of Innovations, 2nd edition. New York: The Free Press, 1971.

Root, Franklin R. Strategic Planning For Export Marketing. Scranton, Pennsylvania: International Textbook Co., 1966 .

Servan-Schreiber, J.J. The American Challenge. New York, Atheneum, 1968 .

Siegel, Sidney. Nonparametric Statistics for the Behavioral Sciences. New York: McGraw Hill Book Company, 1956.

Simpson, Claude L., Jr. "The Export Decision Process: An Interview Study of the Decision Process in Tennessee Manufacturing Firms." Unpublished Ph.D. dissertation, Georgia State University, School of Business Administration, 1973 .

Sorenson, Ralph Z. "As I See It," Forbes, Vol. 110 (August $15,1972)$, pp. $54-56$. 
"Small Business Can Be Exponters, Agercy Declares." Commence Ioday, No1. 2, 110. 23 (Lugust 21, 1972), p. 21 .

"Small Finms Eind 'Partrers' Program Helps Export Sales." Incustry viekk, Vol. 178, lio. 8 (August 20, 1973), pp. $10-12$.

"Small Eirms to Eet Bcost Into Exporting Erom Eiants." Courerce Ioday, Vol. 3, 110. @ (Eebruary 5, I973), p. 38 .

"Stall Firm wins With Exports; Finds lleeded Help Is There." Incustry Week, Vol. I73, 10 . II (June I2, I972), Pg. $21-23$.

Special Brookings Panel. Report of the PaneI. The Intennational Dimension of Management Educaticn. Washingtor, D.C.: The Brookings Institution.

"States Step Up Business Prcmotion Abroad." Commerce Today, Vol. 3, No. 14 (Apriz 16, 1973), pp. 27-28.

Togenson, Warren S. Treory and Methods of Scaling. lisw Youk: John kiley and sons, Inc., 1958.

"U.S. Competitive Position Aided by Currency Snifts." Commerce Ioday, Vol. 3, lio. Io (Jure 25, 1973), P. 38 .

Gasson, Chester R. Corsurer Behavior, L Kanagerial Vienpoint. Austin, Texas: Áustin Educetional Division of Lone Star Fublishers, Inc., 1975 .

Weiner, Faul, and Krok, Wicreel. A Study of the Attempts and Results of Directly Stimulating Exporting . Reseanch Report to the Federal Reserve Bank of Eoston, No. 38 . Boston, Yassachusetts, 1967 . 
AFPENotx A 


\section{OPI ICNS CF CSOONDING}

The stitements listez helow are coiniors of exportinz or of the results or conseguerces of exrortirz. For each statement Iisted. we would like tr krow whether you axree or disazree with the statement. There are no riaht or wronz answers. Since we are only lnokine for your orinion, please irilcate it for each statement, even where you have limited information.

After eacr statement thern aro six rumbers, 1-6, the HIJHEF the number, the more you tent to $4 \mathrm{JEE}$ with tre statement. The ridhers from $1-6$ may be described is follows:

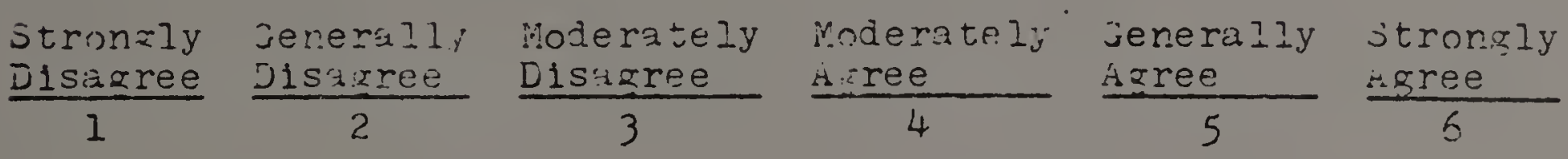

For each statoment, please c1rale the number that host describes jour fesilnss about the statement. you may trirk tinat many of the statements are similar. Actually no tio staterents are exactiv alike, so be sure to circle one number for eacr statement.

1. Exporting is very risky. I'I rather =0 to the racetrack. Then at least I coild have a rood time while I lost $\pi y$ money.

$123: 56$

2. Essentially exportirz is not differert from sellins ir. the donestic nariet.

123455

3. تxxortinx is very ifficult because tro most tesirable rarkets rave hizh tarlif barriers.

123456

4. Products utillzing new or idvanced technolory are ezsier to export than are produets usirz older ard more simple tecrinology

5. I look on exportine as a real challenze to my manaxerial capabilities.

6. A small firm is at a great disadvantare in exporting because of limited capital.

7. If we export, I would expect that overseas agents inoild be recdily availarile to handle our prodilits.

8. The paperwork involvet in exoortinx is too complicate: and expensive for our compary.
123456

123456

123456

123456

123456 
stronkly jen raliy Ootarately dolemal jenerally stronoly

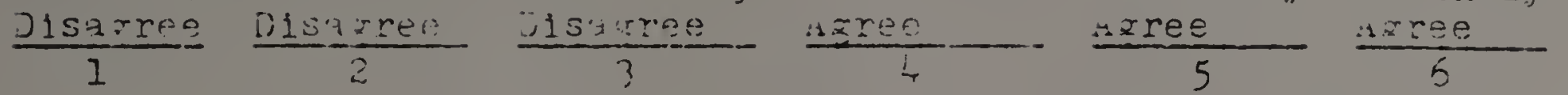

9. The Unmonweiltr of rasischisetts does rotoinic to ralp increase cexports.

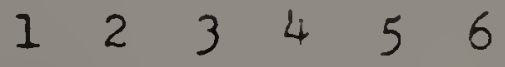

10. Inowione of the lancuate of a country

is imocrant in expontirit to that country. 1233456

11. The comollcstichs of ncear shipplng are so rreat trat exporting is rot a worthwhile vemtire inr a smill company.

123455

12. It is recessary to chenof sur product snecificatiorsi for virious export rézirets.

12534556

13. I don't soea'x inv Iangurge sut English and therefore vould be reluctant to try ant ant into tie exoort rusiness.

14. The politicul is:stuhility in the world makes it very risiry to enrige in export business.

$123 \quad 3 \quad 4 \quad 56$

15. Ne are at a disadvirtare wher comoarel

to Eurnoein exvorters because they recelve tax $r-f$ tes on their exports.

12234556

16. The muItinations ls have ruined the exoort busines: by ooenine plarts in rost of my best potertial maryets.

17. Exporting is not as reivarilne as dealinx Nith ry dorestia custoners.

18. Exportine is a sood way to comoensate for excess oroduction cavicity.

19. Fresilert Ford talks thout warting to increase exoorts, but the xoverrmert loes nothing to helo re in this reserd.

123456

20. I would like to exocrt, but I dor't kno's where to zo for helo.

$123 \quad 4 \quad 56$

21. Foreion travel is advantaxeous in gettirs into the export busiress.

$123 \quad 3 \quad 4 \quad 56$ 


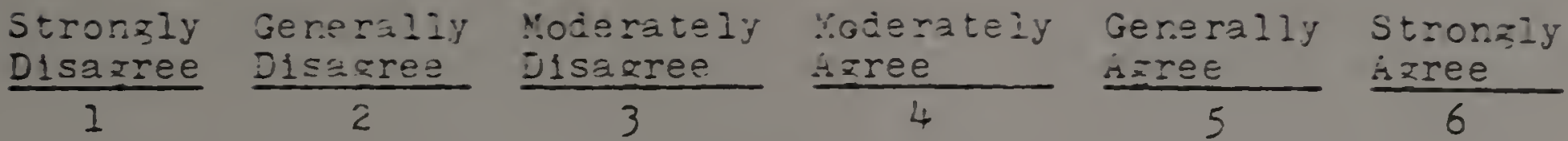

22. Export business is $\equiv$ ruisarce and

srould tincerore provide an extra

warzin o: wrifit when conoared

with dozisic business.

123456

23. He zust start exportirg now if our

comeary is zoir:z to cortinue to

zro'i.

123456

24. Exportinz is a very viatle method of increasing sales for a stall co=pary.

123456

25. Exporting is i1fricult lecause it is hard to chech creilit refereroes in foreizr ccuntries.

123456

26. f. dorestic international sales corroration, (DIS ), is a tie helr, ir: increasine the crafitability of our export business.

123456

27. Exporing zives me a crance to travei and leet peosle I could never neet in ary otirer kay.

123456

28. The zovernxent is orly interested 1r. ils business. Its prozrars to ald exports, such as DISC, are seared to the larze corporations and are too complicated and expersive for a small company.

123456

29 Particioation in a traje rair is a zood way to start or to expard an export market.

$123 \quad 3 \quad 4 \quad 56$

30. The company with a ranazer vic has had cormal traininz in internationa? business can do a retter job in exporting.

123456

31. The advent of tre European Comacr.

Market has rade exportinz to Europe

a very jifficult process.

$123 \quad 3 \quad 4 \quad 56$ 
itronely Generally Moderately Moderately

Disazree

1

Disazree

2

D1sazree

3

Axise

32. Exporting offers sienjilcant opcortunities for increasei orefits.

33. If we export, we will have to wa1t a Iong time for our monev.

34. We are at a disadvantare Nren compared to Europear exporters cecause they have government suonsored credit insurance.

35. Exportinx is difficult because many of our products are more expensive than forelen oroducts.

36. I feel that the contacts I could make in exporting would give re a better understandine of the prohlems of tree world.

37. Exportine reans extra problems because we must adi people with soecial

expertise.

38. We have all the inmestic hus iness we can handle, and therefore. I am not interested in exportins.

39. There is a large potent1al market for our proluct in forelon courtries.

40. Exporting 1s only for larker iris.

41. The U.S. Department of Commerce has a nuraber of good proaritis to heln small business get into exportinc.

42. Exporting offers me a mamsement speclalty that I feel could help solidify my position with the corouny.

43. Forelgn exchance probleris make exporting dirricult.

44. Exporting could be a prorltable outlet ror our rroduct.
Generally Stronzly

$\frac{\text { Azree }}{5} \frac{\text { freses }}{6}$

123456

123456

123456

123456

123456

123456

123456

123456

123456

123456

123456

123456 


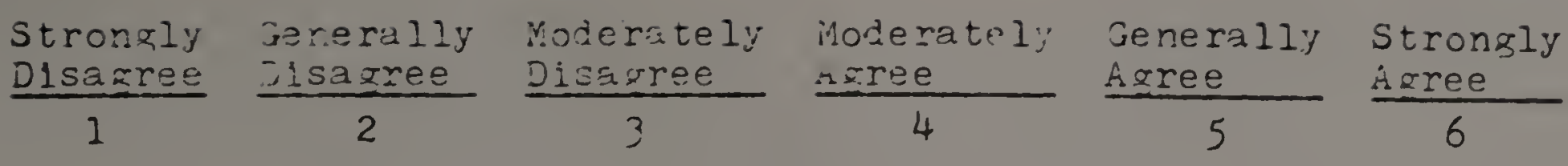

45. If a small firm tries to go into exDortins, it will ilnd that its avaliable executive talent will be spreat too thin, and the compary's overall performance bill suffer.

$1253 \quad 4 \quad 5 \quad 6$

46. We plan to increase tre percerture of our nroduct exported every year in order to attiin our desired rrcitr. rate.

$1223 \quad 4 \quad 5 \quad 6$

47. The extra volume which comes trrough exporting allows $z$ compary to imnlemert many production efficiencies.

$1 \quad 2 \quad 3 \quad 4 \quad 56$

43. College tralned rir'etinz executives are necessary if a company is considering entering the export market.

$1 \quad 2 \quad 3 \quad 4 \quad 56$

49. Since exporting means doing business under many differeve laws, tris increzses the complexity of marazement's problems to the point wrere it is inadvissible for a small company to consider seling outside of the domestic market. 


\section{APPENDIY B}




\section{INTERVIEW GUIDE SHEET}

1. Company Name:

2. Address:

Telephone:

3. Individual Interviewed:

\section{Title}

4. Date Company was started:

5. Type of business structure: corporation, partnership, individual proprietorship,__other (specify)

6. If business is a corporation, is the company closely held, publicly held, a division of

7. Are any of the major owners active in the business?

8. If yes, in what capacity?

9. Total number of employees?

10. Principal Products?

11. Do any of these products require a technology which is not readily available? Or are your products or your technology protected by patents?

12. Do you export? If no, skip to question 21. If yes, which products?

13. Approximately what percentage of your total sales were exported in 1974 1973 .1972

14. What countries do you export to?

Canada?

Latin America?

Western Europe?

Other?
Middle East?

Australia \& New Zealand?

Far East (incl. Japan)?
Eastern Europe \& Soviet Union?

Africa? 
15. When did you begin exporting?

16. Why? Received an export inquiry?

Had teinporary excess production?

Decided to expand market?

U.S. Department of Conmerce ads?

Attended foreign trade fair?

Higher profit potential?

Other?

17. Are you familiar with government sponsored credit insurance and with Domestic International sales Corp. (DISC)?

18. If yes, are you using either of these? If yes, what has been your exw perience?

If no, why aren't you using?

19. If answer to 17 is no, explain them briefly and then ask if he believes that either of these two programs would be beneficial for his company.

20. Would you describe some of the principal benefits and some of the principal problems which you have experienced as a result of exporting?

Benefits?

Problems?

Skip to question 27 . 
21. Have you ever exported? If yes, why did you stop?

22. What countries did you export to?

23. What are your reasons for not exporting?

24. Are you familiar with government sponsored credit insurance and with Domestic International Sales Corporations, (DISC)?

25. If yes, do you think that eitir has any value for a small corporation which wants to export?

26. If answer to guestion 24 is no, explain briefly and then ask question 25 again.

27. Are you familiar with the International center of New England, Inc.?

28. If answer to 27 is yes, do you feel the Center is beneficial to the region? Why or why not?

29. If answer to question 27 is no, explain briefly the purpose of the Center, and then ask if be feels this might be valuable to small Nassachusetts manufacturers. 


\section{PERSOLIAL DAIA ON MANAGEHENT INVOLVED IN EXPORT DECISIONS}

1. liame: Title:

2. Age:

3. Education: Total yeare of school completed?

Degrees and major if college graduate?

4. Do you read or speak a foreign language?

5. If so, which ones? (Indicate readinf and/or speaking ability.)

6. What are your areas of responsibility in the company?

$\%$. siave you traveled outside of the country?

8. What countries did you visit? when? for how long? purpose of trip?

9. How often do you feel the need to call on your overseas arients and customers? 
APPENDIX C

THE KOLMOGOROV-SMIRNOV TWO SAMPLE, ONE-TAILED TEST

\section{Introduction}

The Kolmogorov-Smirnov two-sample test is used to determine whether two independent samples have been taken from the same population. ${ }^{1}$ The one-tailed test is used when one wants to determine whether the values of the population from which one of the two samples was drawn are stochastically larger than the values of the population from which the other sample was drawn, i.e., to test whether the perceptions of the problems involved in exporting is greater for non-exporters than for exporters.

There are two Kolmogorov-Sminnov two-sample, one tailed tests. One is for small samples, and the other is for large samples. The small sample test requires equal size samples and is recommended for pairs of samples up to forty in number. The large sample test does not require equal sample sizes and is recommended for pairs of samples larger than forty. Siegel says that the large sample test may be used with small samples but that it leads to a conservative test. The more conservative two tailed test was chosen for this study because of the likelihood that there would be an unequal number of exporters and non-exporters.

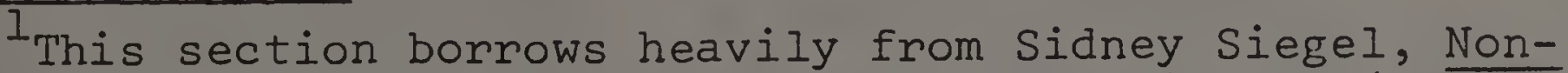
parametric Statistics for the Behavioral Sciences (New York: McGraw Hill Book Company, 1956), Pp. 127-136.
} 
The Test

It has been found that the large sample test has a sampling distribution which is approximated by the chisquare distribution with two degrees of freedom so that -

$$
x^{2}=4 D^{2} \frac{n_{1} n_{2}}{n_{1}+n_{2}}
$$

has a sampling distribution that approximates a chi-square distribution with two degrees of freedom.

Where

$$
\begin{aligned}
D= & \text { the largest cumulative difference between } \\
& \text { the exporter's and non-exporter's response } \\
& \text { distributions. } \\
\mathrm{n}_{1}= & \text { number of subjects in group one } \\
\mathrm{n}_{2}= & \text { number of subjects in group two }
\end{aligned}
$$

An Example

Using hypothetical responses to the following state-

\begin{tabular}{|c|c|c|c|c|c|}
\hline \multirow{2}{*}{$\begin{array}{l}\text { Question } \\
\text { Response* }\end{array}$} & \multicolumn{2}{|c|}{ Exporters } & \multicolumn{2}{|c|}{ Non-exporters } & \multirow{2}{*}{$\begin{array}{l}\text { Cumulative } \\
\text { Difference of } \\
\text { Percentages }\end{array}$} \\
\hline & $\begin{array}{l}\text { No. of } \\
\text { Resp. }\end{array}$ & $\begin{array}{l}\overline{\text { Cum. }} \\
\text { Percent }\end{array}$ & $\begin{array}{l}\text { No. of } \\
\text { Resp. }\end{array}$ & $\begin{array}{l}\text { Cum. } \\
\text { Percent }\end{array}$ & \\
\hline 1 & 8 & 32 & 0 & 0 & 32 \\
\hline 2 & 5 & 52 & 2 & 8 & $44-\operatorname{Max}$ \\
\hline 3 & 3 & 64 & 5 & 28 & 36 \\
\hline 4 & 5 & 84 & 5 & 48 & 36 \\
\hline 5 & 4 & 100 & 8 & 80 & 20 \\
\hline 6 & $\underline{0}$ & 100 & $\underline{5}$ & 100 & 0 \\
\hline Total & 25 & & 25 & & \\
\hline
\end{tabular}
ment:

Exporting is very difficult because many of our products are not competitive with foreign products.

The Kolmogorov-Smirnov analysis is shown below. 


$$
x^{2}=4(.44)^{2} \frac{625}{50}=.7744(12.25)=9.49
$$

The probability associated with chi-square $=9.49$ for $\mathrm{df}=2$ is $\mathrm{p}<.01$, and the null hypothesis would be rejected in this case. 
APPENDIX D 
Dear Mr.

I am a graduate student at the University of Massachusetts, working on my PhD in Marketing at the School of Business. My dissertation is a study of small Massachusetts manufacturers who employ twenty to five hundred people. In order to complete this study, I need to interview the person in each firm who is responsible for deciding which markets his firm will enter. In many small firms this would be either the chief executive or the marketing manager, although this is not necessarily so.

Recently when I was discussing my plans with Mr. Louis Camarra, Vice-President of the Norton Company and the Worcester area representative of the Department of Commerce District Export Council (DEC), he suggested that you might be willing to participate, and I would like to include your company in my survey. If you participate, any information I receive will be strictly confidential, and the final report will not reveal any individual company information. During preliminary testing of my methods I found that I spent an hour to an hour and fifteen minutes for each interview.

I will telephone you next week to talk to you further about this.

Sincerely,

Ralph A. Rieth, Jr. 
Dear Mr.

I am a graduate student at the University of Massachusetts, working on a PhD in marketing at the School of Business. My dissertation is a study of small Massachusetts manufacturers who employ twenty to five hundred people. In order to complete this study, I need to interview the person in each firm who is responsible for deciding which markets his firm will enter. In many small firms this would be either the chief executive or the marketing manager, although this is not necessarily so.

Recently when I was discussing my plans with Dr. Ernest J. Enright, Director of Research at the International Marketing Institute of Cambridge, he suggested that you might be willing to participate, and I would like to include your company in my survey. If you participate, any information I receive will be strictly confidential, and the final report will not reveal any individual company information. During preliminary testing of my methods, I found that I spent an hour to an hour and fifteen minutes for each of the interviews.

I will telephone you in a few days to talk to you further about this.

Sincerely,

Ralph A. Rieth, Jr. 
Dear Mr.

I am a graduate student at the University of Massachusetts working on a PhD in marketing at the School of Business. My dissertation is a study of small Massachusetts manufacturers who employ twenty to five hundred people. In order to complete this study, I need to interview the person in each firm who is responsible for deciding which markets his firm will enter. In many small firms this would be either the chief executive on the marketing manager, although this is not necessarily so.

I would like very much to include your company in my survey. If you do participate, any information I receive will be strictly confidential, and the final report will not reveal any individual company information. During preliminary testing of my methods, I found that I spent about an hour for each interview.

I will telephone you in a few days to talk to you further about this.

Sincerely,

Ralph A. Rieth, Jr. 
Dear Mr.

I am a graduate student at the University of Massachusetts working on a PhD in marketing at the School of Business. My dissertation is a study of small Massachusetts manufacturers. In order to complete this study, I need to find companies who do not export and who employ twenty to five hundred people. I would like to interview the person in each of these firms who is responsible for deciding which markets his firm will enter. In many small companies this would be either the chief executive or the marketing manager, although this is not necessarily so.

If your company falls within this size range and does not currently export, I would like to include it in my survey. If you do participate, any information I receive will be strictly confidential, and the final report will not reveal any individual company information. During preliminary testing of my methods, I found that I spent about an hour for each interview.

I will telephone you in a few days to talk to you further about this.

Sincerely,

Ralph A. Rieth, Jr. 


$$
\text { APPENDIX E }
$$




\section{APPENDIX E}

\section{COMMENTS FROM DECISION MAKERS ABOUT THE REASONS THEY BEGAN}

TO EXPORT

A belief that the growth in textiles would be largely outside the United States. (Textile machinery rebuilder and manufacturer)

It is getting to be a small world. Their products had worldwide application. They had associations with U.S. contractors with world-wide products, so they needed to protect their product line on a world-wide basis. (Blower and turbine manufacturer)

Profit opportunity. They see an explosive world-wide opportunity. (Data processing accessory files manufacturer)

We knew the market potential was there. (High quality electrical cable manufacturer)

To sell more products. (New and rebuilt printing machinery manufacturer)

To preempt the foreign market and gain product acceptance. (Analytical instrumentation manufacturer)

To secure extra business. All countries have textile industries. (Textile machinery parts manufacturer)

To expand market. (Comptuer graphics manufacturer)

To secure increased sales and profits. A desire to grow. (Electrical connectors and switches manufacturer)

Advertised in the United States and received a lot of foreign inquiries. Sold first to a United States exporter, i.e., domestic business, and when he died the company used export managers who set up agents all over the world. (Laboratory equipment manufacturer)

Received inquiries first from Canada and then from Germany. The Redwood Association recommended the company to Australian firms. (Paint and stain manufacturer)

To expand markets. To make money. (Vacuum pumps and accessories manufacturer) 
We had a unique product, and although we originally received unsolicited orders, we decided in the mid 1960's to cover airlines, railroads, and postoffices world-wide. (Manufacturer of computing terminals for airlines, theaters, and so forth)

American customers licensed European manufacturers who then came to us. (Semi-conductor components manufacturer)

Owners liked to travel. (Photo equipment manufacturer)

Need volume as business has very high breakeven point. (Artificial tooth manufacturer)

Bought out a customer who did a very large export business. (Special packaging machinery manufacturer)

Started servicing the European subsidiaries of its American customers. (Precision machining subcontractor) 


\section{APPENDIX F}




\section{APPENDIX F \\ REASONS GIVEN BY NON-EXPORTERS FOR NOT EXPORTING}

Our product is too bulky and heavy to ship any distance, either domestically or abroad.

Up to now we have had enough domestic business but are having an export marketing survey done now.

They did not have the know-how when they could have used the business, but now they are so busy with their domestic business that they really do not have the time. They expect that the situation will change. They may enter into a cross licensing agreement with an English company in the near future.

They have shipped their product (molds) to domestic customers who then shipped them overseas. They are now investigating the prospects of exports to India and to other countries.

Marketing reach. Lack of knowledge and the distances involved.

It is expensive for a small company. Business is becoming more competitive. There is no monopoly on technology. They are currently negotiating with a German division of an American multinational for an order. They feel that they may now be competitive with the devaluation of the dollar and the increasing standard of living abroad.

Lack of exposure. Business is extremely competitive; i.e., why would a European company be interested in buying subcontracted parts in Massachusetts.

They have never sought export business but will quote and ship overseas if they get inquiries. They have quoted England, France, and Mexico on extruder dies for plastics but have received no business as yet.

They are open to export business but will not pursue it as they have all the domestic business they can handle. They will accept an export order if approached. Sometimes a domestic customer has a foreign plant or licensee, and this results in an order. He says that since he really does not have a product, the solicitation of export business would be a problem, i.e., time consuming and costly. 
They would like to export, but their product (shovels) is a very basic product which can be made in other countries and usually made cheaper. They have shown at trade fairs and received a few orders. In addition a foreign agent representing a local tool manufacturer has gotten some business for them.

Their products are readily available elsewhere.

They have limited their market to New England and New York. Their product (steel doors and frames) is custom designed with few standard items. It is bulky and heavy so that freight charges become a high percentage of the cost when the product is shipped a long distance.

Up to now they have not been competitive on export shipments although they may be now since the dollar devaluation. However, they now have all the domestic business they can handle.

He feels it is better for him to do business with people he can contact personally. He says that many more screw machine products (his type) are imported into this country than are exported. They come mainly from Japan and Switzerland.

He says they are really selling labor, materials, and lead time. No one is carrying inventories, and their main market is within two-hundred miles of their plant. (Product metal stampings)

(Product - printed circuit boards) He says they are jobbers and make a specialized product to their customer's specifications, and this requires a great deal of personal customer contact. He feels that it is very difficult to service a customer more than one-hundred twenty-five miles away.

They have tried but have found the following to be barriers: language, export procedures, increased transportation costs due to heavy per unit weight. He has a locense to manufacture German clutches and tried to get the German company to distribute his product (ratchet arms) in Germany but was unsuccessful.

This type of business (metal stampings) does not lend itself to exporting except where you have an American customer who has money invested in expensive dies and wants to ship small quantities to overseas subsidiaries. 
They do not seek export business, but once in a while they get an unsolicited order sent to them. The source may be the foreign subsidiary of an American customer or it may be someone who has seen an ad. They advertise in a number of industrial directories and catalogs. They have no stock products. Everything is made to order (gears and racks).

Their business (metal stampings - nuts and bolts) doesn't lend itself to exporting. Their main business is in New England with some in New York. Freight is a big component of their costs.

There are so many competitors (screw machine products) all over the world, so it does not pay to look for export business.

All of their customers are domestic customers. Most of their business is in New York, New Jersey, and New England. Sometimes a domestic customer directs them to ship an order overseas, but they are still doing business with a domestic company. The product (metal stampings) is heavy and the value is low which makes it non-competitve when it is shipped any distance from the plant. This applies to shipments in the United States as well as overseas. They are adding hand drills to their product line and will consider exporting this product. 


\section{APPENDIX G}




\section{COMMITTED EXPORTERS}

\section{BEALITS}

The ease of getting into it. The company has an exclusive product, and the market is rot big enourh to warrant a lot of competition.

Additionsl sales with attractive marsins.

Profitb are about tine same as domestic business.

Frotect the product line. vives product coveraye on a world-wide casis. "The product is well-k:own, so the cost to introduce the line overseas is relatively srall. 'the accoptance of American products worl-wide was amazins. There was verj little resistance in Europe, but prices were competitive. ruI is cuite good. Viorla-wicie reputation belped domestic business.

Opportunity to get increnental sales increases at relatively little cost.

Machinery is used world-wide and is especially adapted for use in developing countries.

One of the few ways the company can grow with its present product line.

Just starting - no real feel ior it.

Extra sales. Liversification.

cood business

Profitability. Preempt markets and help maintain dominance in the United States.

An extension of the marketplace. Growing nations need to be serviced. (They look for the same fross profit as in their domestic busiress.)

The market is attractive especially in West Germany and Italy. Computer fraphics is a new concept, and the company has a competitive edge.

Increased sales and incremental profits they wouldn't have had otherwise. ('They designed one product especially for the European market.) The dollar devaluation selped them to increase their market share.

Increased business

It is interesting. The company is able to develop new markets and increase crofits, and the competition is less.

Haking profits. There are no price controls on exports.

Their customers are often ready to move faster in the United States, but otherwise their market (electronic computing terminals does not differ aarkedly from that in the United States.

The profits are generally better than domestic profits even though they ship the same product that they do dowestically.

Expended market. Eiport sales forced a metric conversion. Prolits tend to be a little lower.

Extending tro seasons. Profits are as good or better than domestic profits

\section{ROBLENS}

Credit. Company sells direct and also timough agents on a commiseion basis.

Expensive tront enci investment. Travel and pacerwork.

Geography ior servicing. Cost of servicing. Language barriers.

Sed tape. iicre documertation required. Exchange problems. ivoticeauly sore costly. Paperwork more complicated. Language proolecs in both written and spoken word. Problers of export-10yort vary from country to country. Crating and the protectior. o: the product from rust and damage.

i:elatively troucle free.

"inancing and crecit.

Language. Eaci o: federal financial assistance. Can't compte witn iermany, France, England, and Italy financial package wise. Ine Export-Import Danis is not as relpful as it was.

Japarese and "estern European competition and the lassachusetts tax structure.

No more proolems than any other business once you know the routine.

It is not clear that tiee returns are equal to the blood, sweat and tears required.

Lack of people on the staif to pursue the opportunities. The president has the ideas, but has difficulty instillins nis enthusiasm in his subordinates. Agency selection, (Department of Commerce nelps nere). Language.

Financing until EXI:\{4ik guarantees. Maintenance of equipment aoroad - must train rationals. Payments. Custom valuation. Foreign exchange problems.

Political upheavals in Spain and Portugal. The bankruptcy of one distributor.

Niarkups.

Xiror only. Snipping - they use containers and pack their own.

Paperwork, letters of credit. The time involved because of the distance usually slows down the process.

They have opened the eyes of potential competitors as well as potential customers through participation in trade sairs. 'the cost and strain of deaiin at a distance.

Export fapers and documentation

Orders are more costly to process.

Communications. Time involved in paperwork. 


\section{EEREFITS}

Allows an almost unreisonable amount of forein travel at company expense. :asic business reason for travellins is to discuss problems with custoners and agents. Proit is high.

Increased volume, and this has a significant effect on profits because of a righ breakeven point.

\section{Profits}

Increased sales. Exrorts say rise from ten to trenty percent of sales in $157 \%$. Canada and Brazil are growine by leaps and bounds.

Increased sales volurie and higher profits

Extra sales volume

\section{PROSLEMS}

iso problems.

Each market is different, and you have to krow and understand each one. Product differs from country to country, esvecially in Europe. irisk.

llone in particular. Overseas agents are really distributors who take title and so absorb the prodems also.

Fiper 'icr'i arci scllections. il feels that the banks takes advartase of him by using his money for thirty to sixty days. ie ieels that licensing may help this.

Paper work and shipping. Communications from a distance.

ione to speak of. His customers are usually the foreign subsidiaries of American corporations, and the American parent acts as the purchasing agent.

\section{BENEFITS}

\section{Increased sales}

Extra cales

Increased sales and profits

Corporate icage, i.e., international company. Increased volume which perits large supply purchases. Opens up producta to be imported, and this complements the product ine.

Extra calee. No one can do the precision machinin:; they can do.

High profits

Increased sales volume at a profit margin higher than domestic business.

\section{PSOBLEMS}

Paperwork and froblems in communications, 1.e., language and drawings whicr. are hard to decipher.

iuropean companies that get subsidies for export sales hurt when they meet them in the market. Faporwork.

beinc able to sell competitively against European and Canadian firms because of sales tax, duties, and wage differentials.

Locatir. viable outlets. Pricing product competitively. La:ieuage.

linne.

Orders are too small to service properly. Payrents. language problems. Packap,ing.

Whey had trouble with the export agency they used. Paperwork. Collections. Import licenses - takes $8 i x$ months in wrazil. In socie countries ticy havo to deal with government monopolies. They fecl that it really needs a special percon to handle export tusiness, and this is difficult to justify in a emall company. 
APPENDIX H

THE KOLMOGOROV-SMIRNOV ANALYSIS 


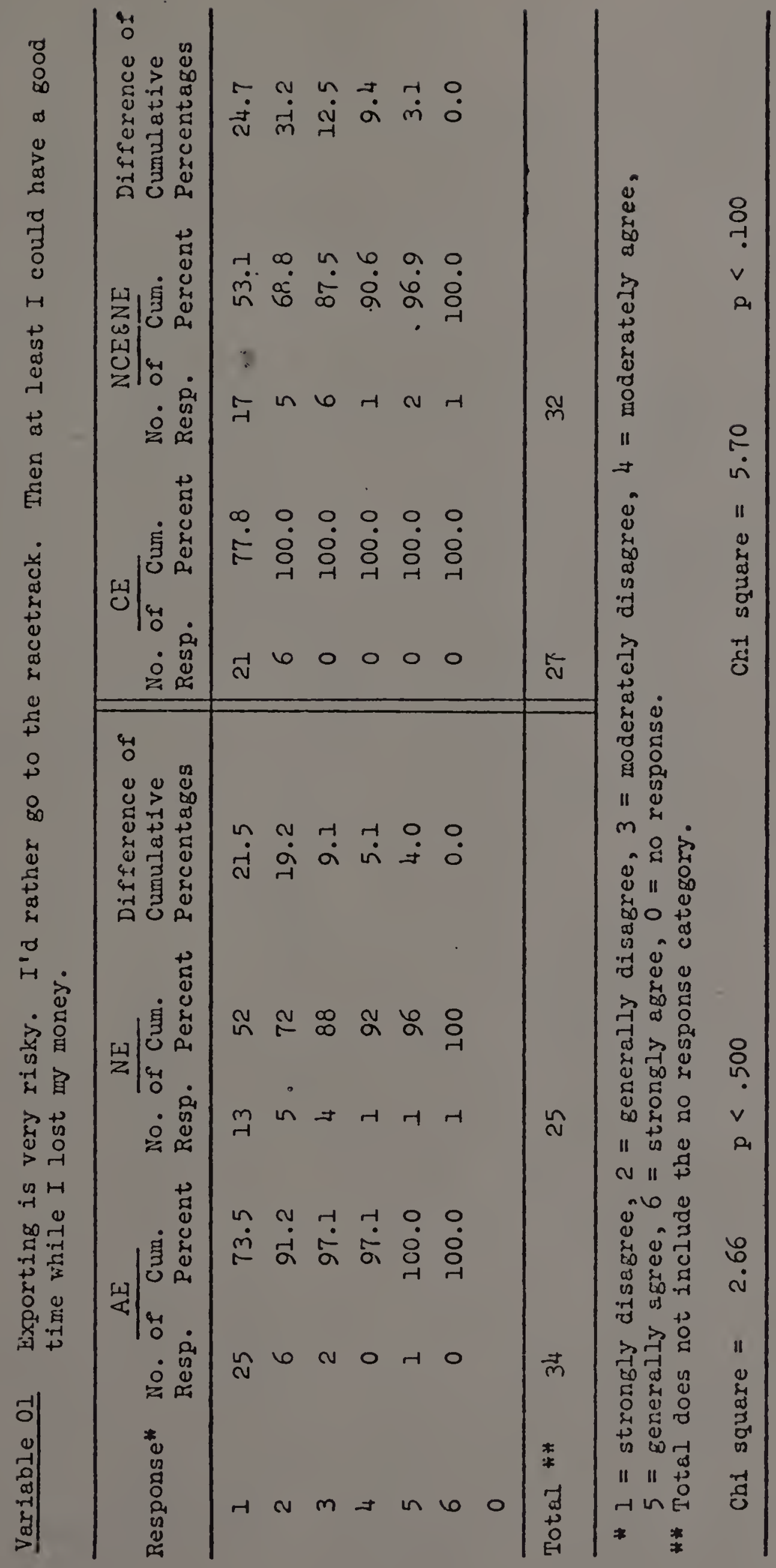




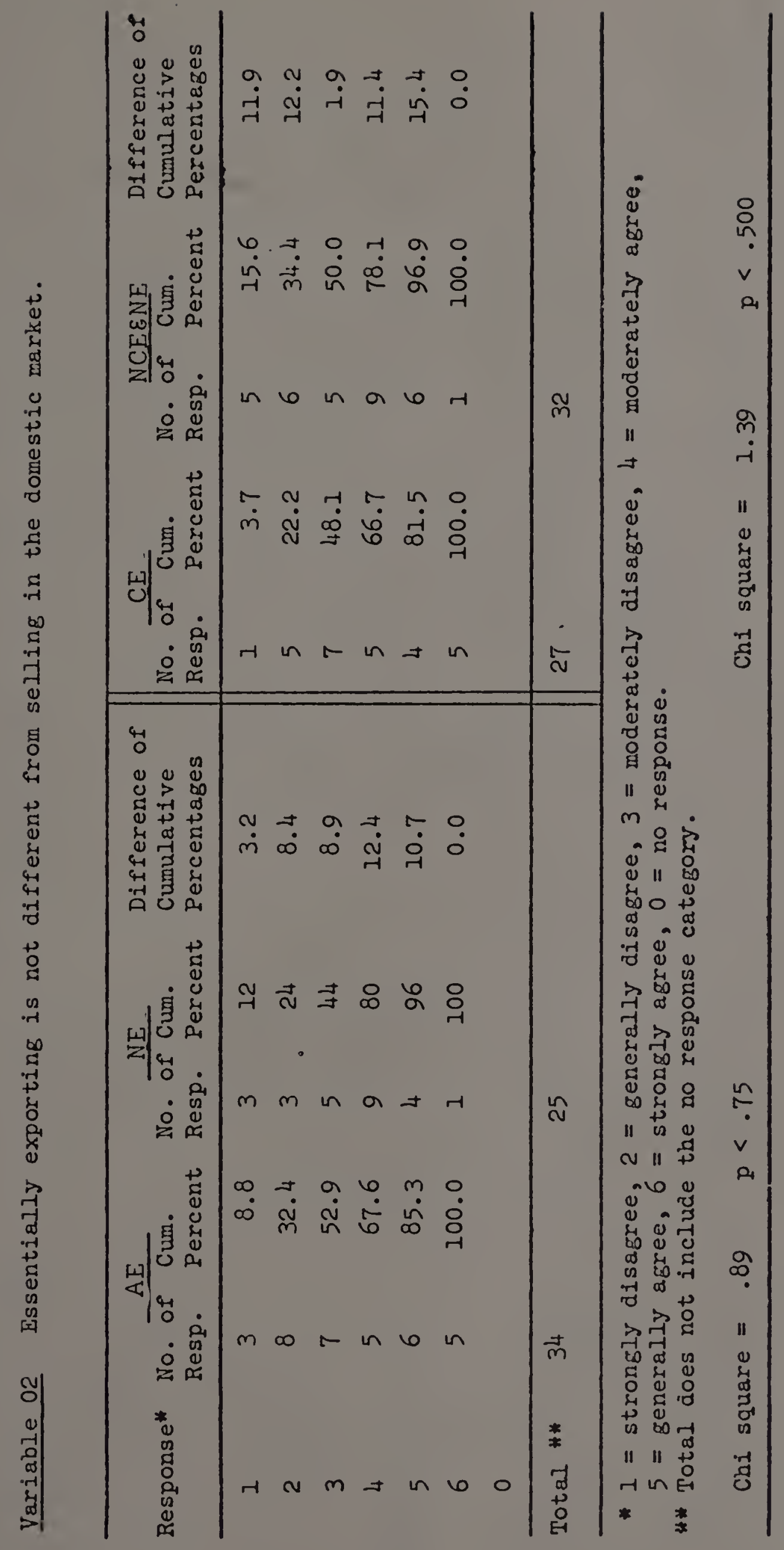




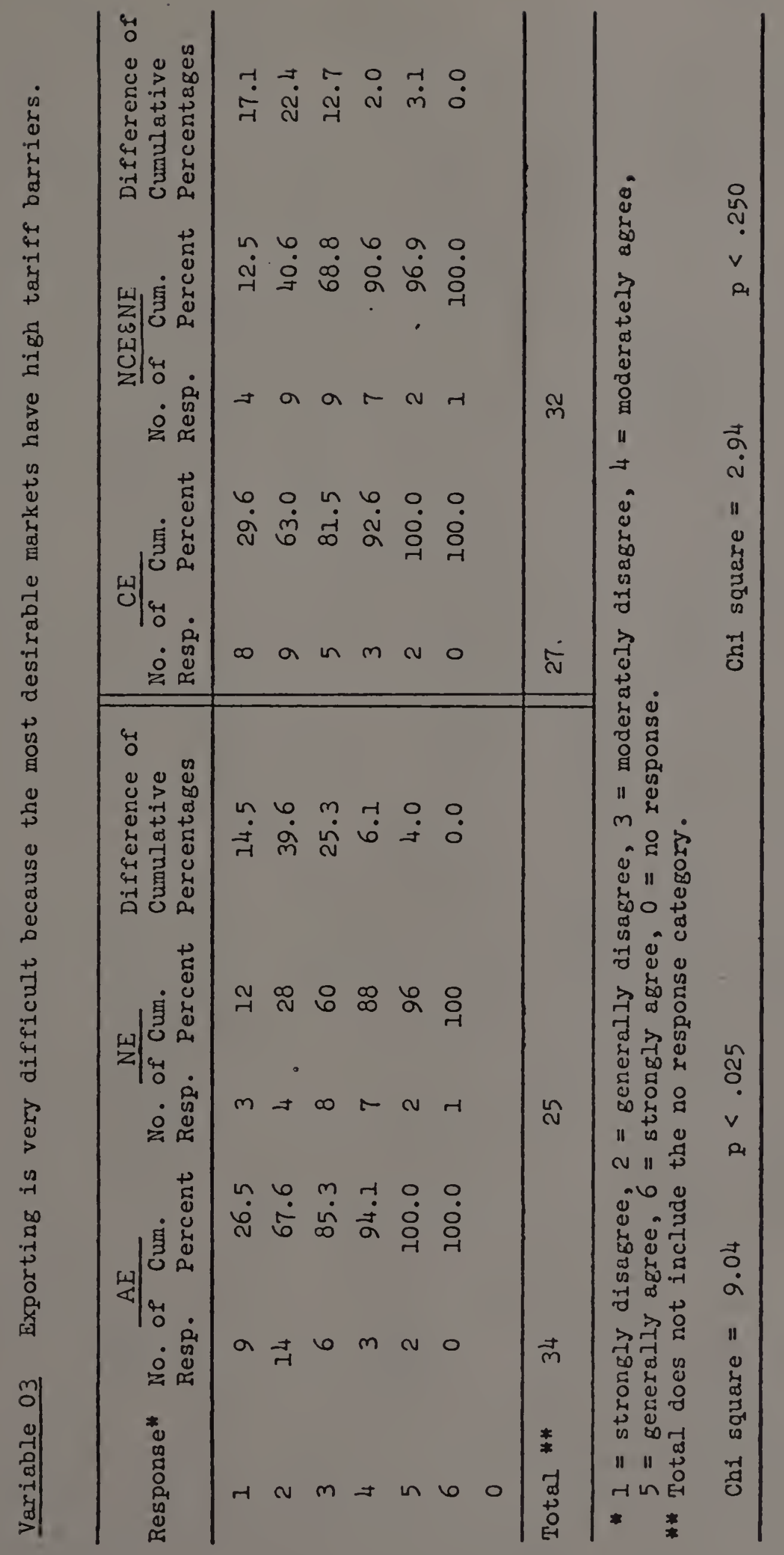




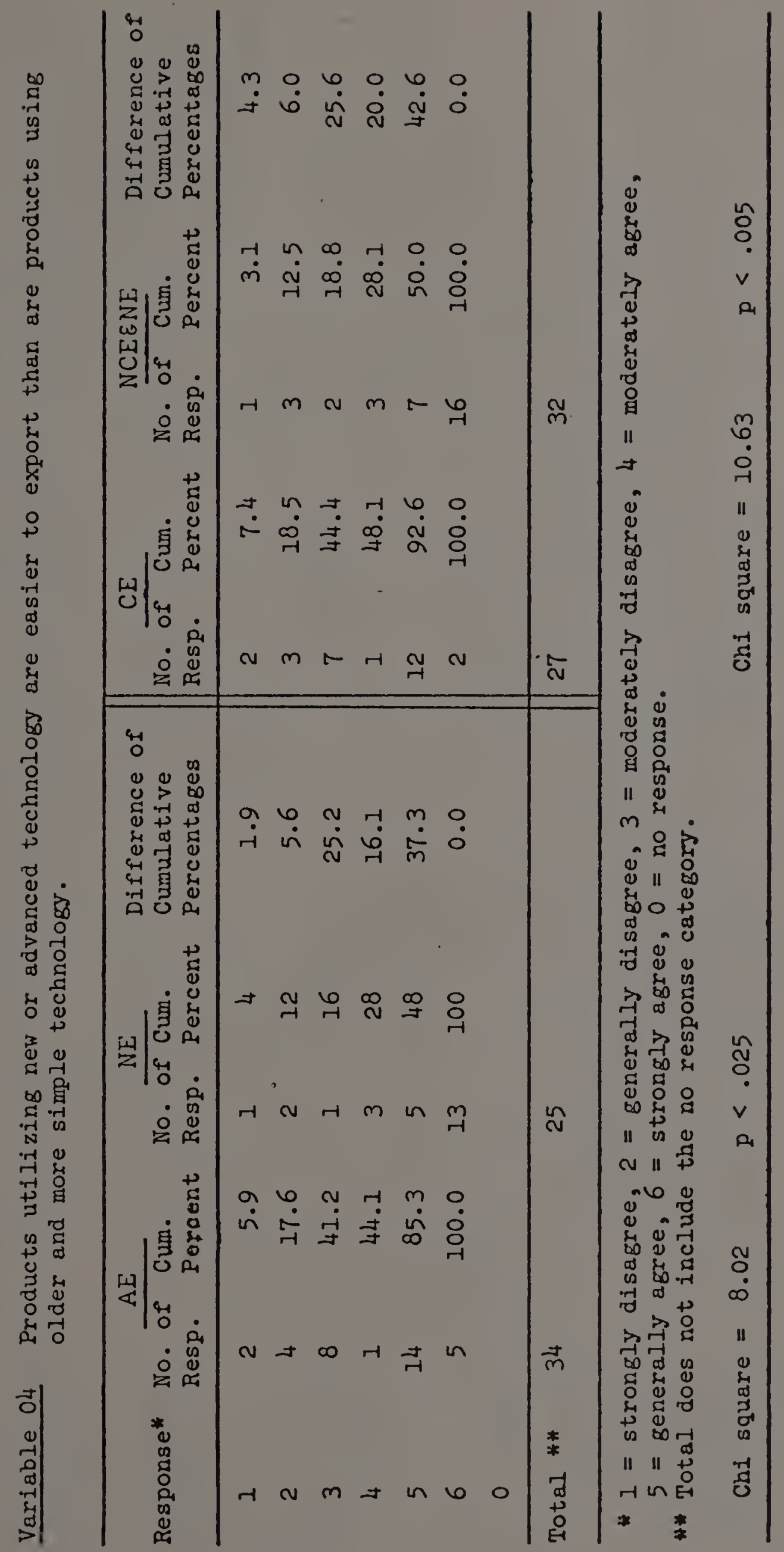




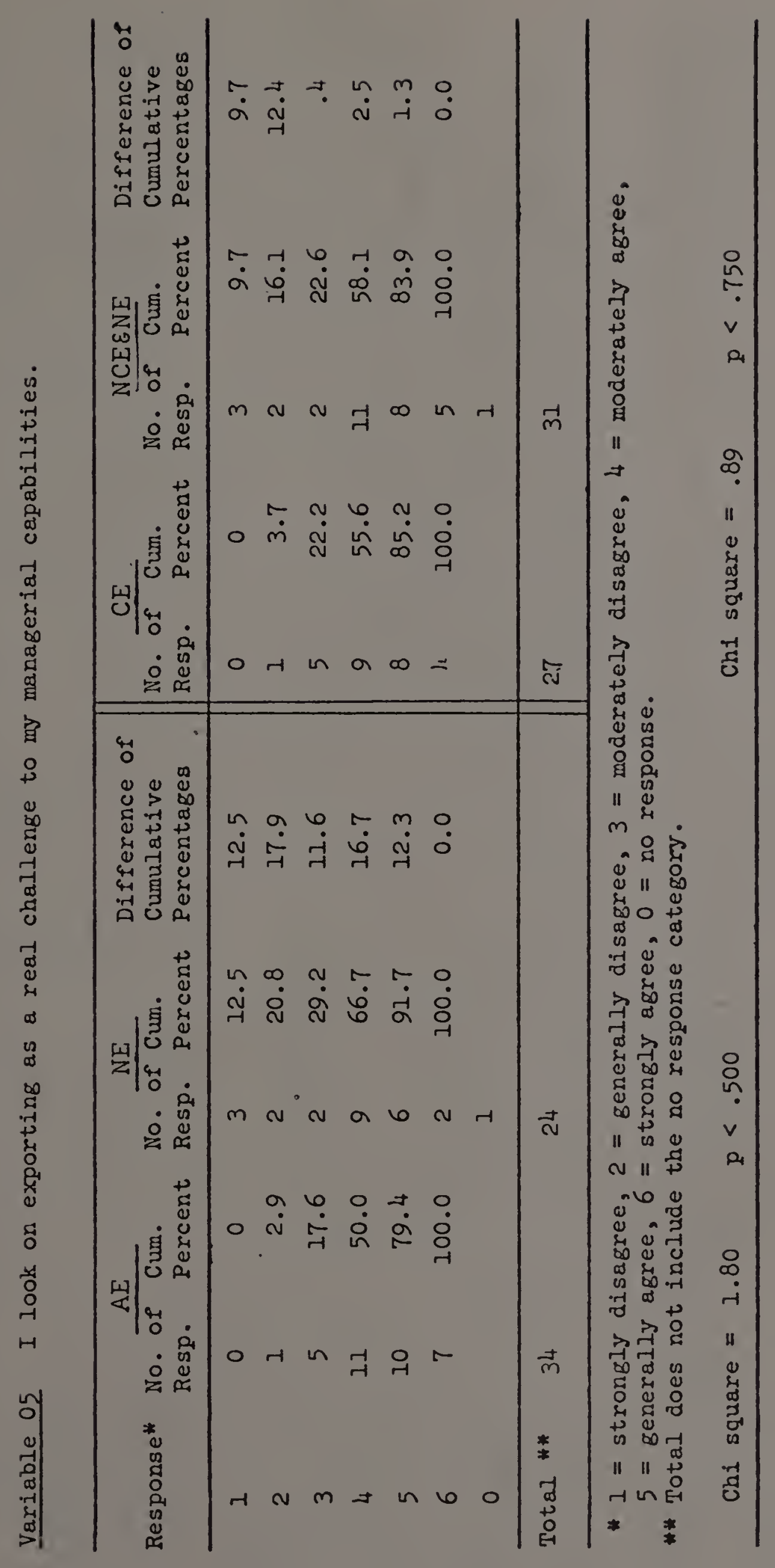




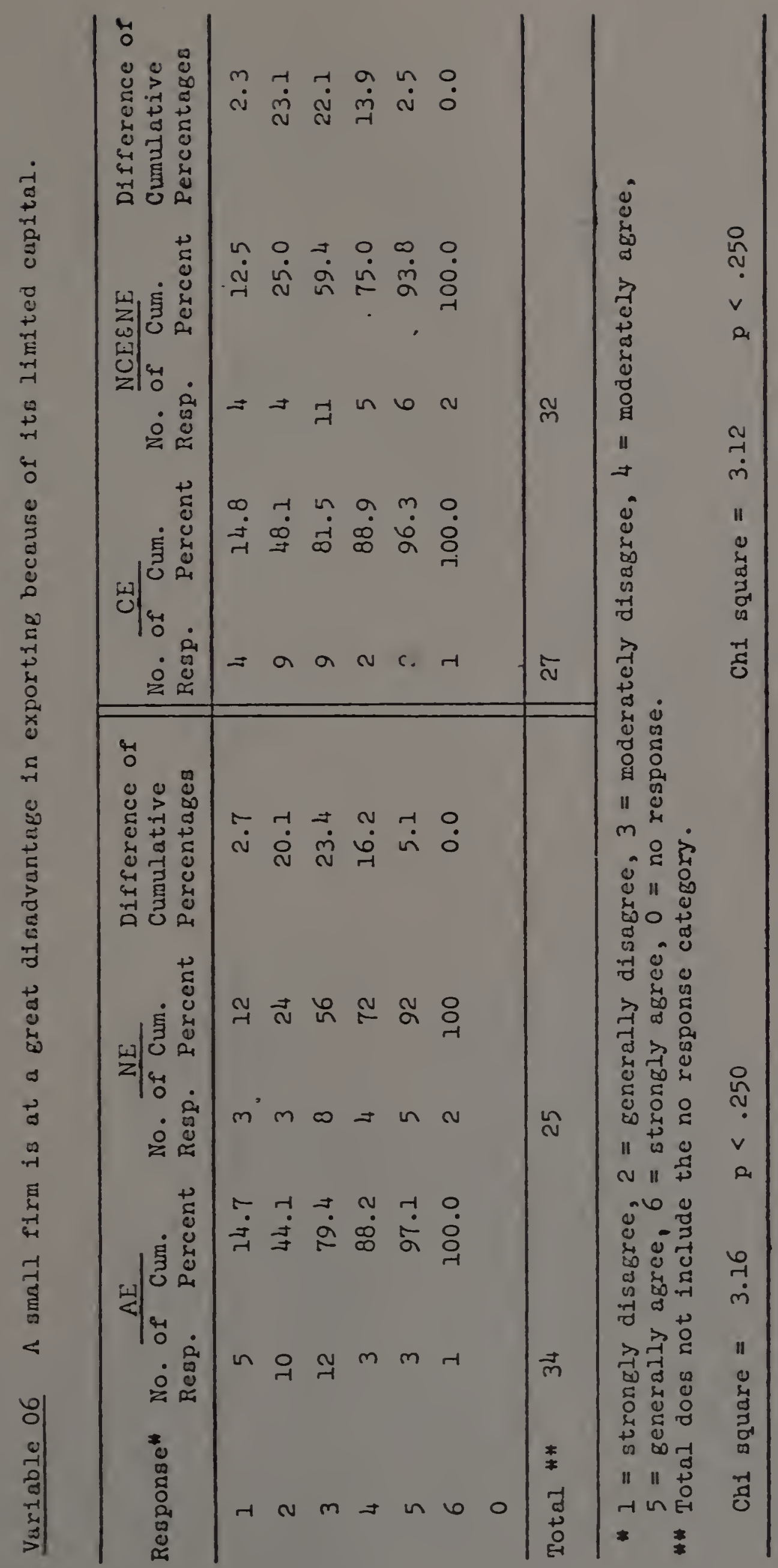




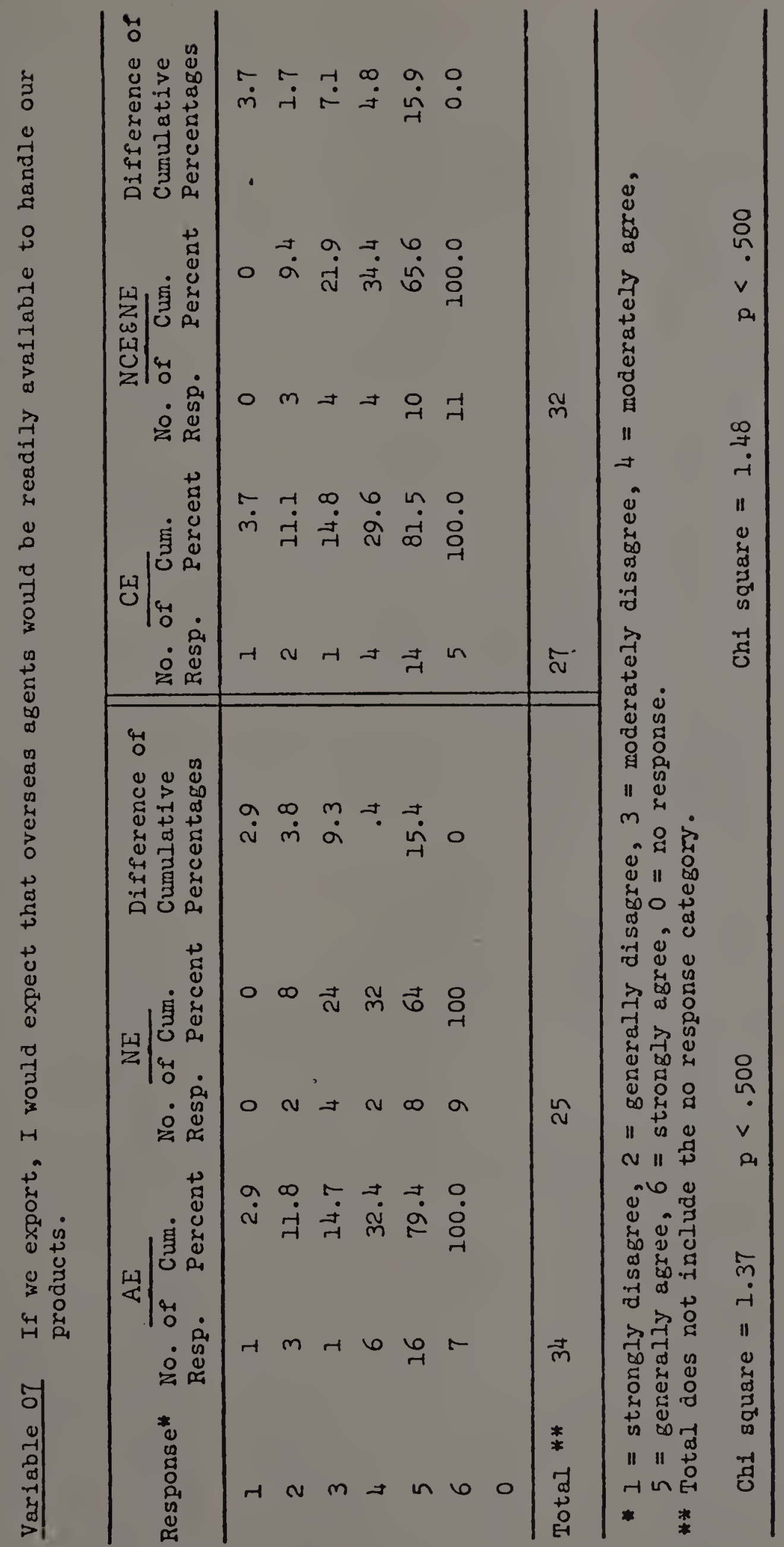




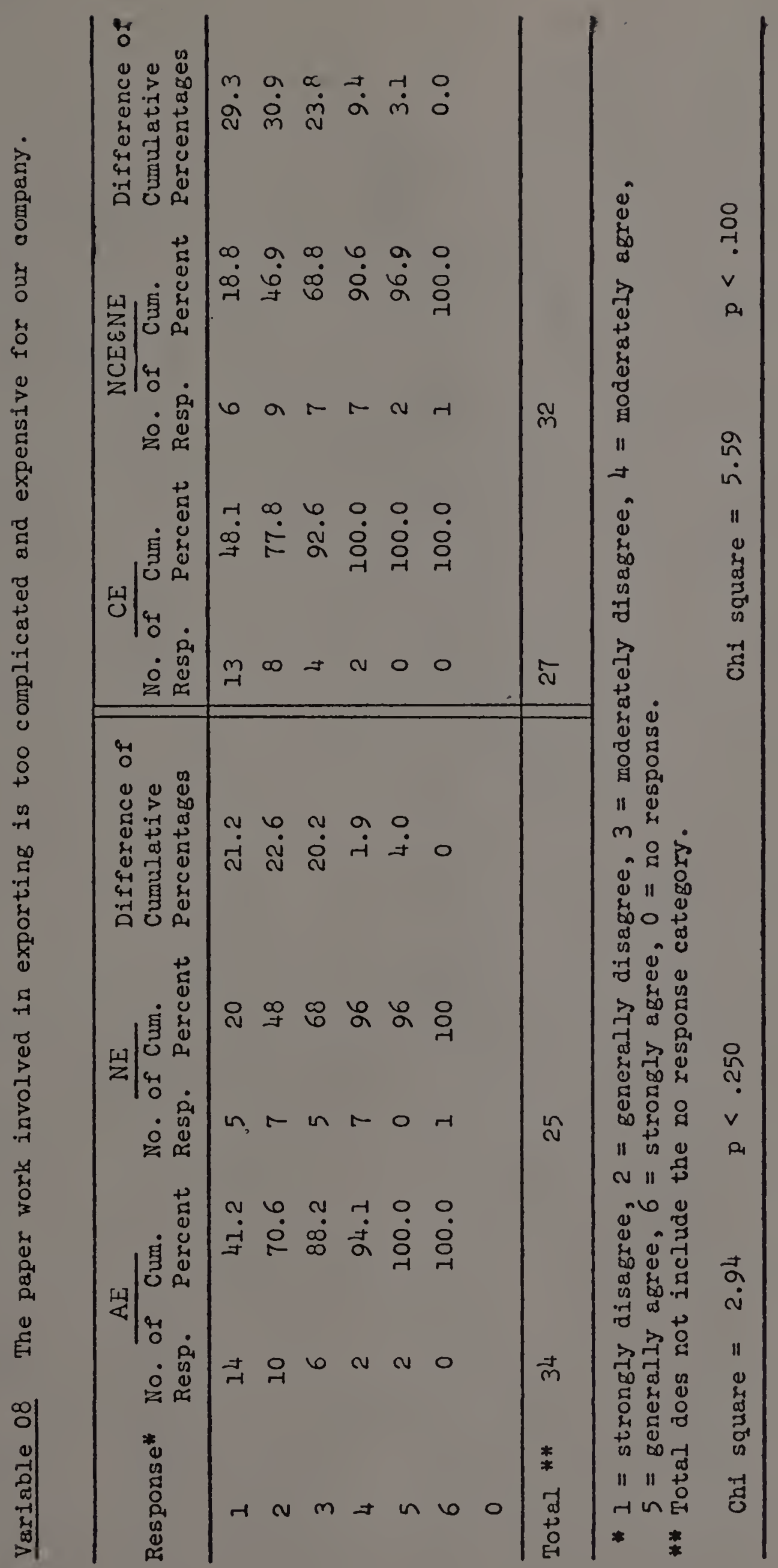




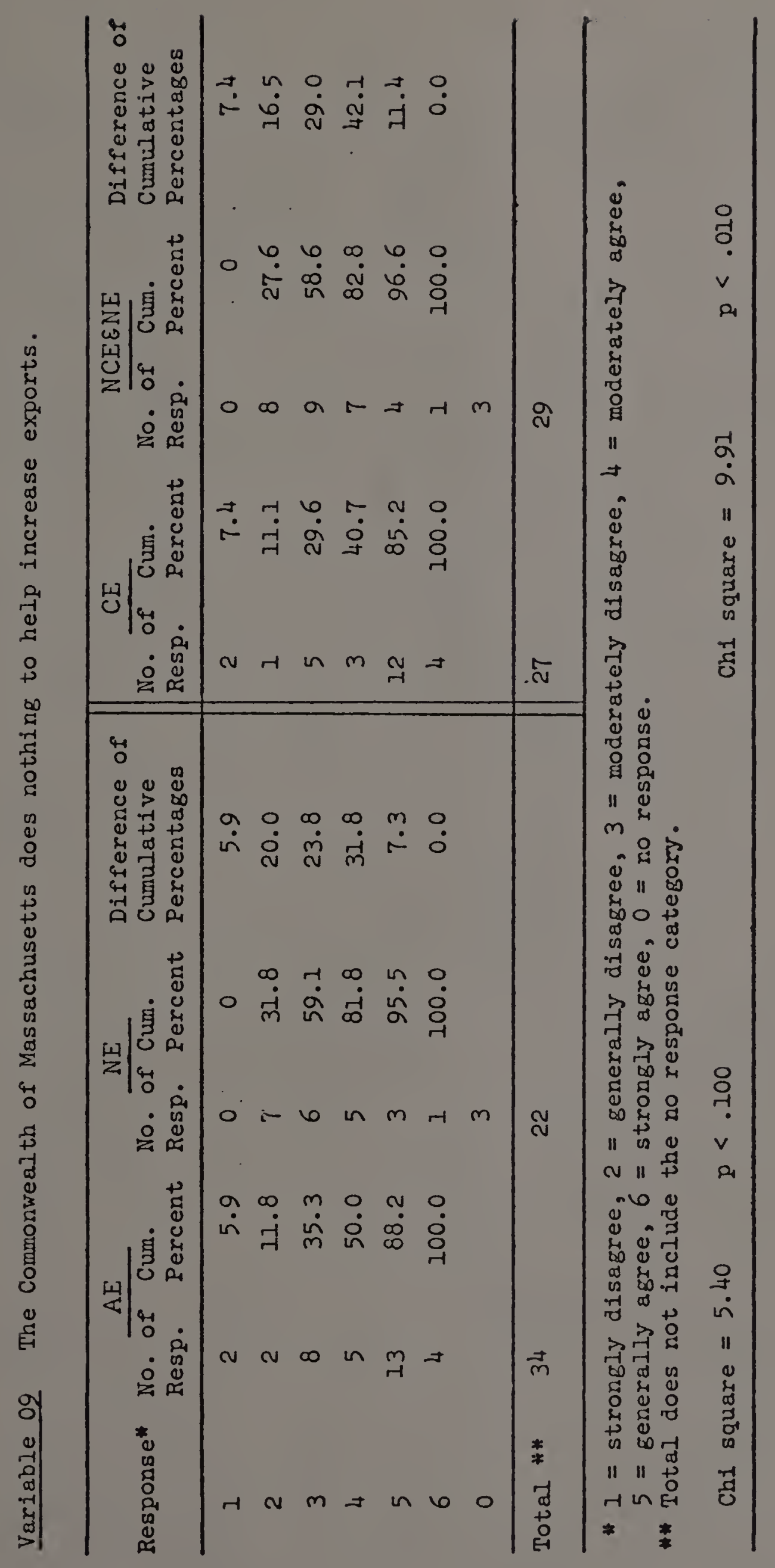




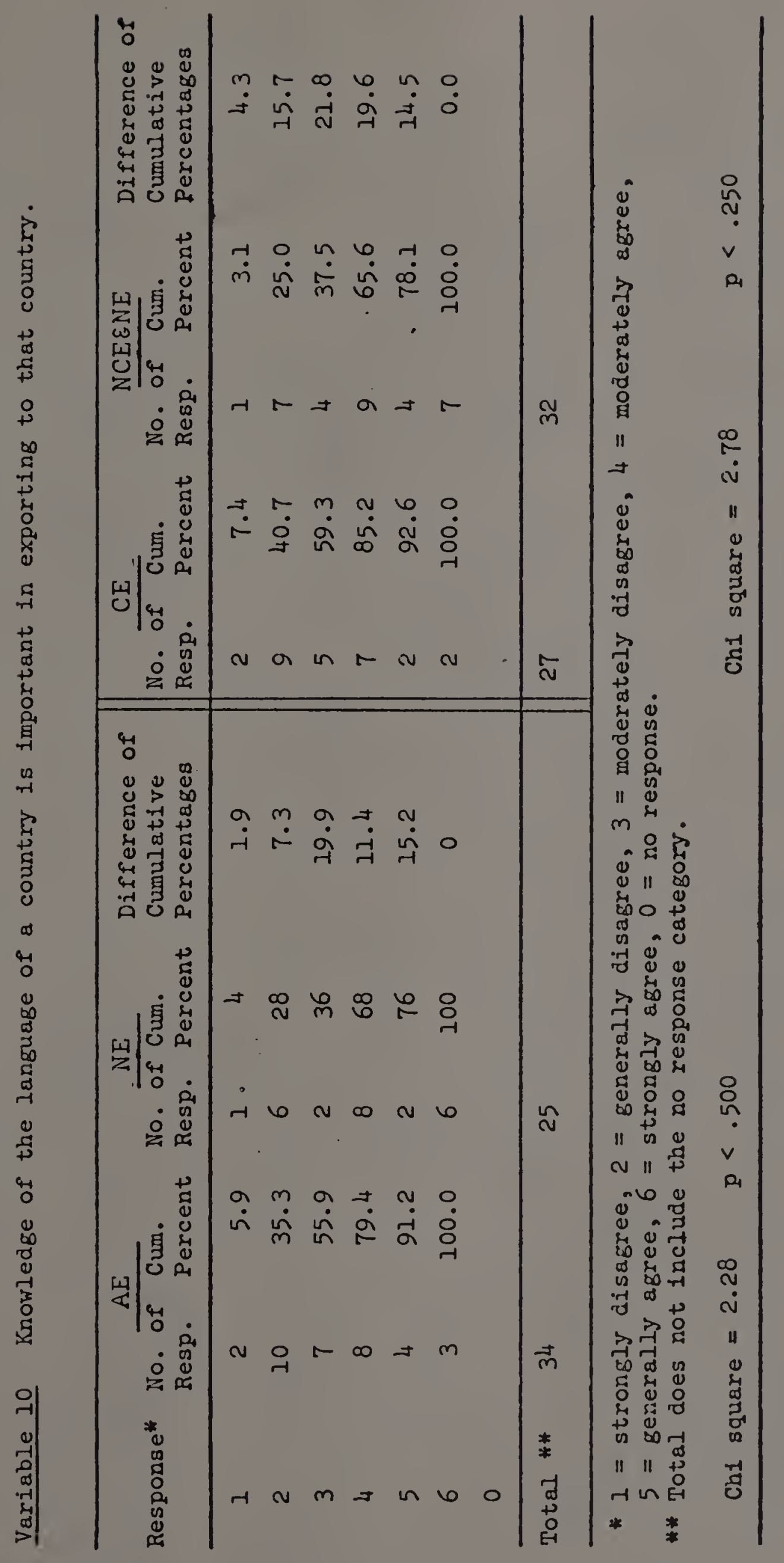




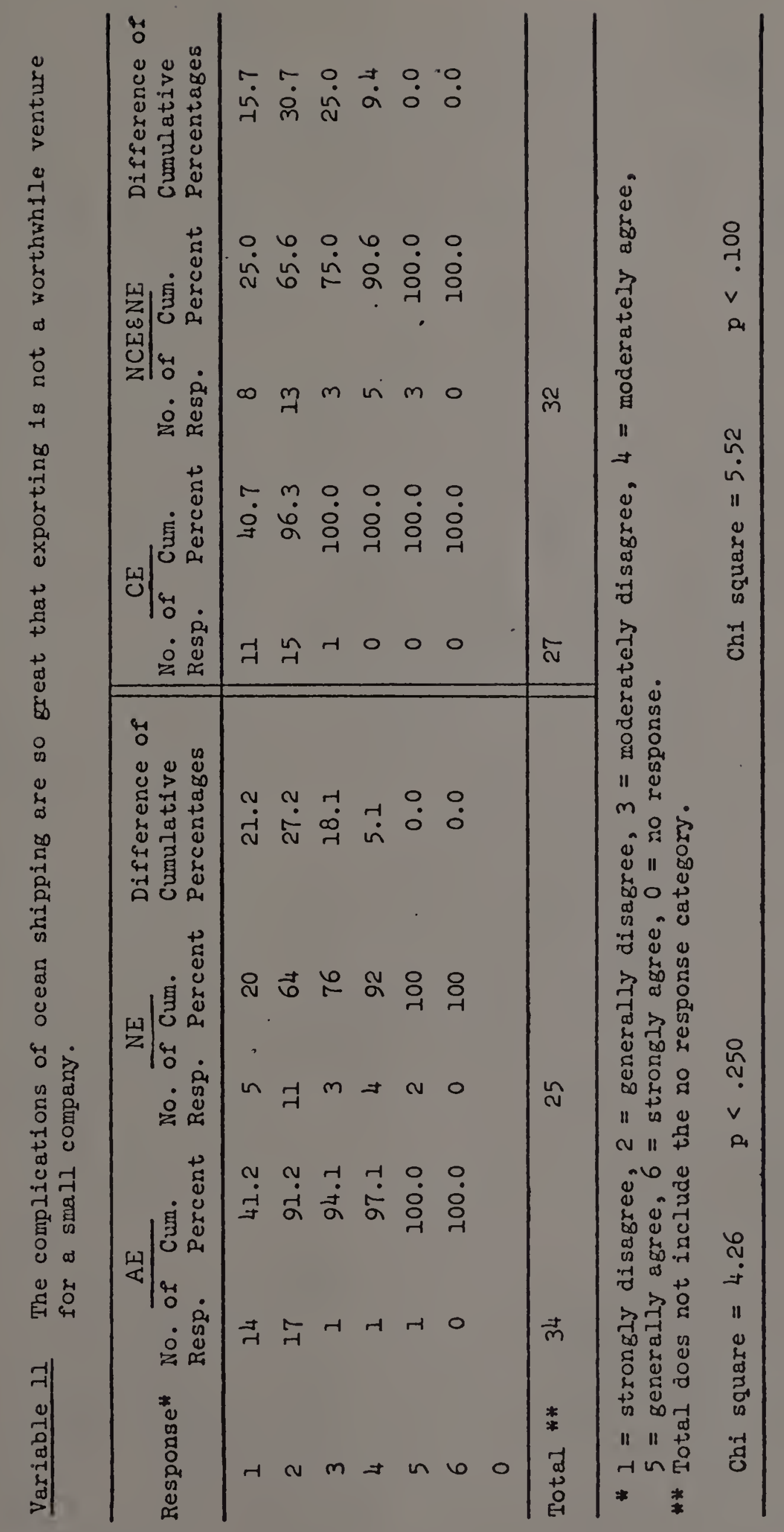




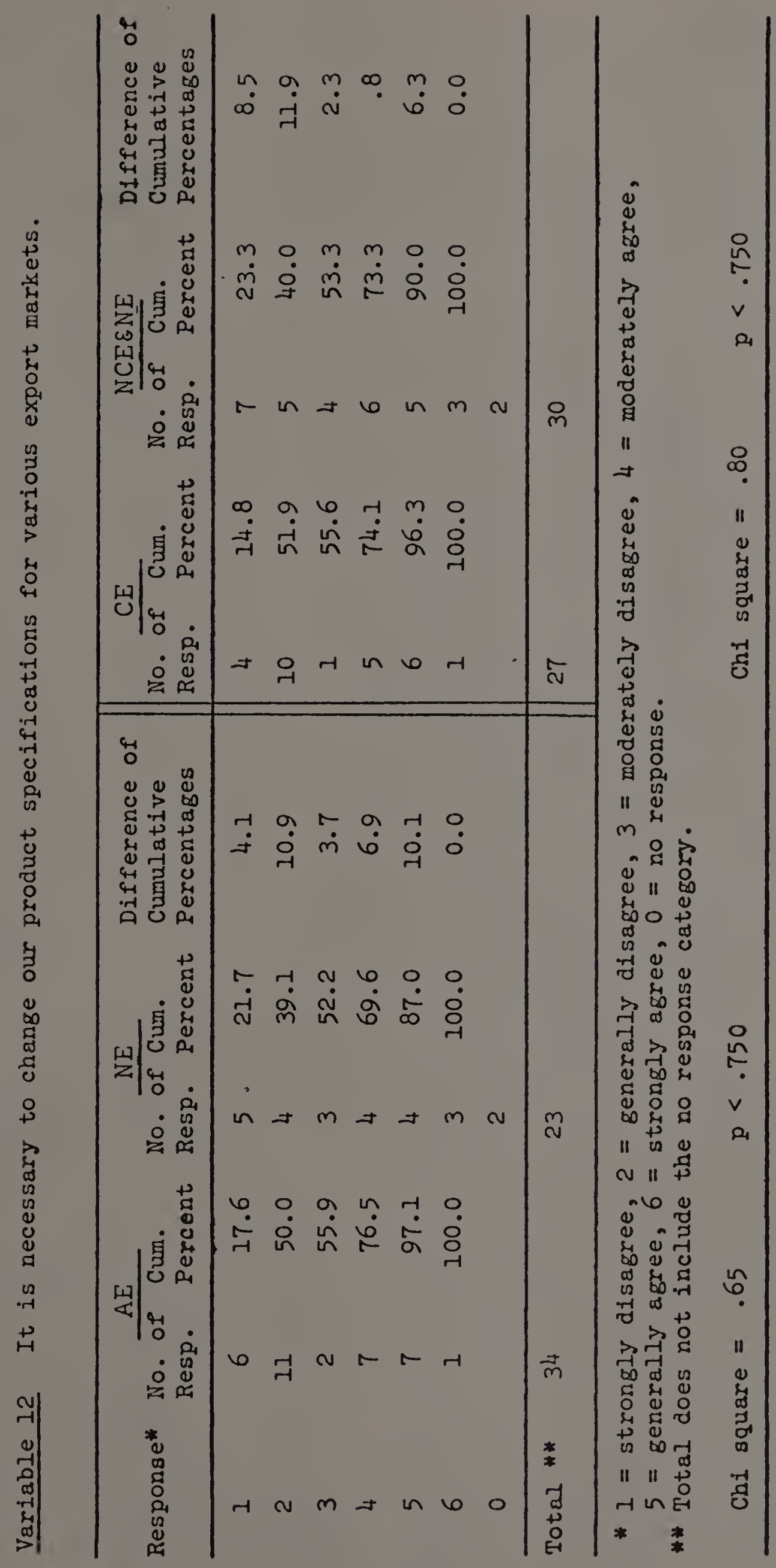




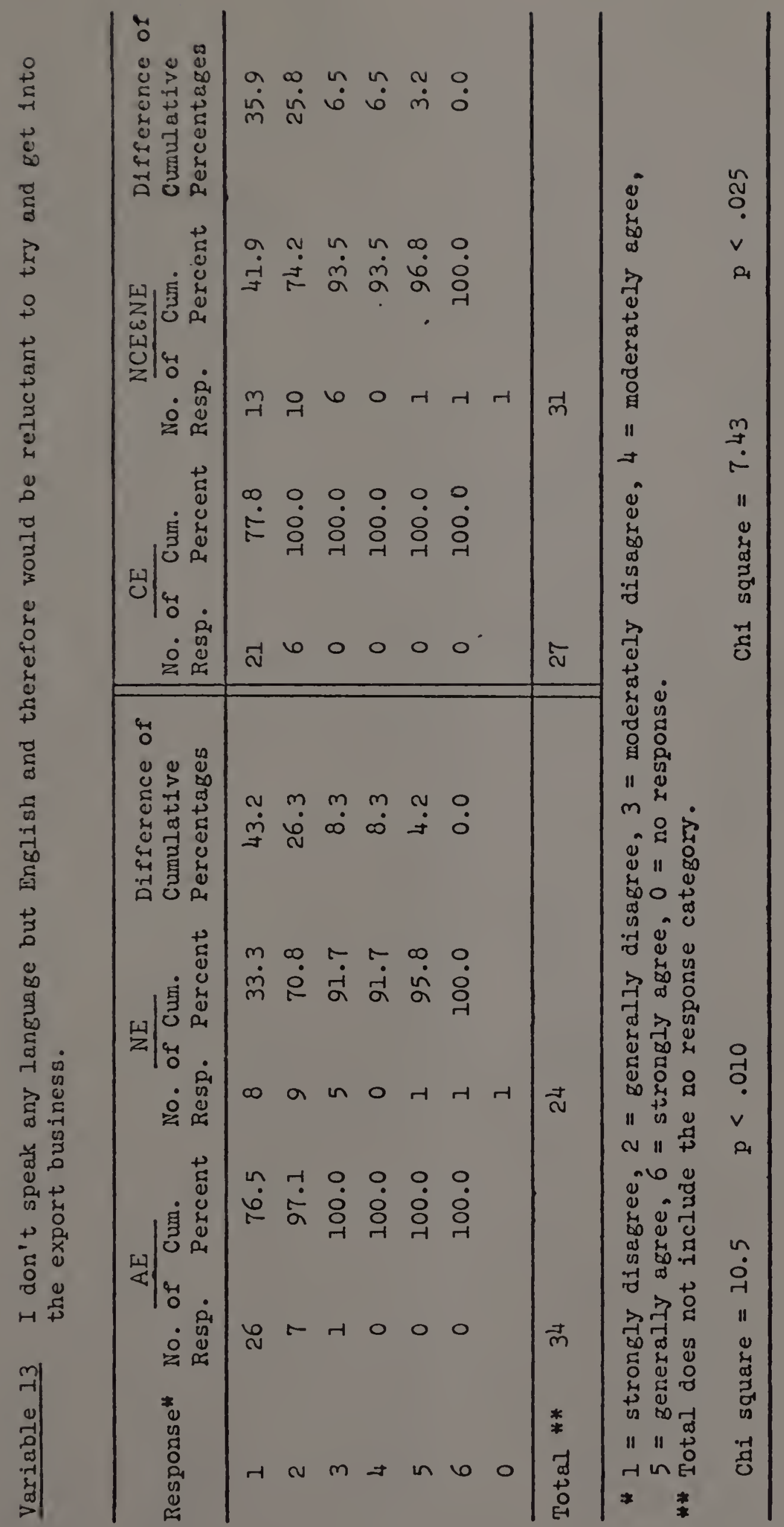




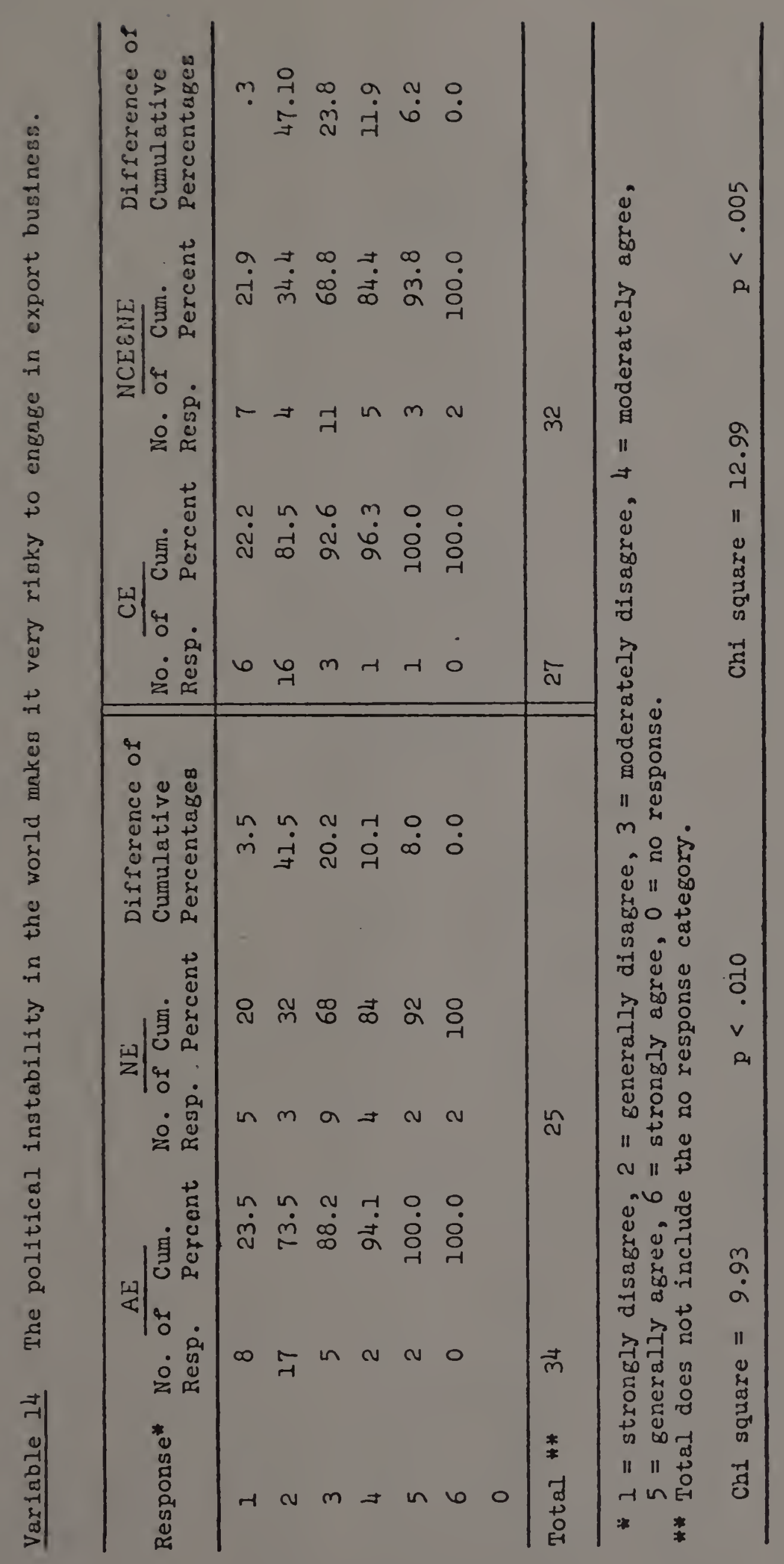




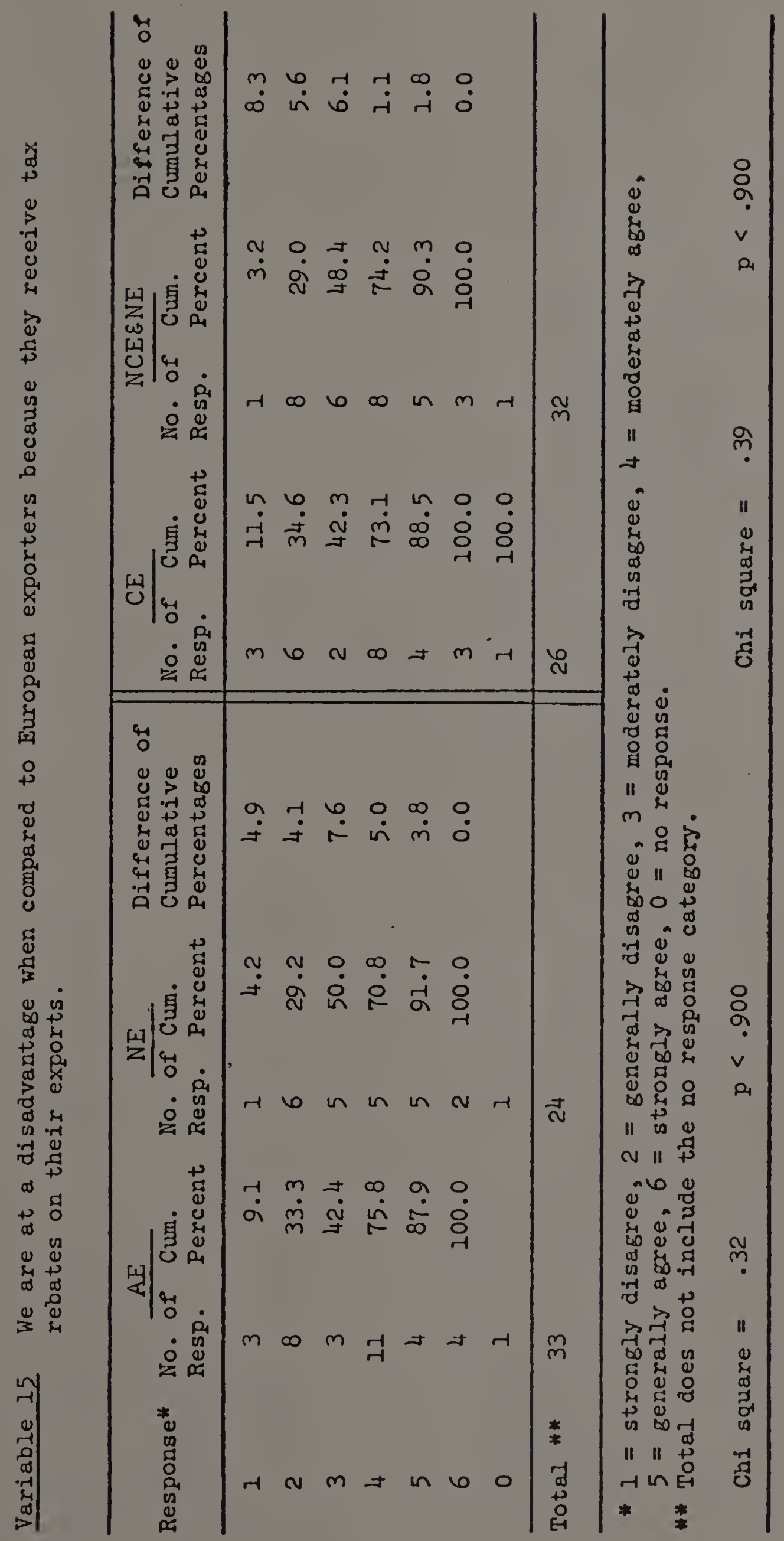




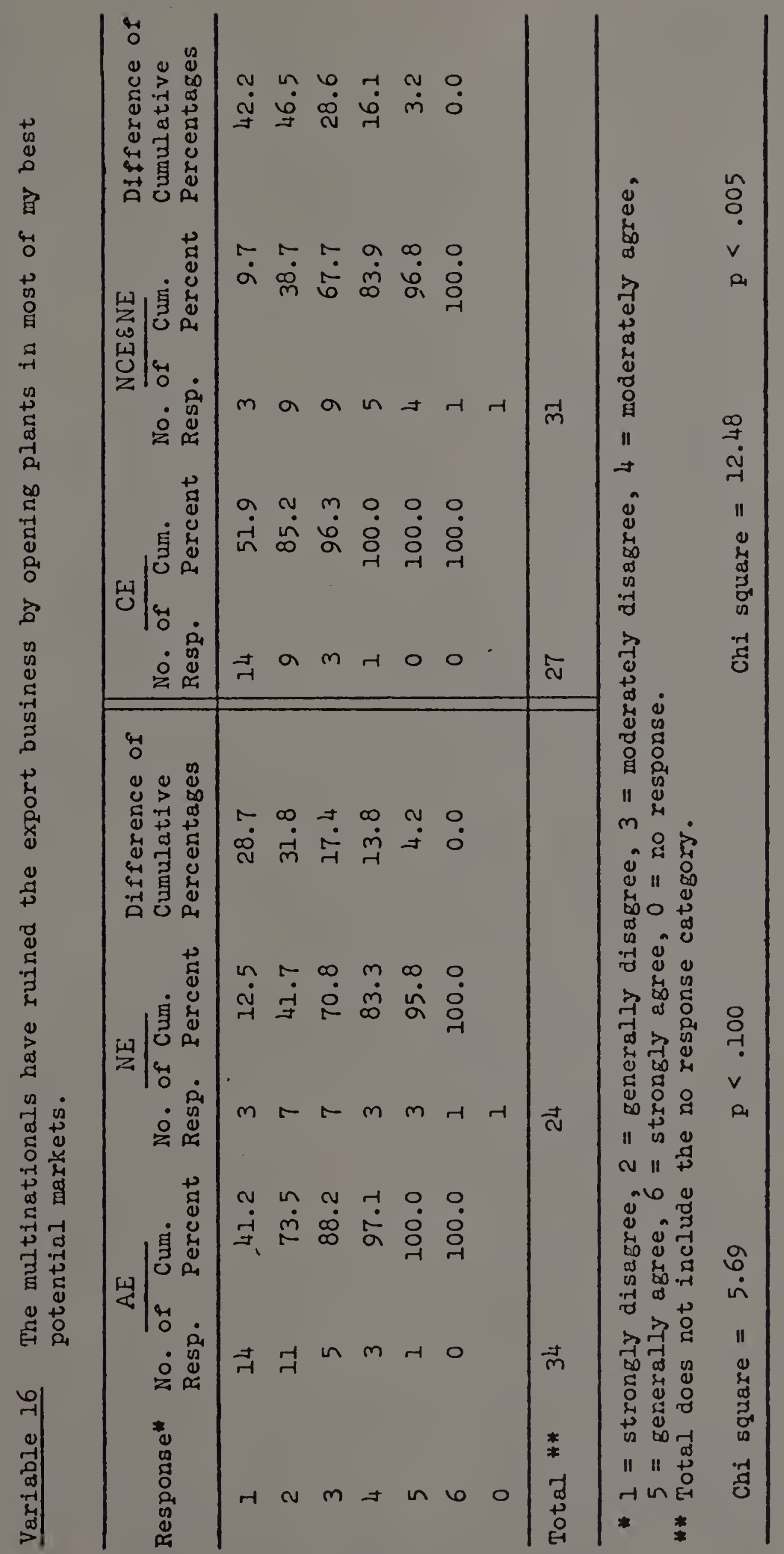




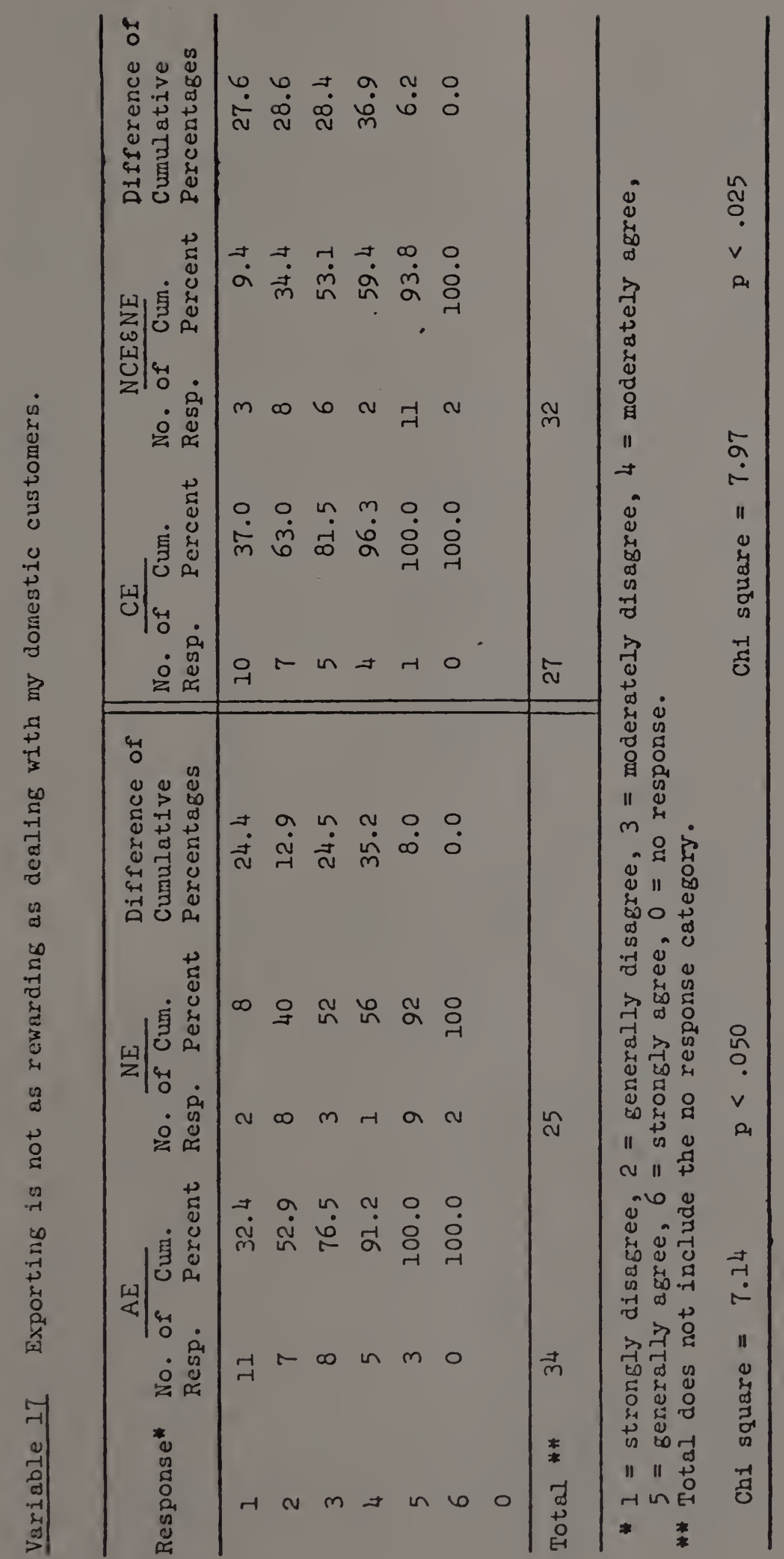




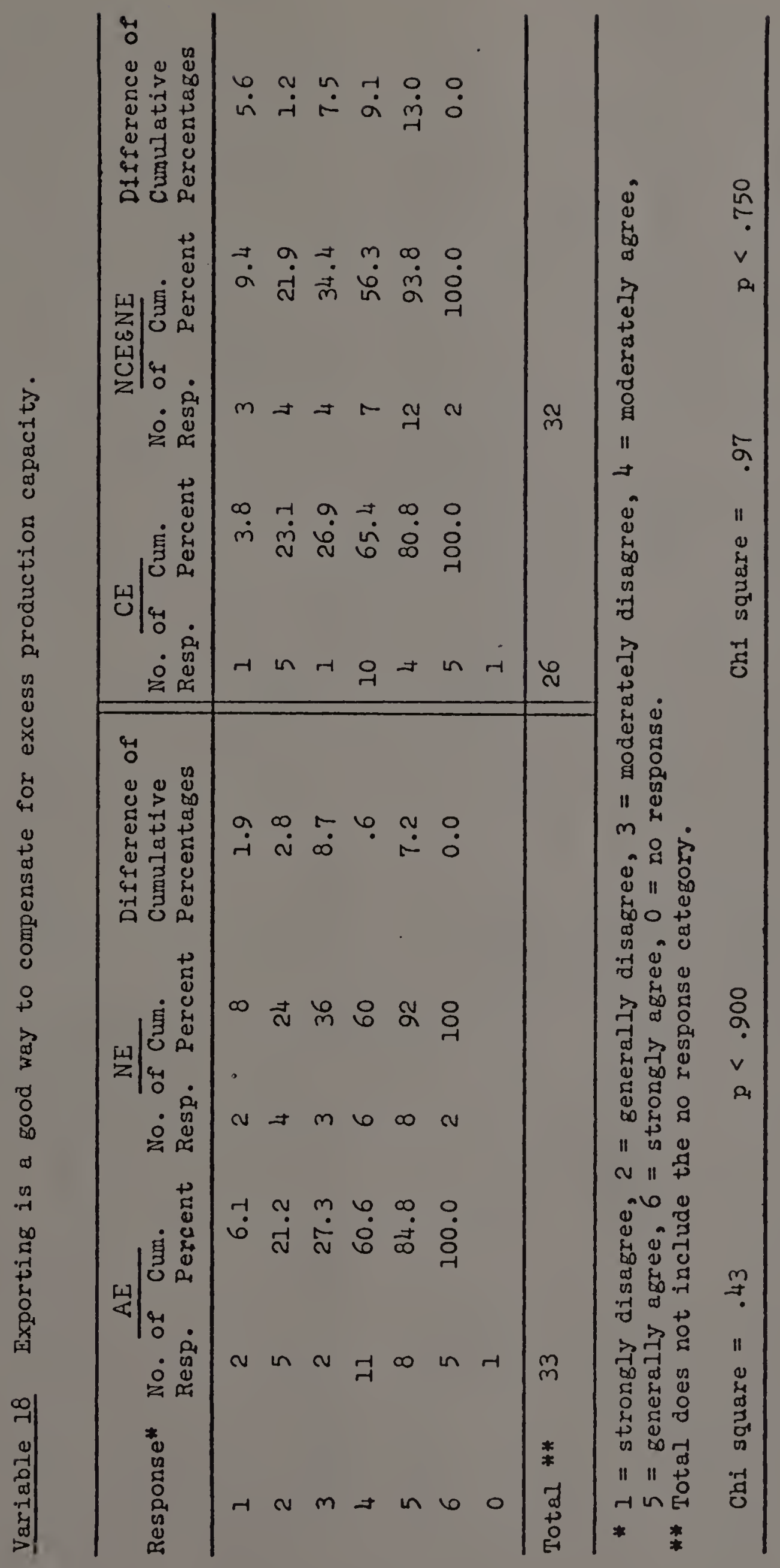




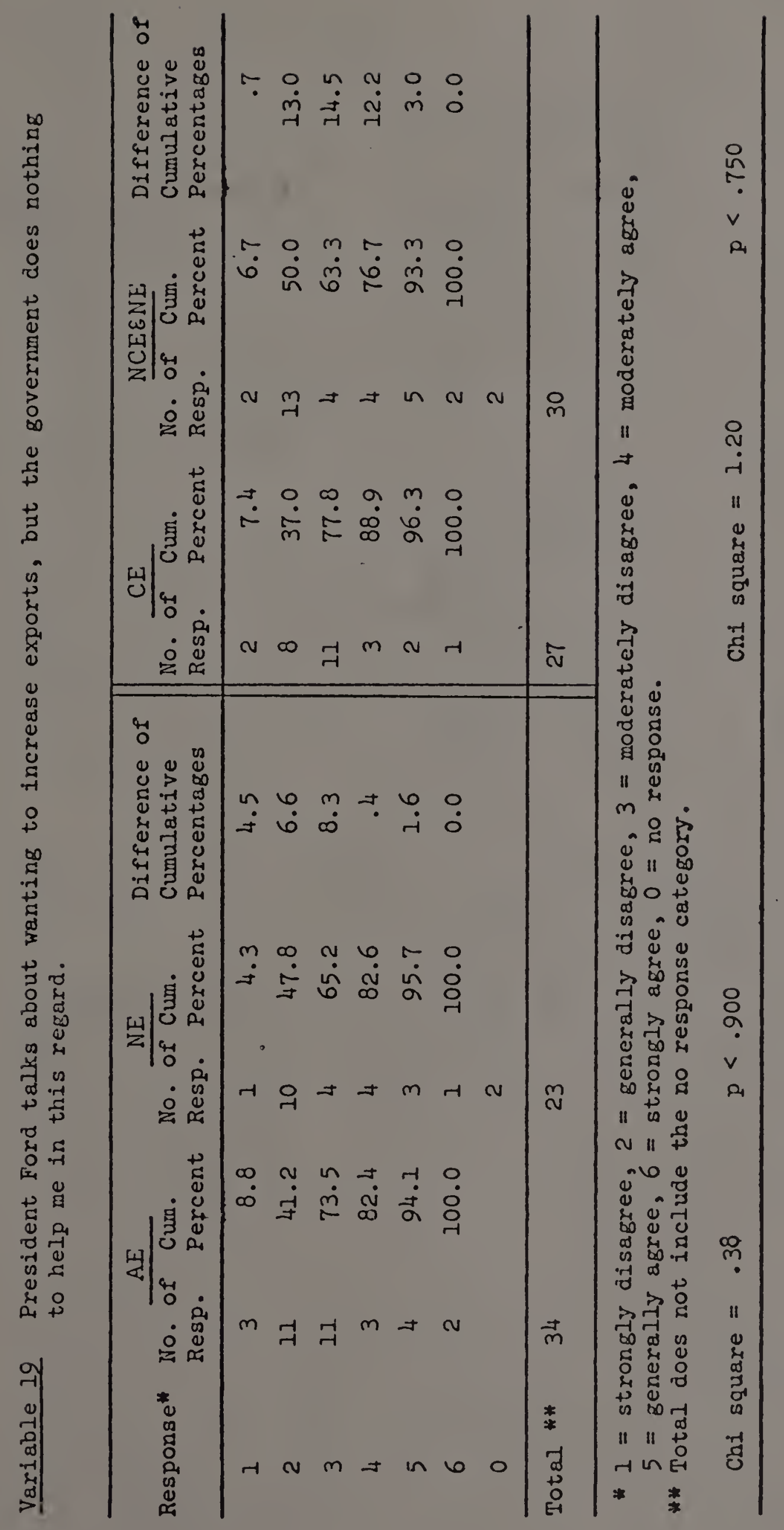




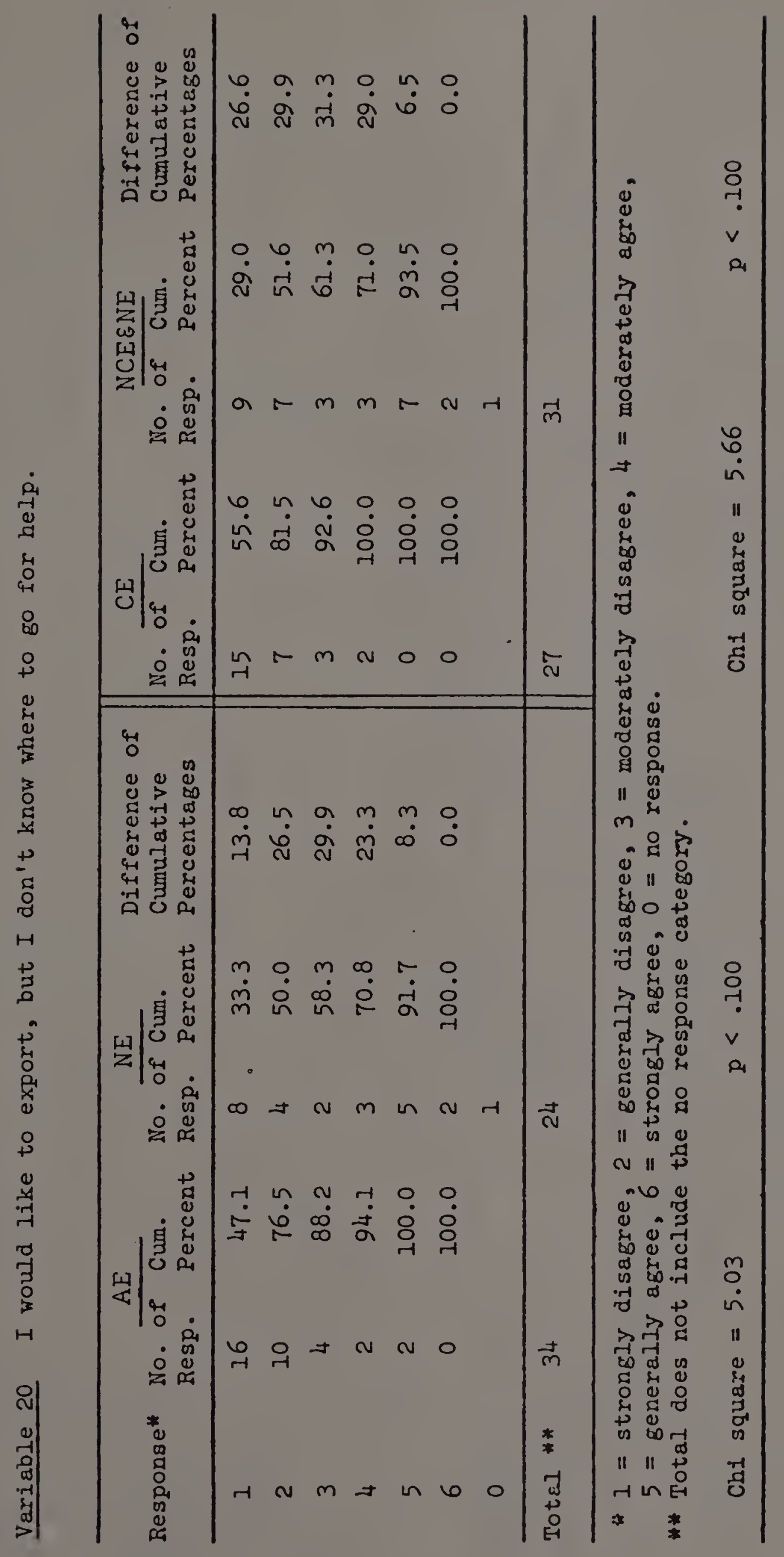




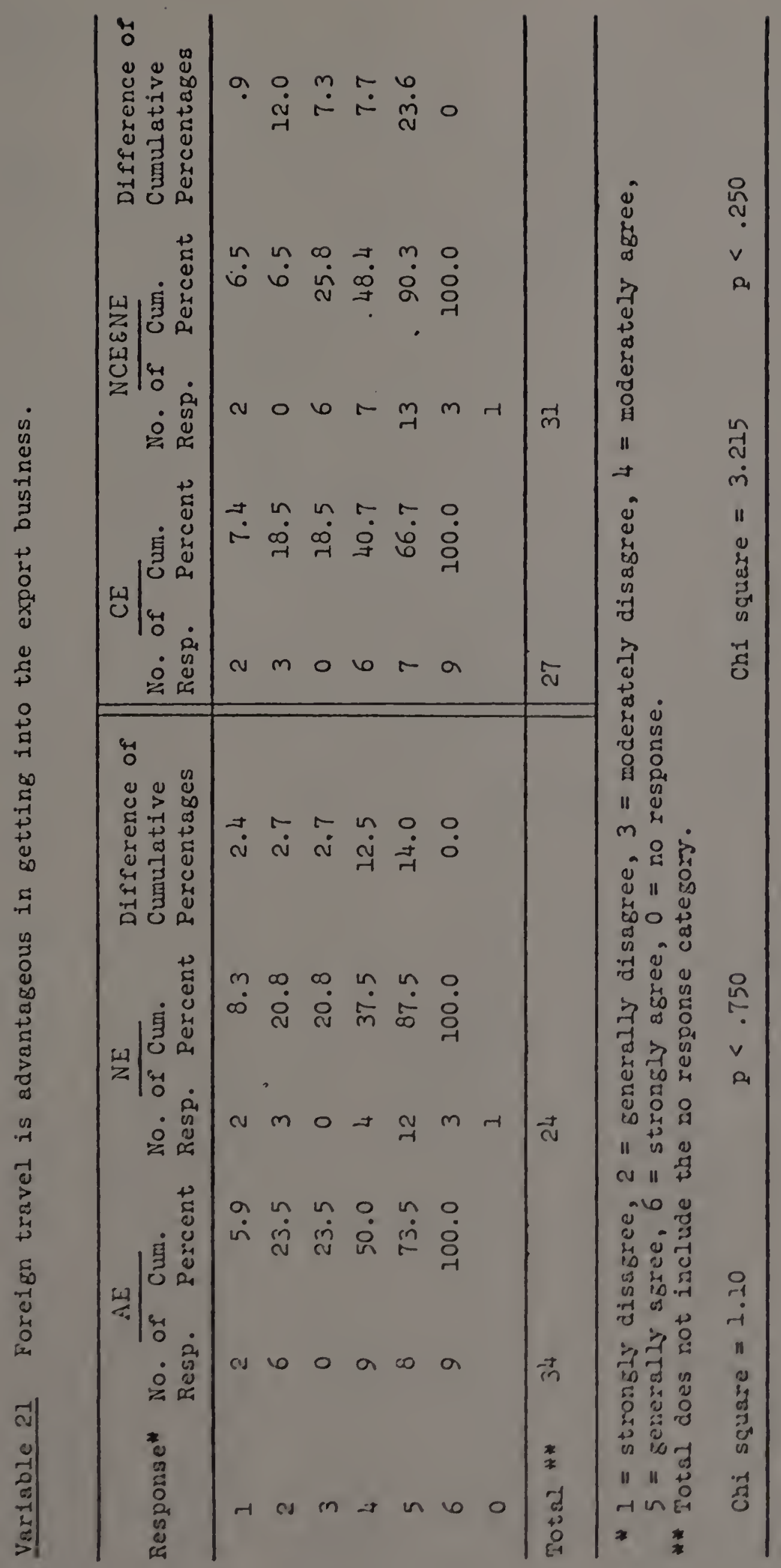




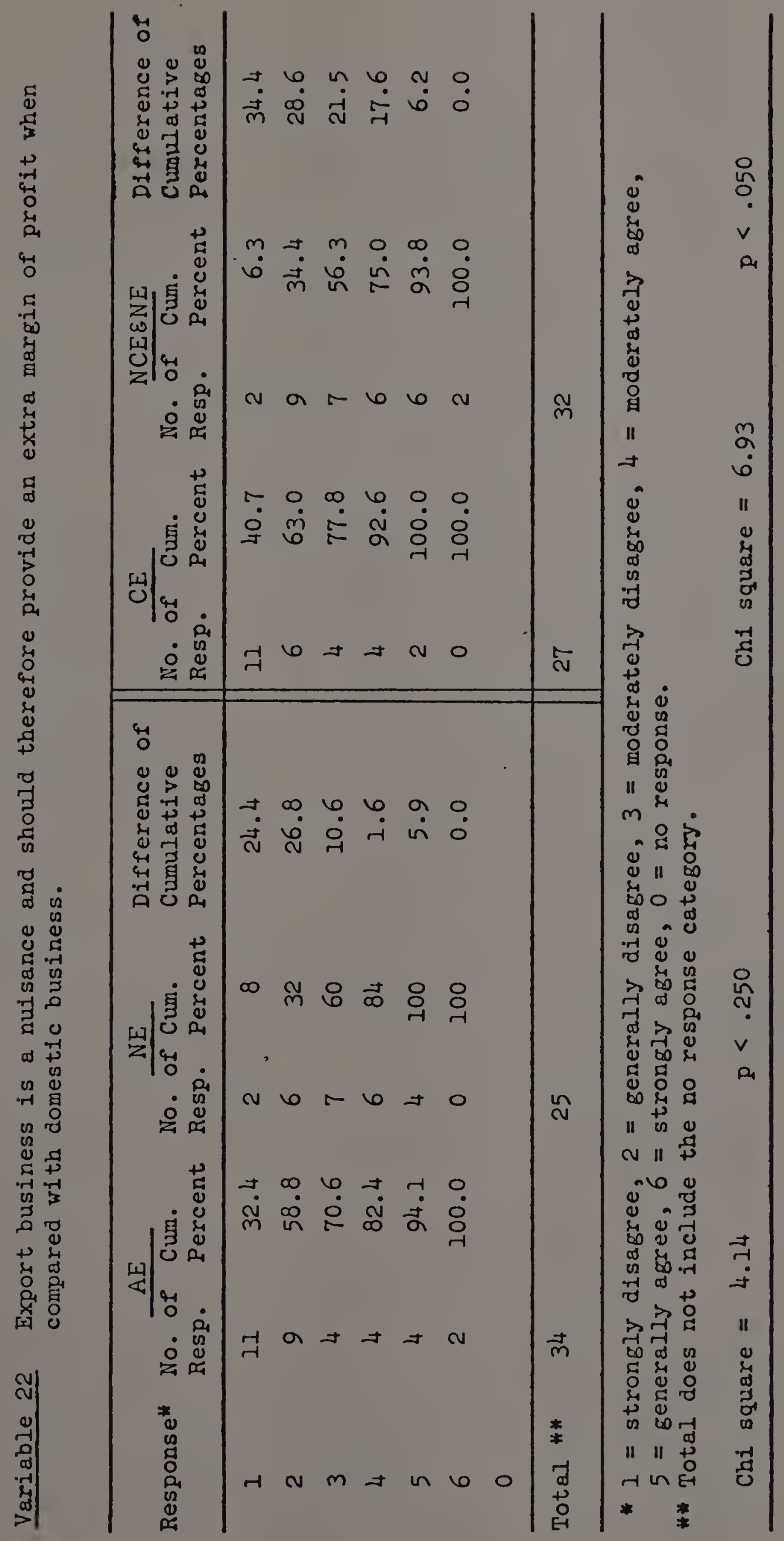




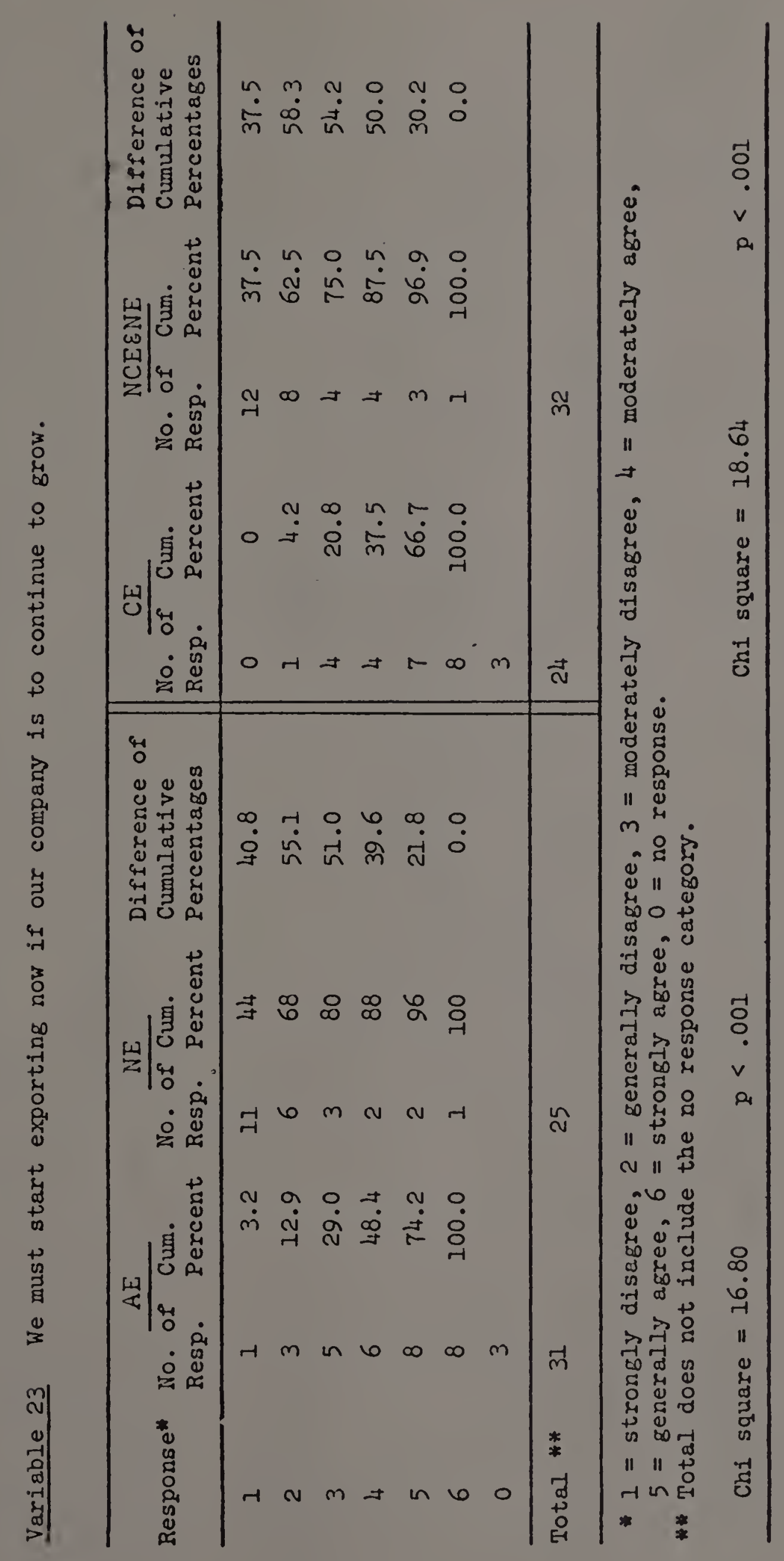




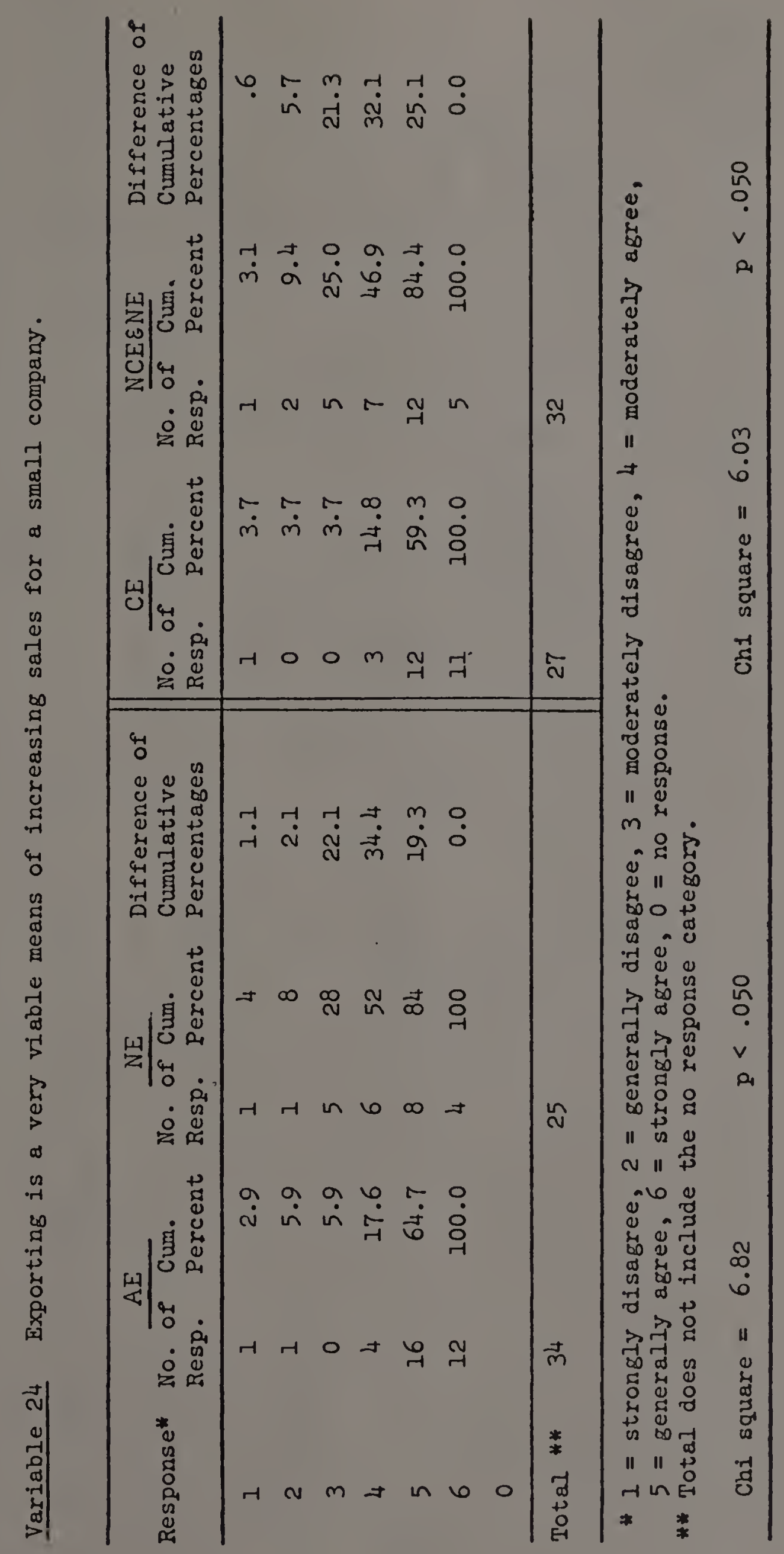




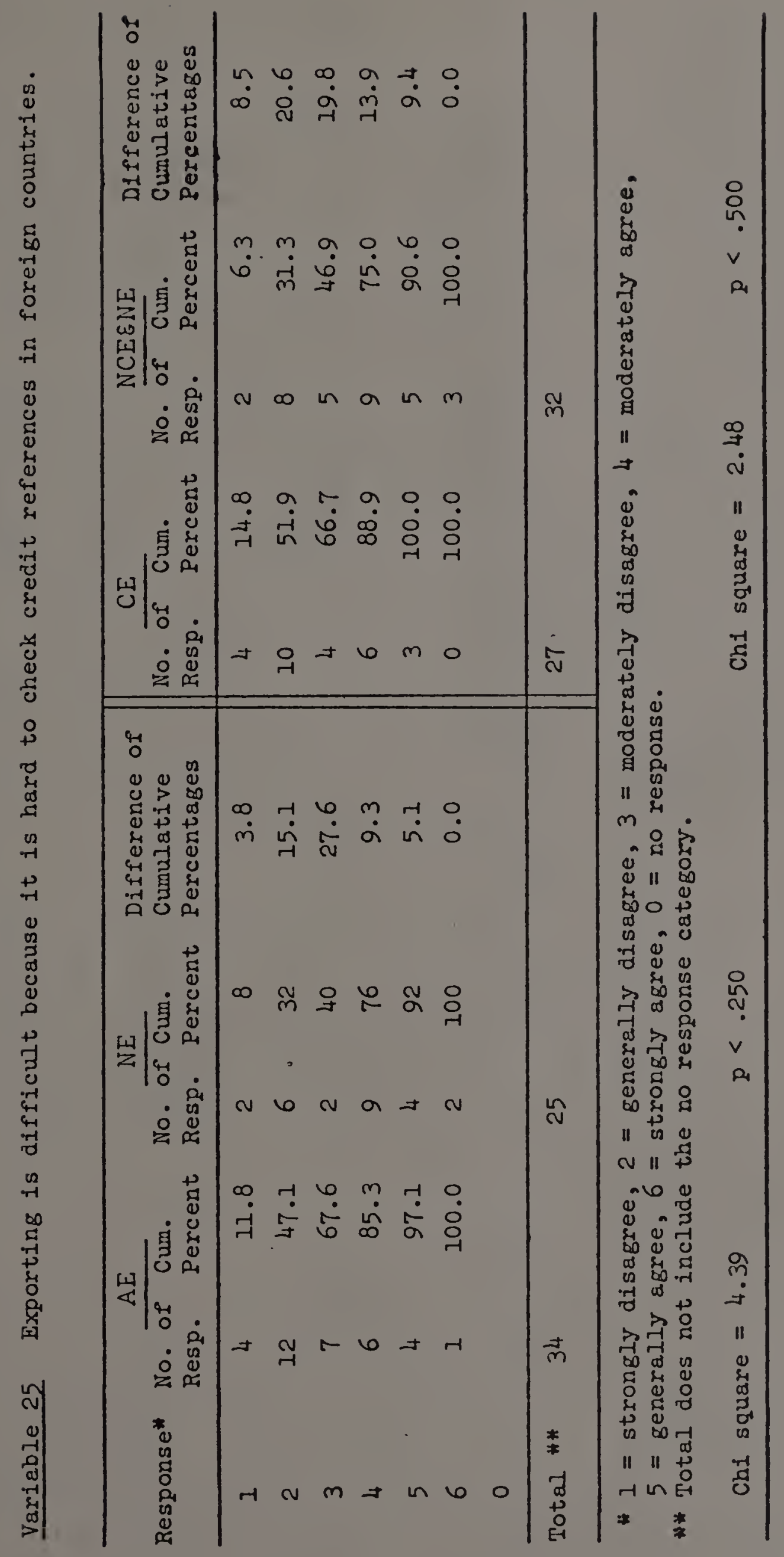




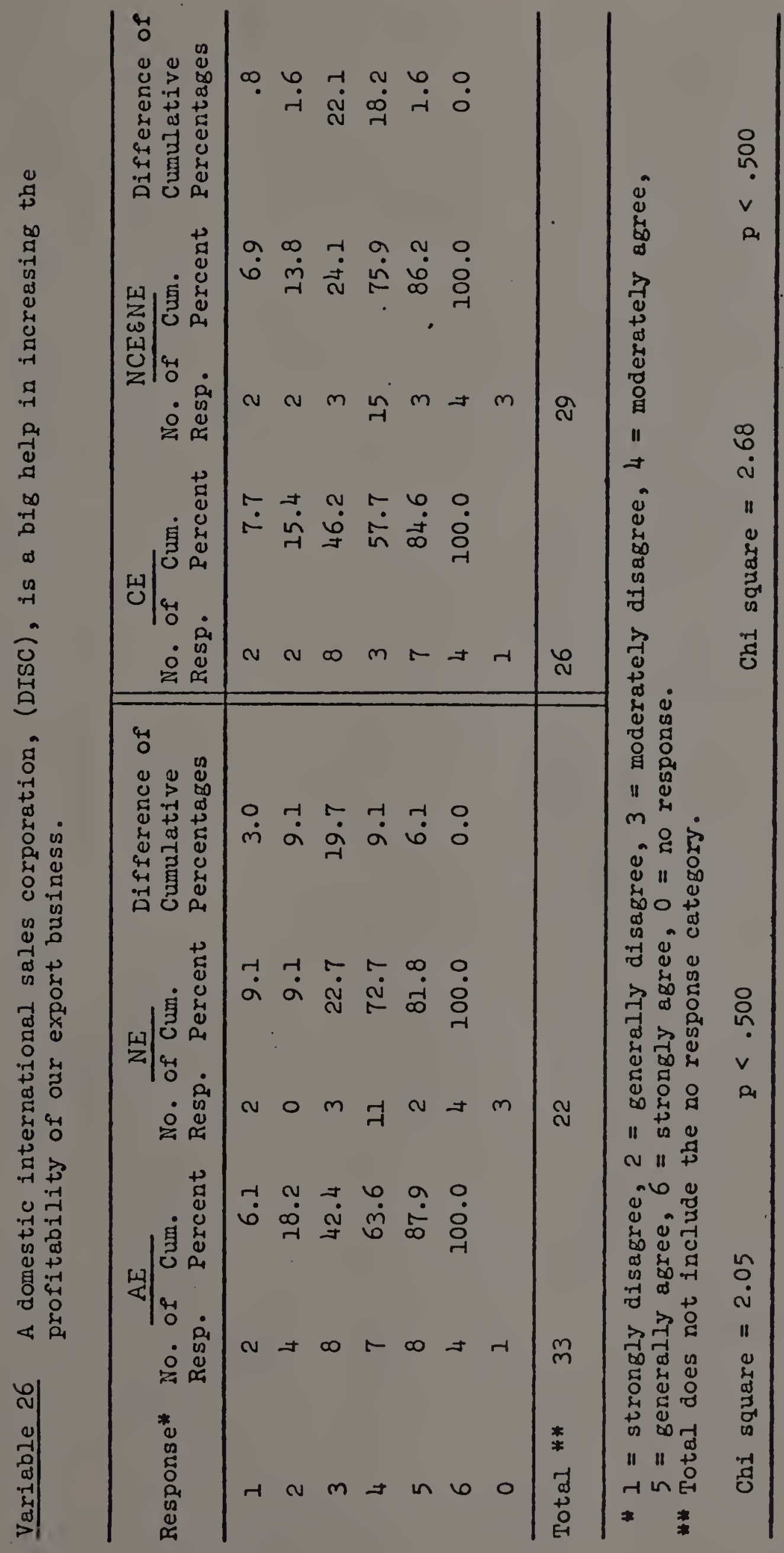




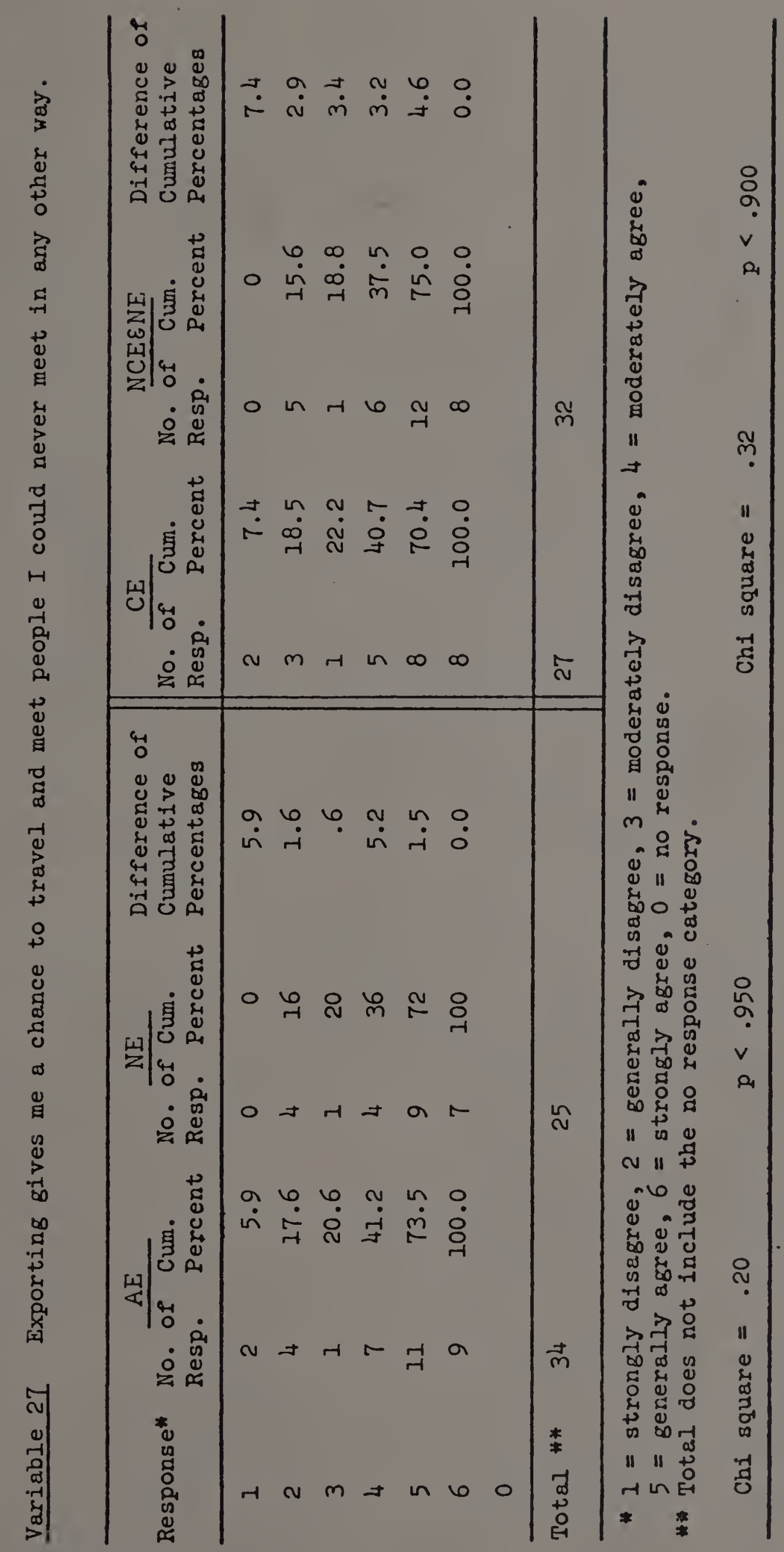




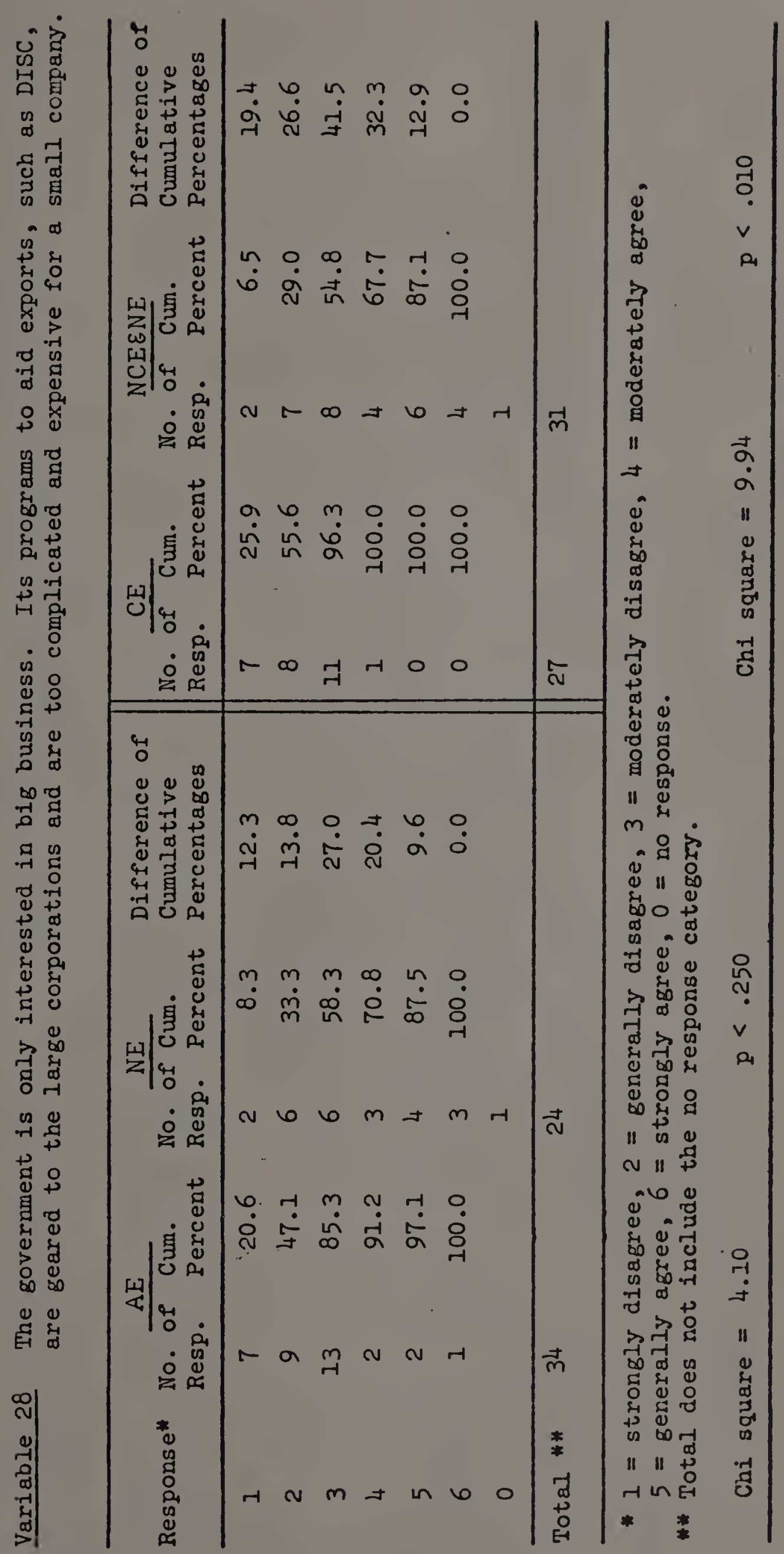




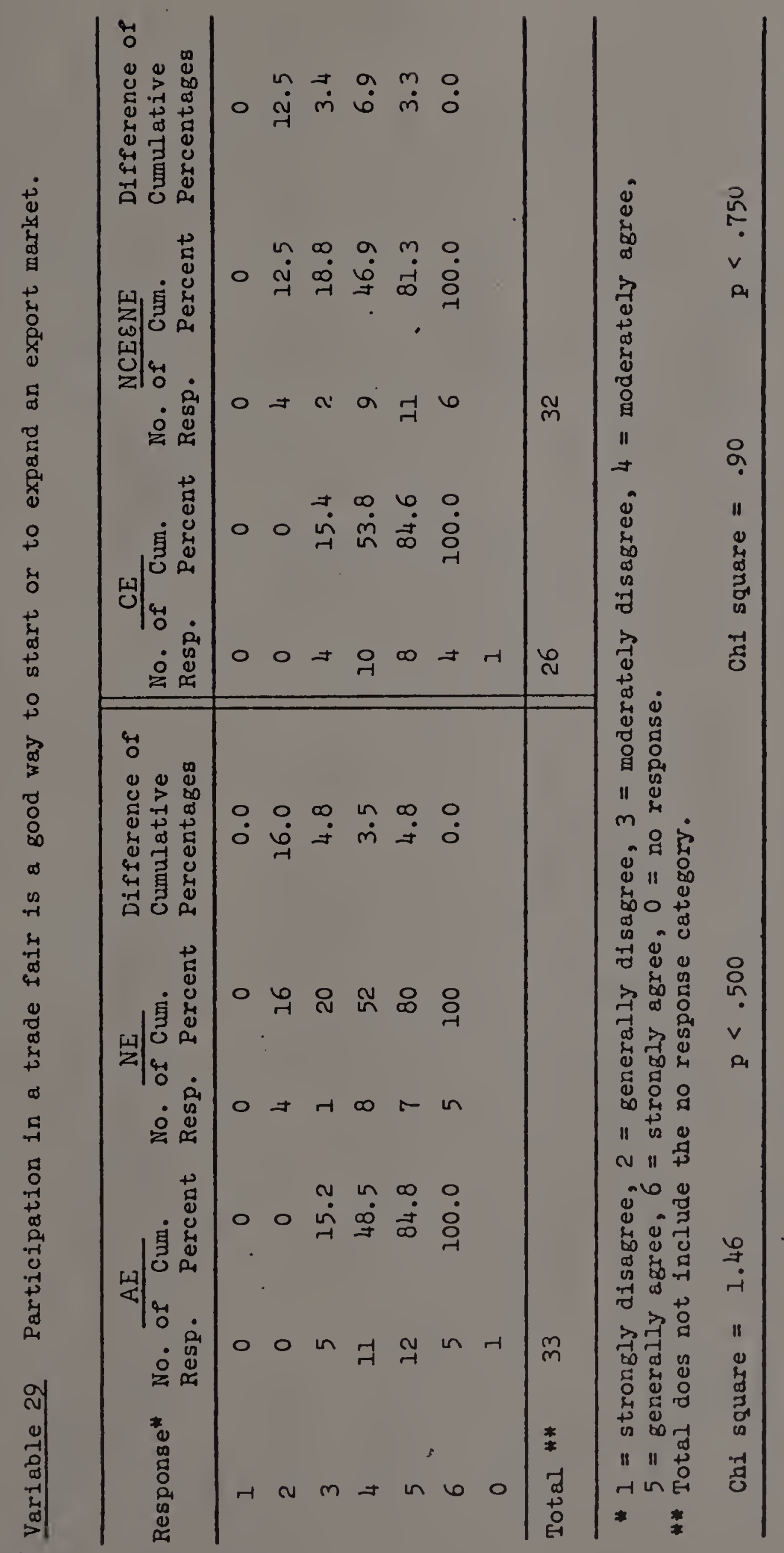




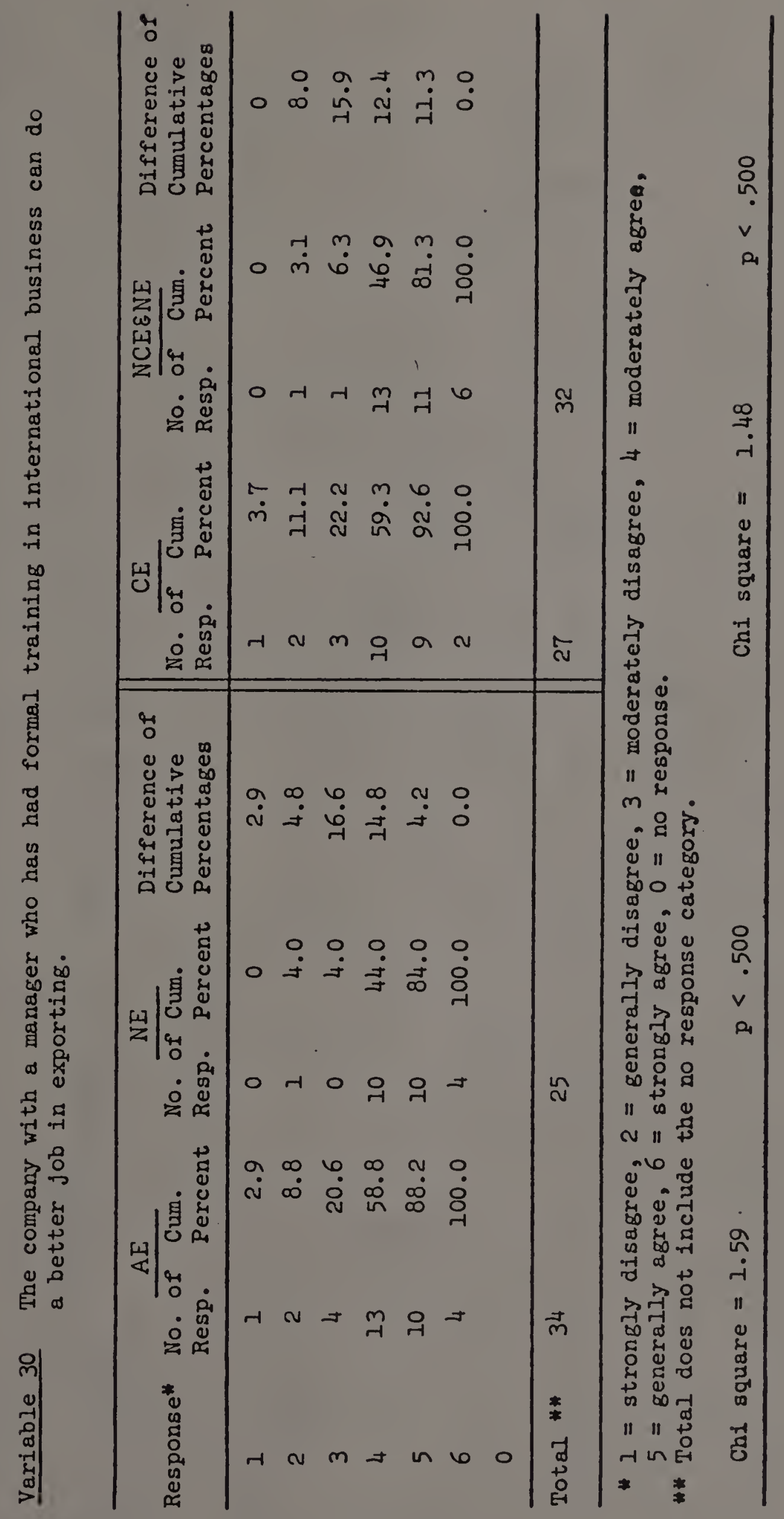




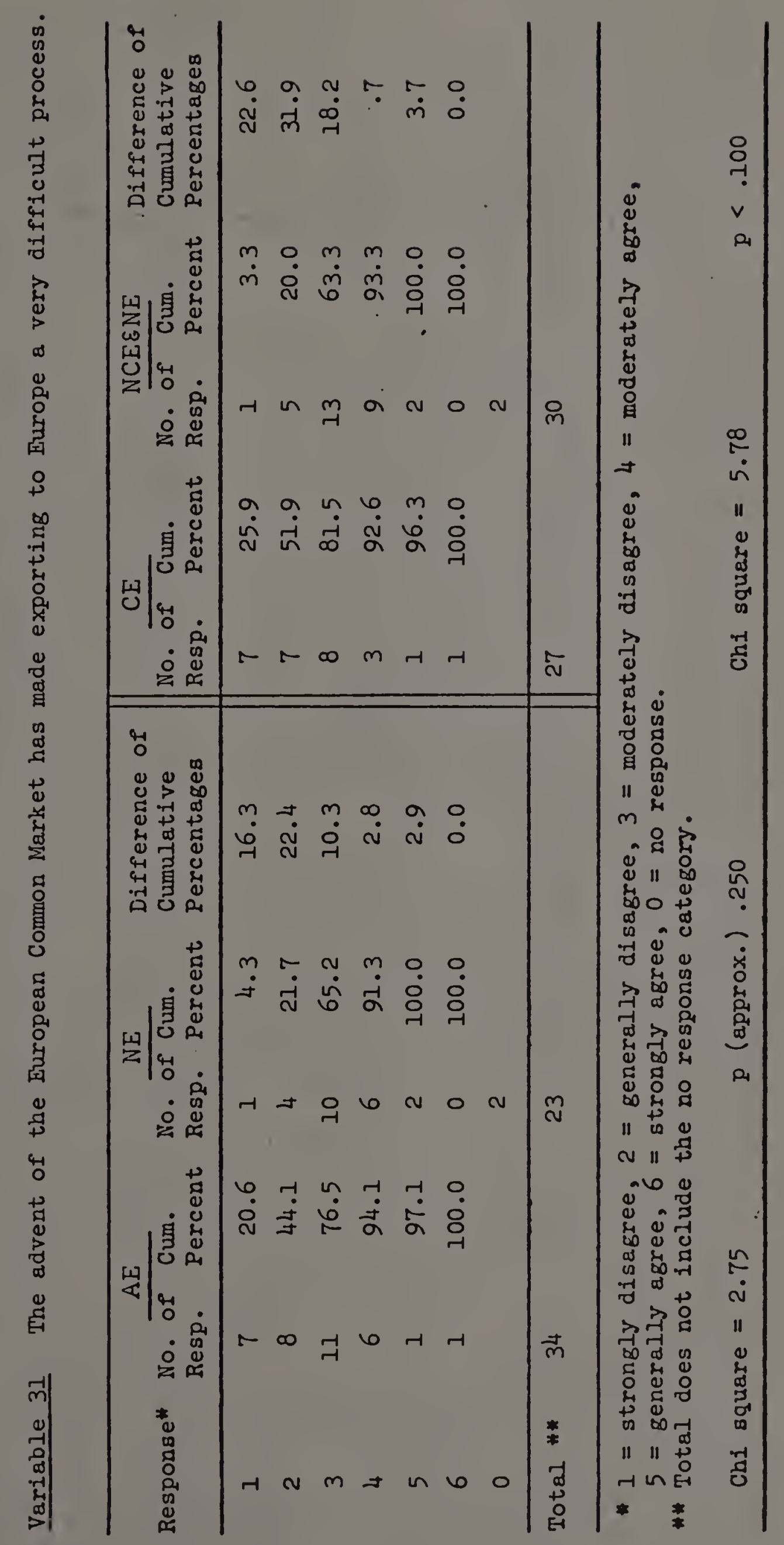




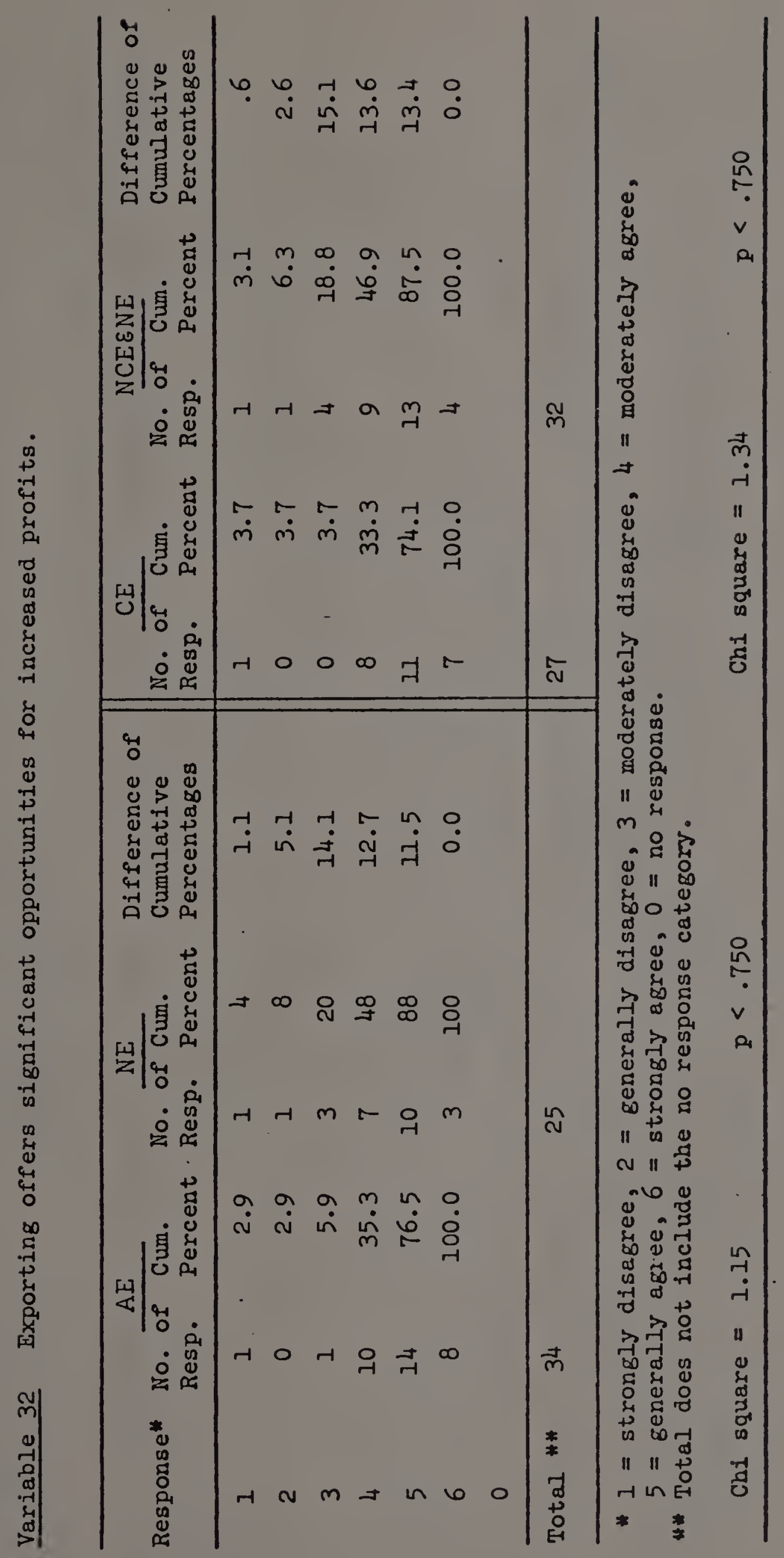




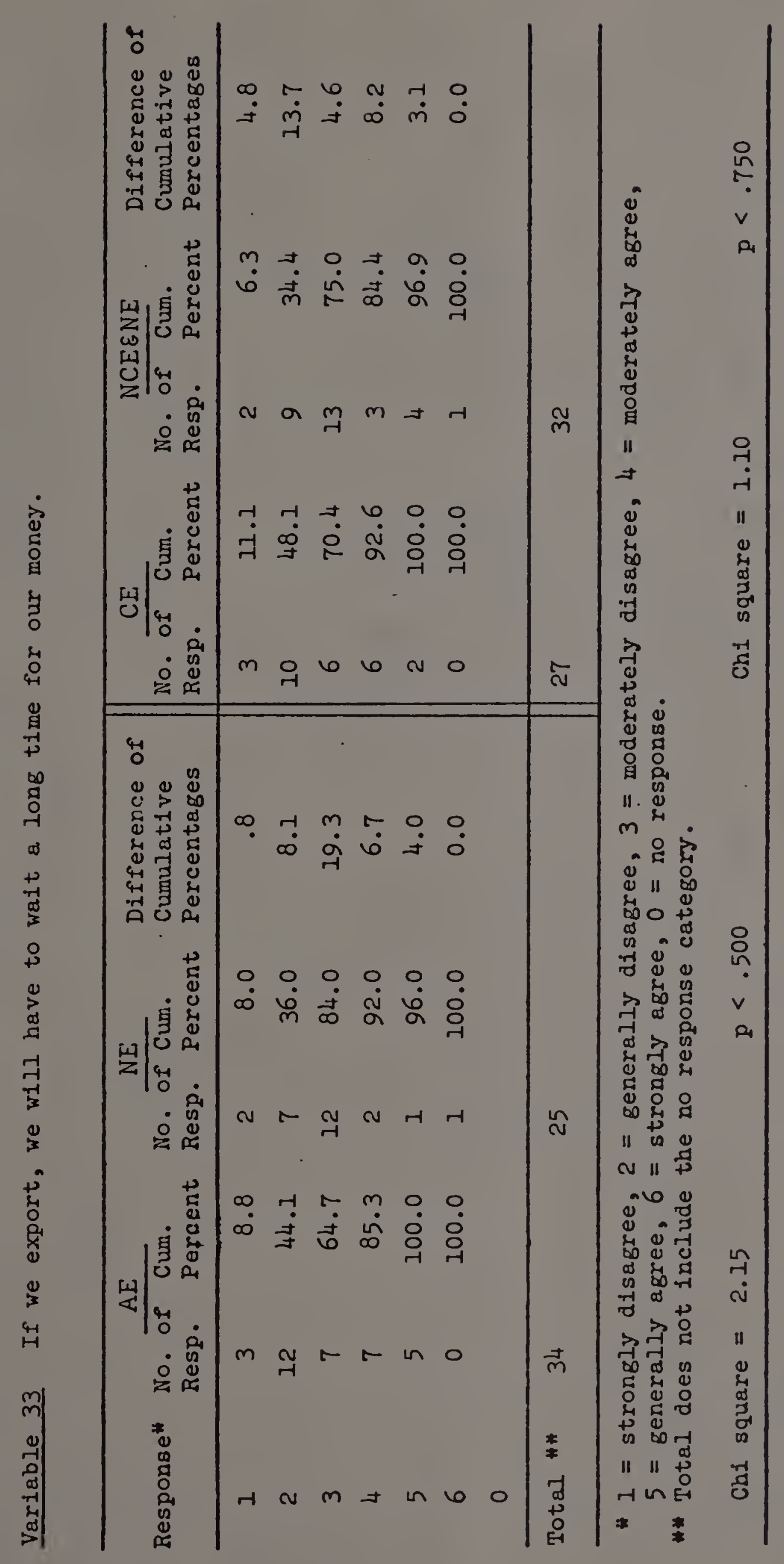




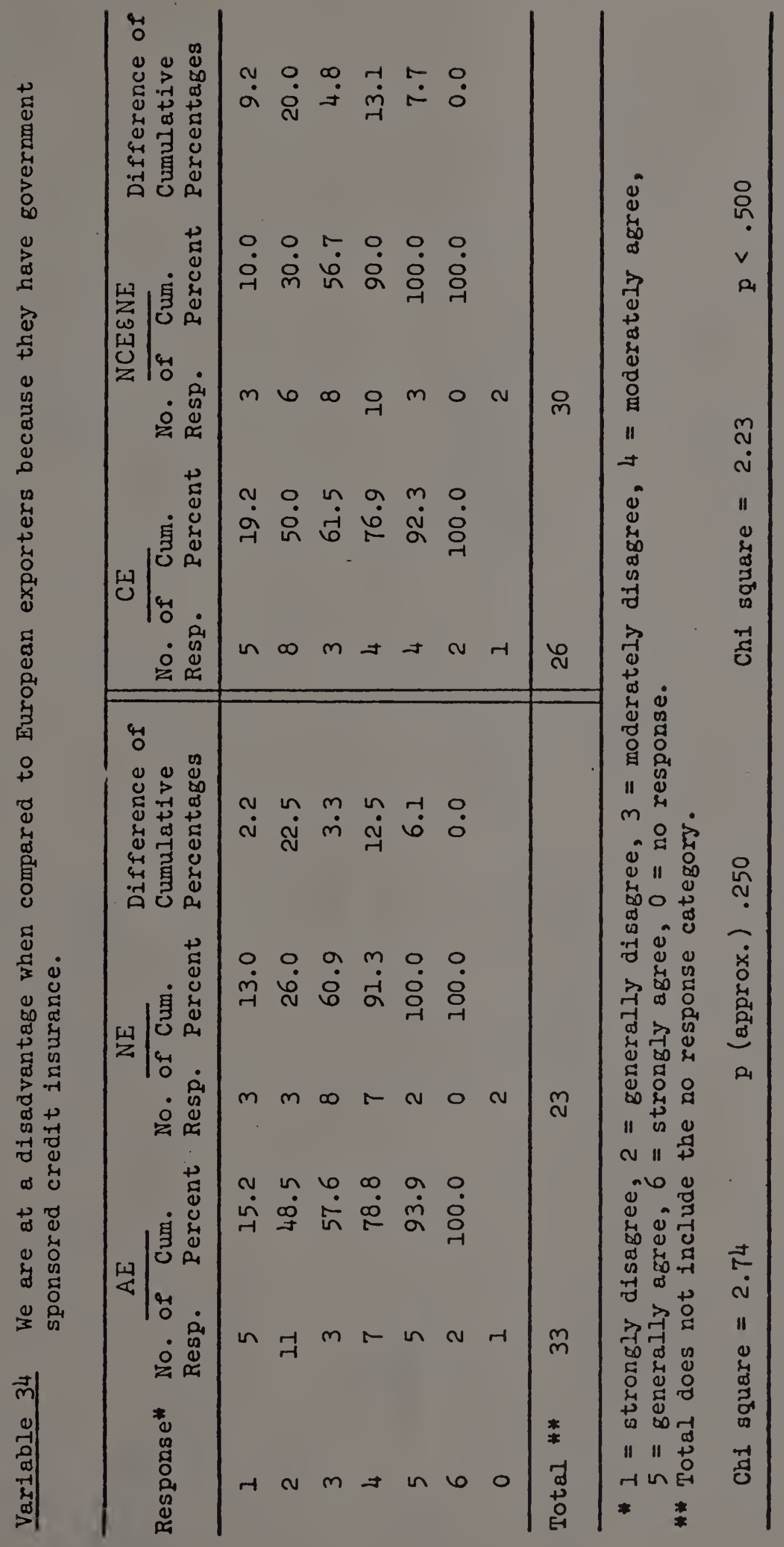




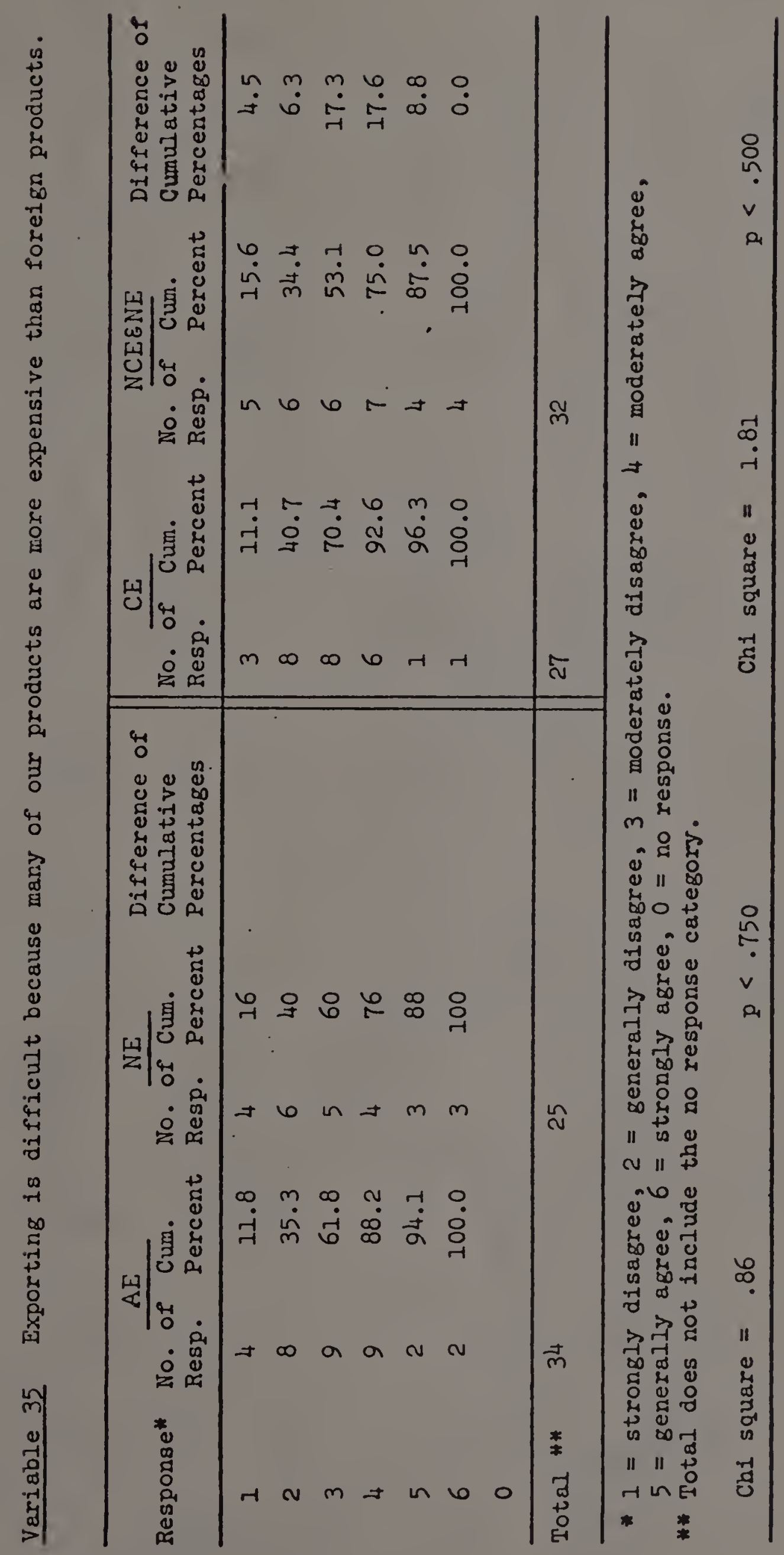




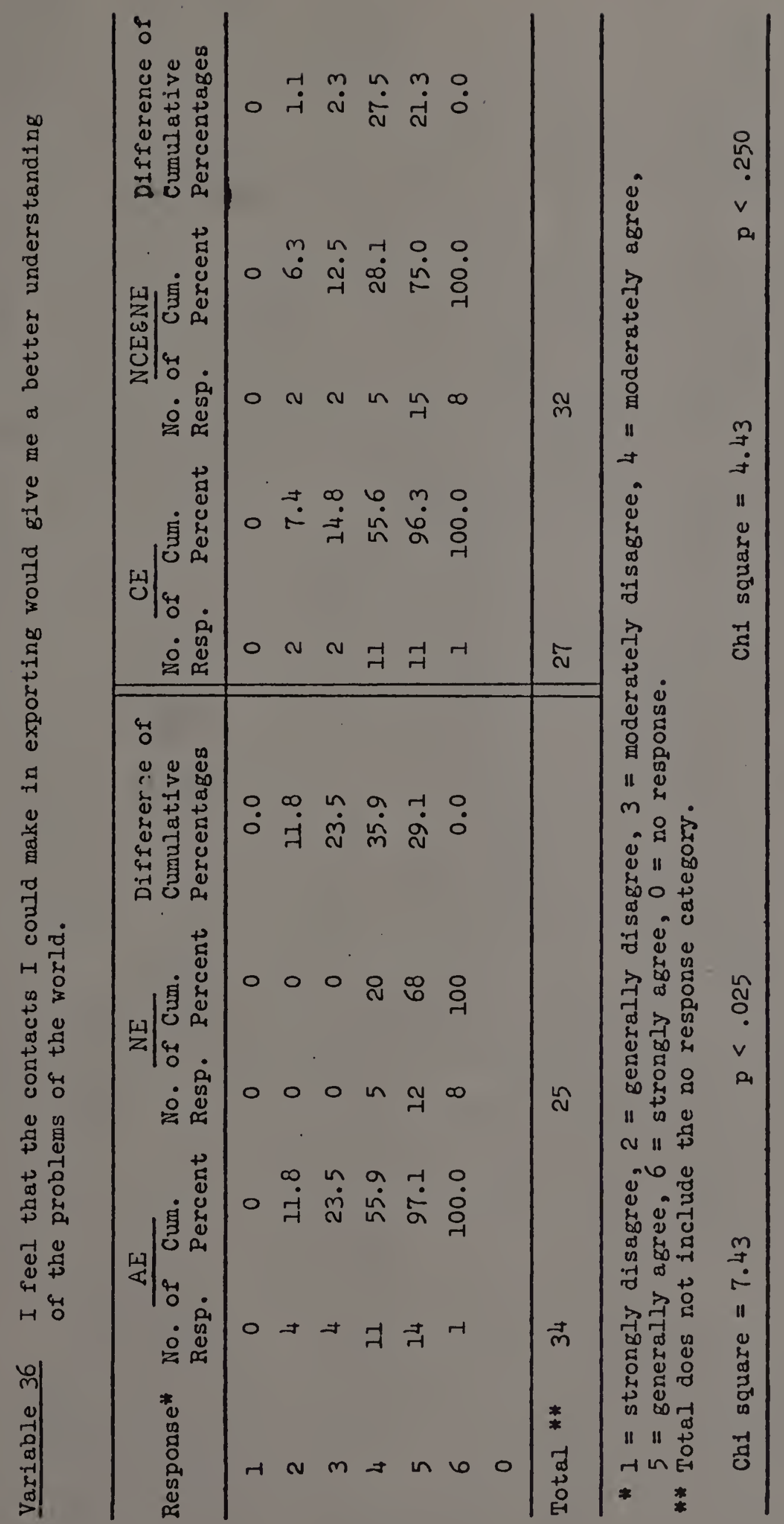




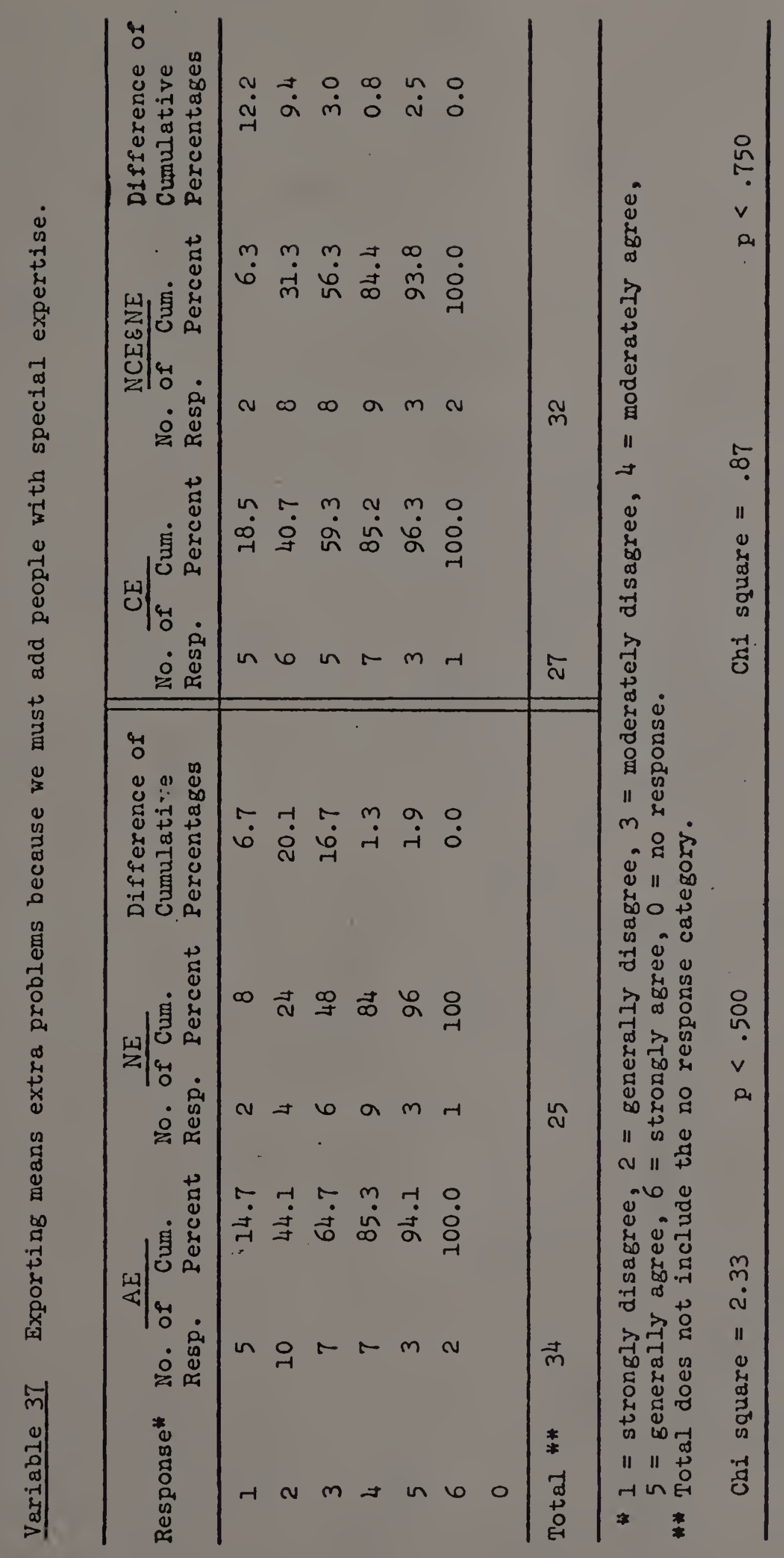




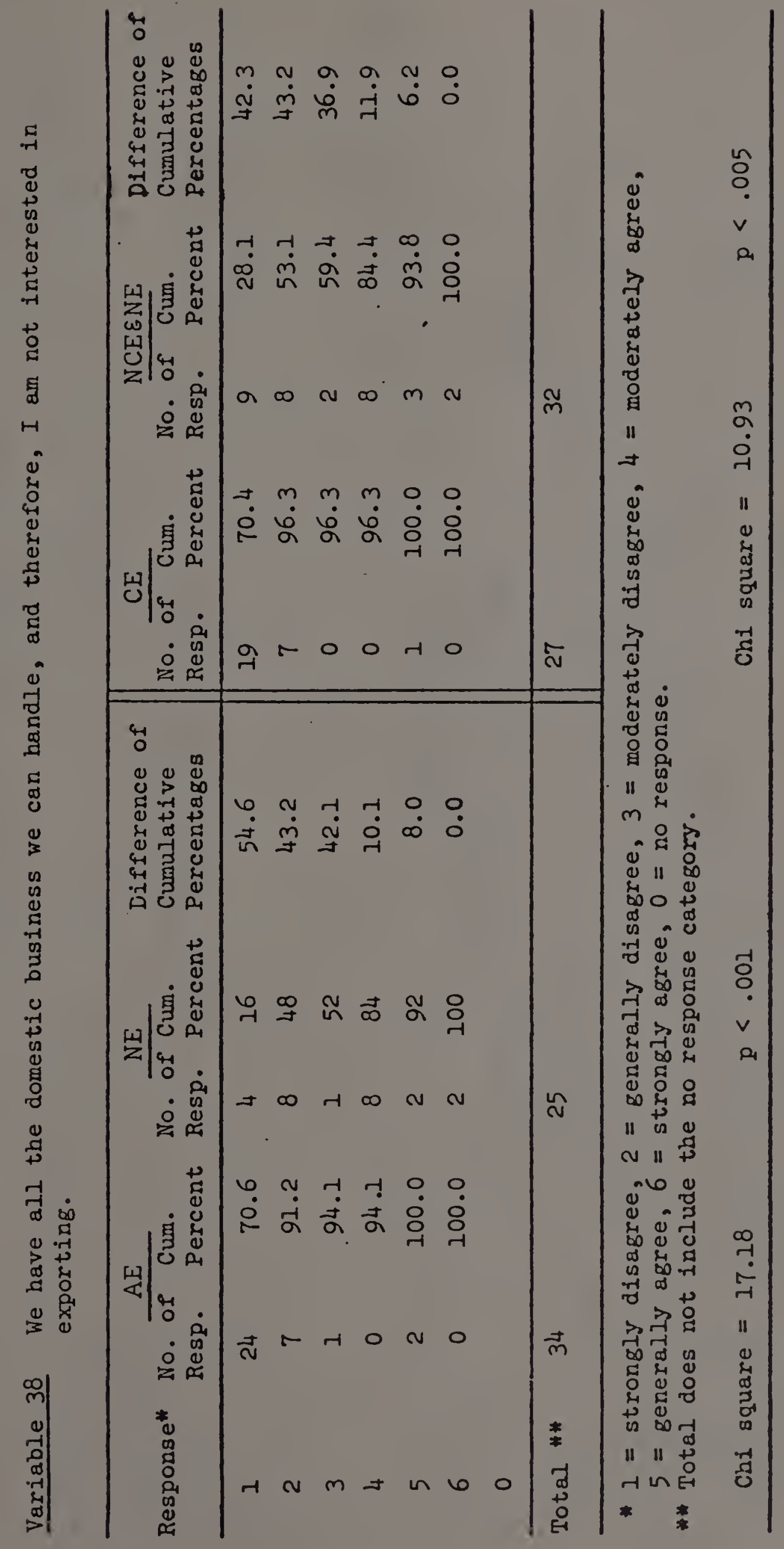




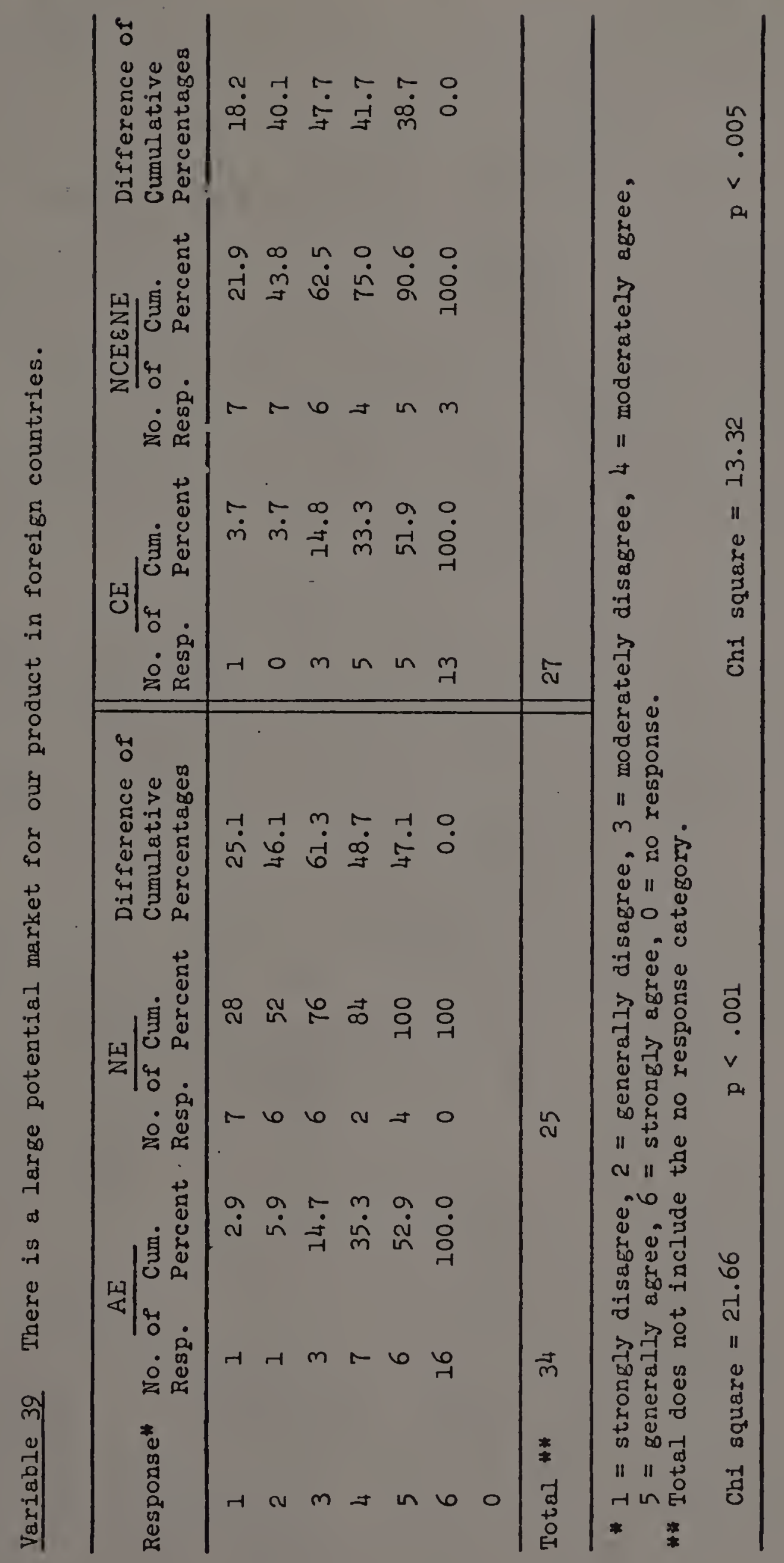




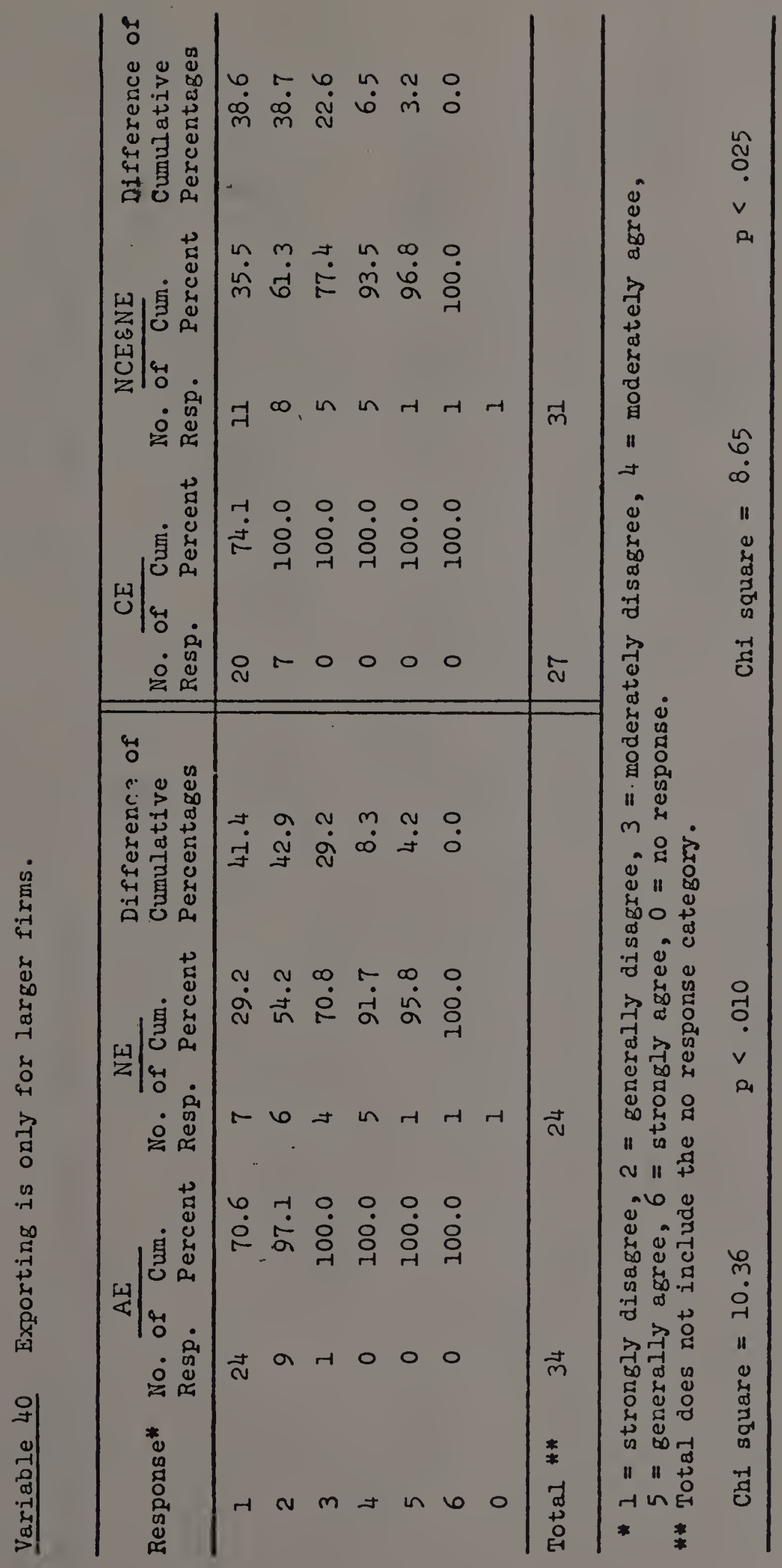




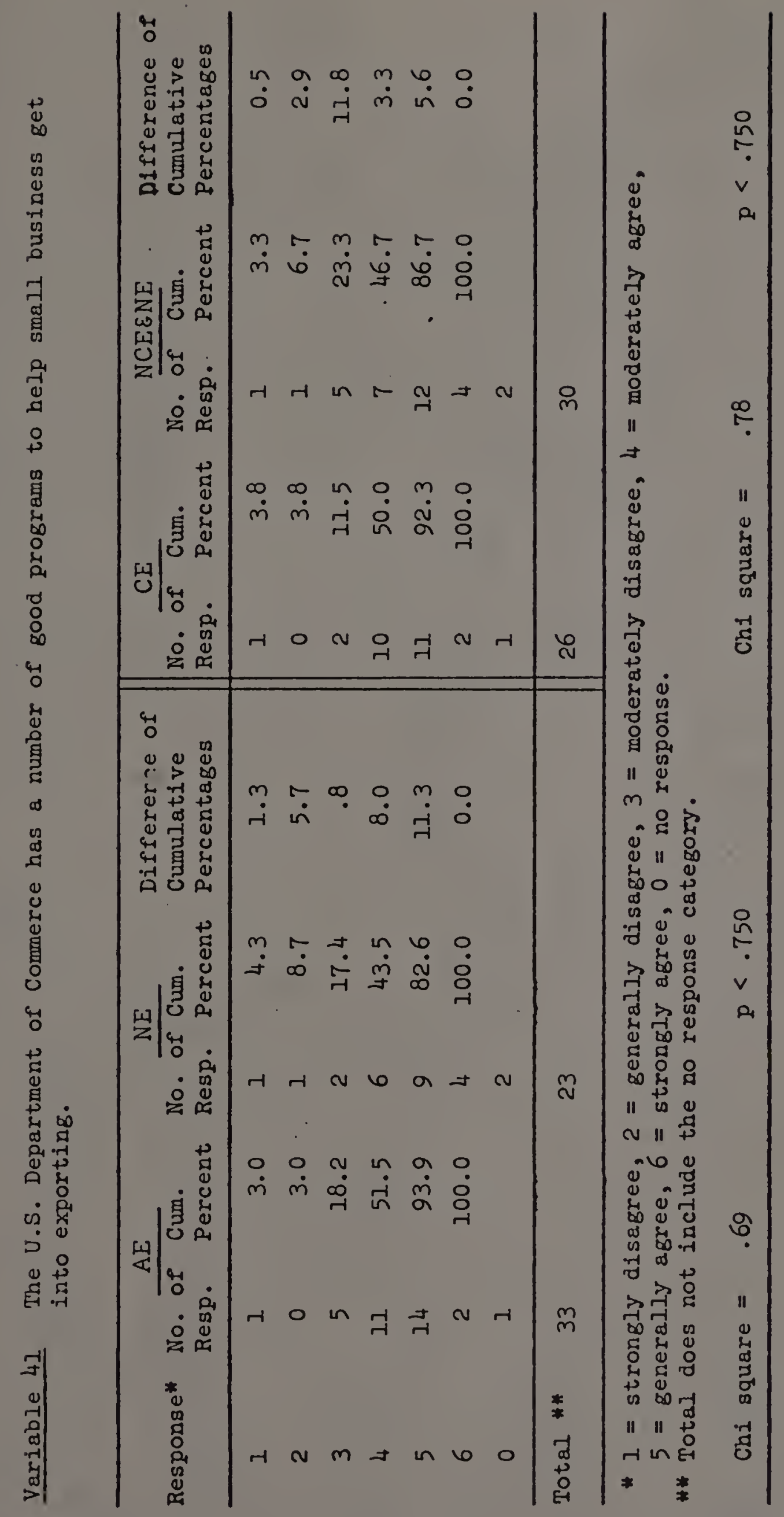




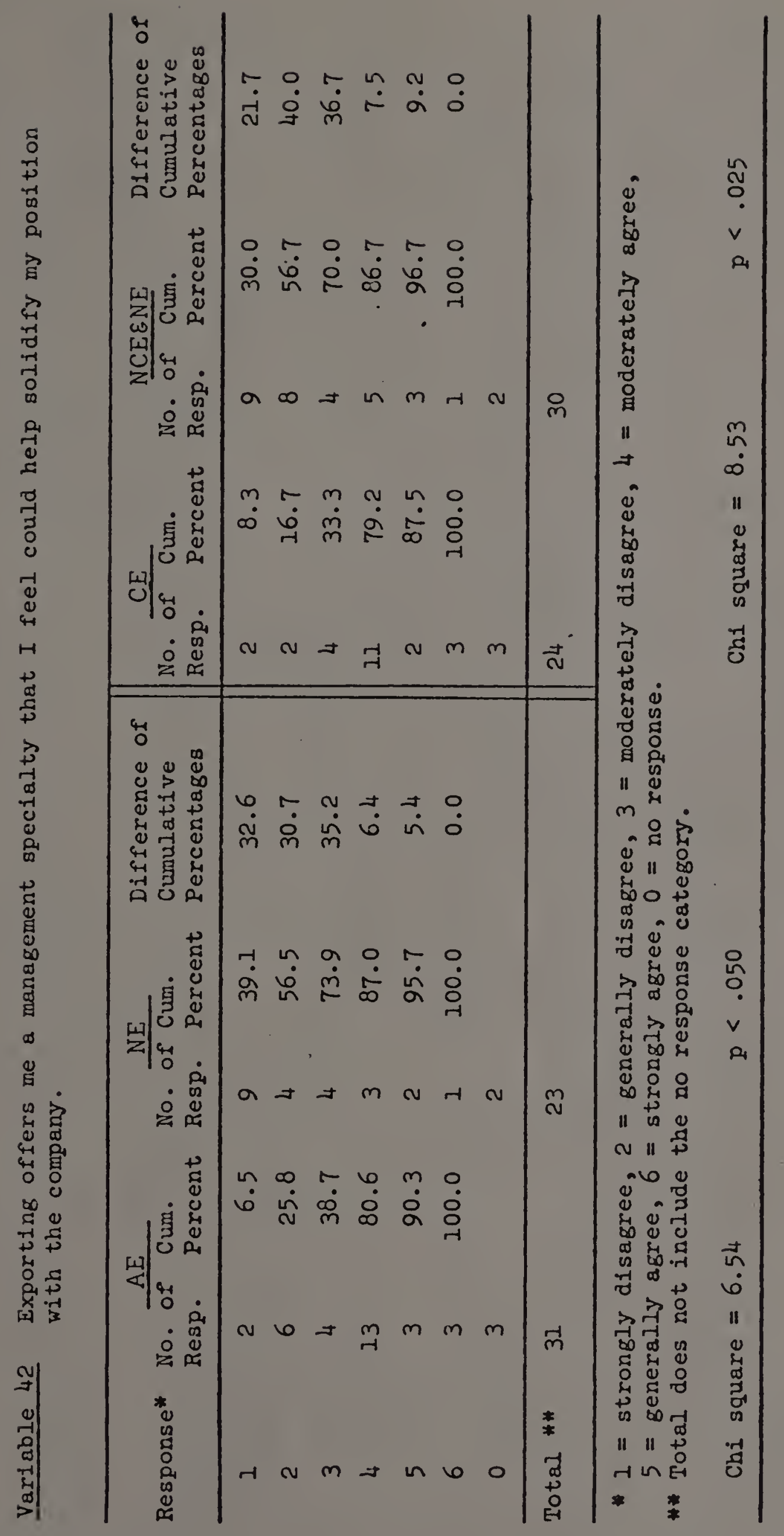




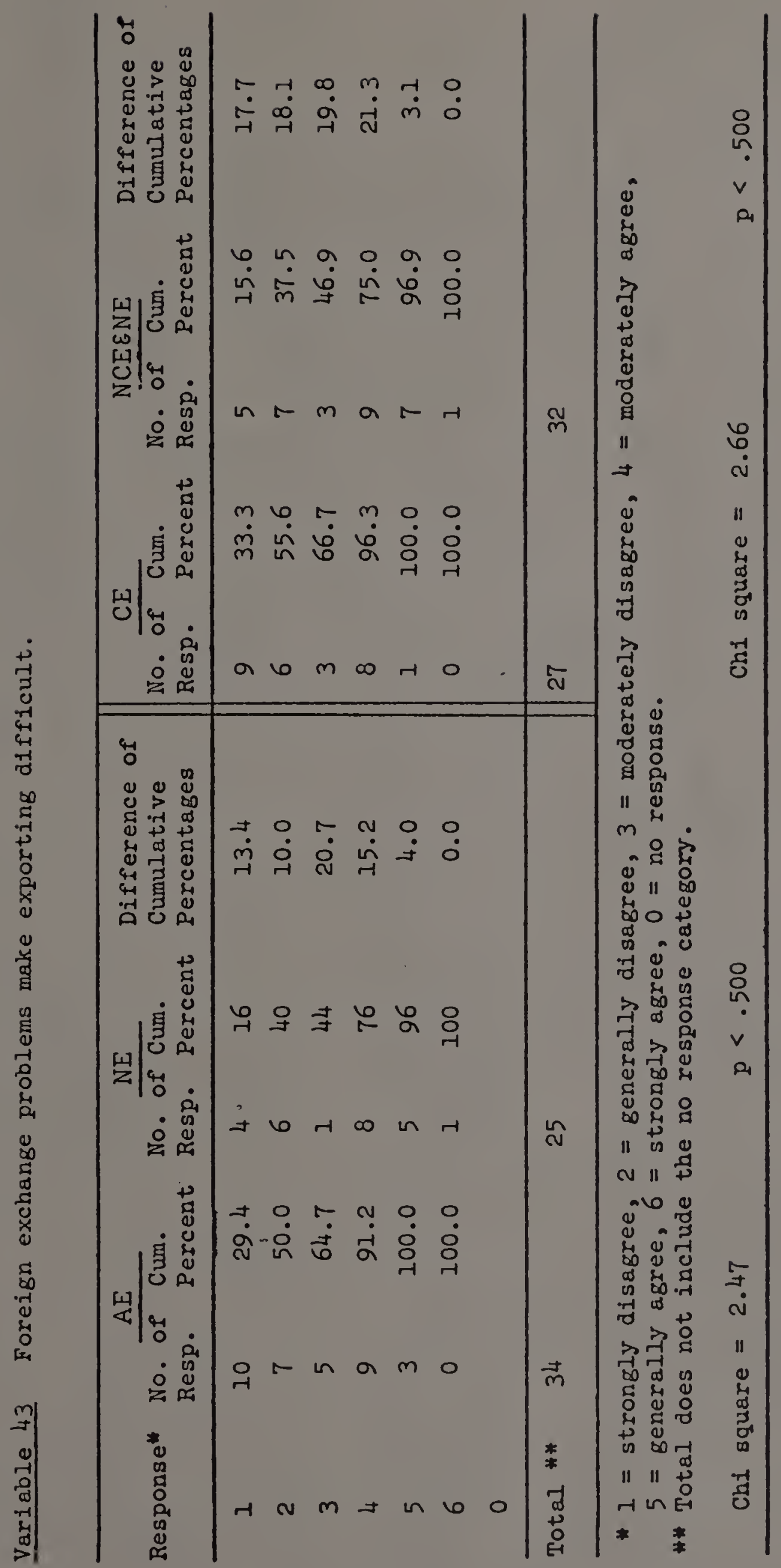




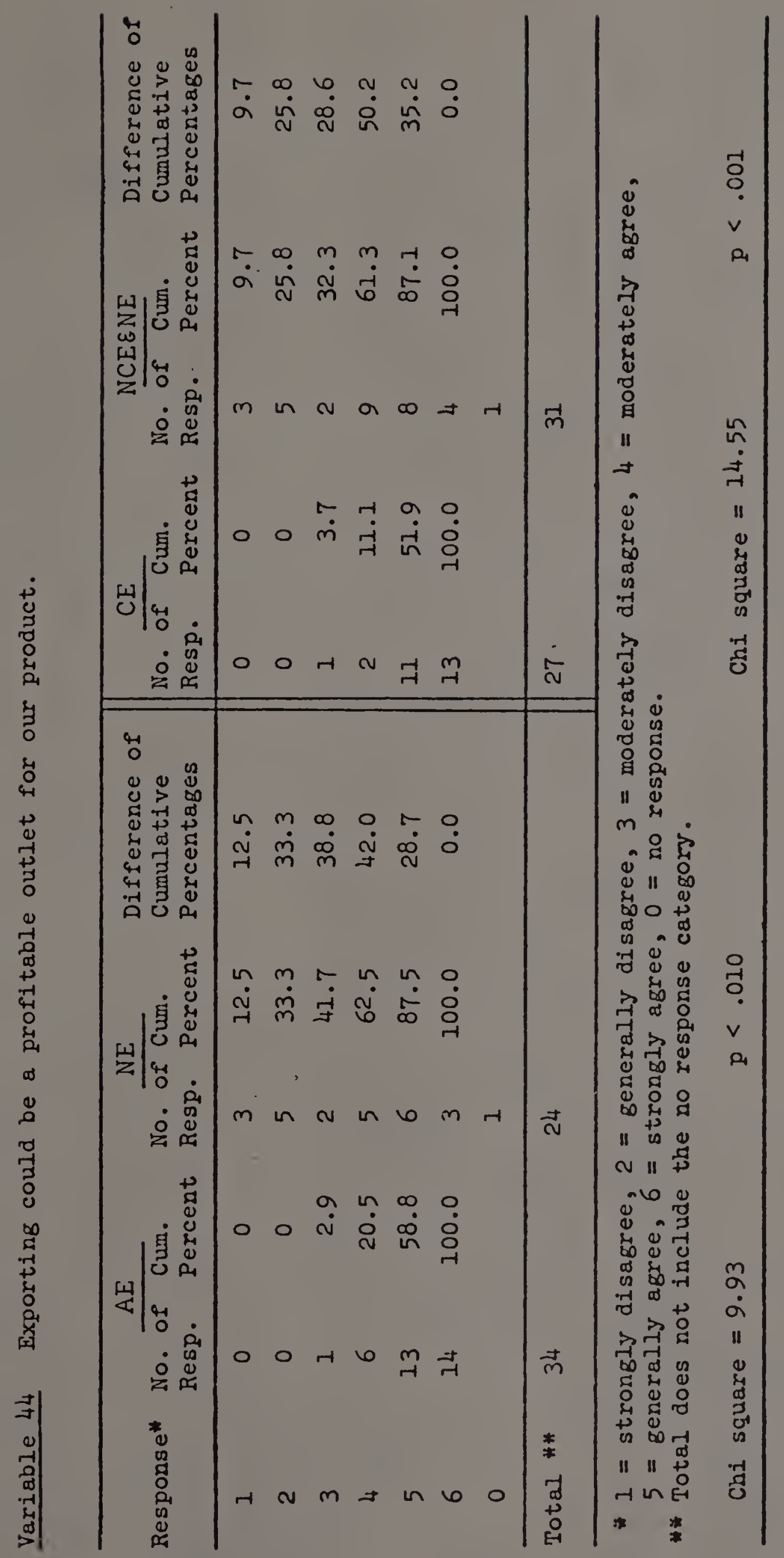




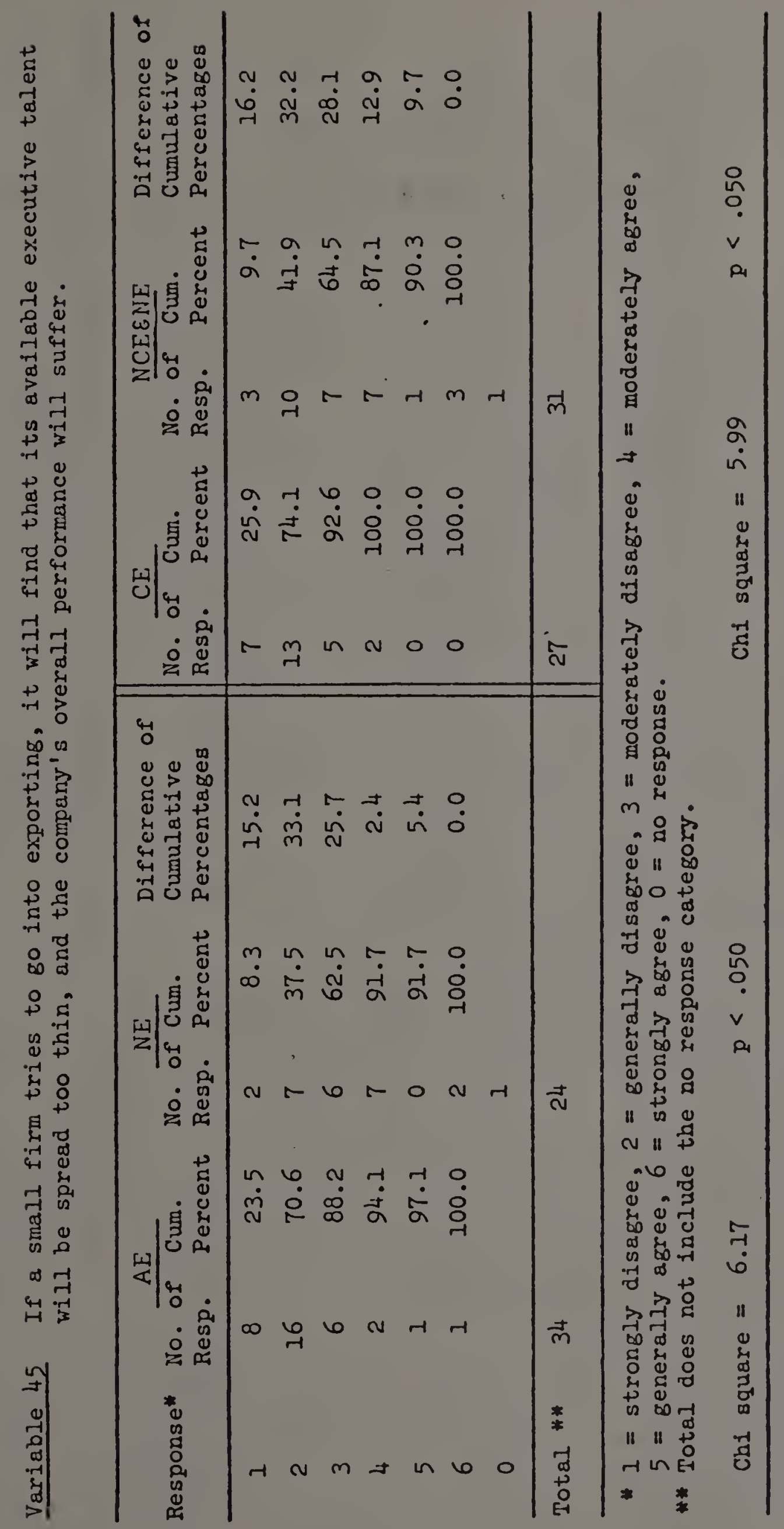




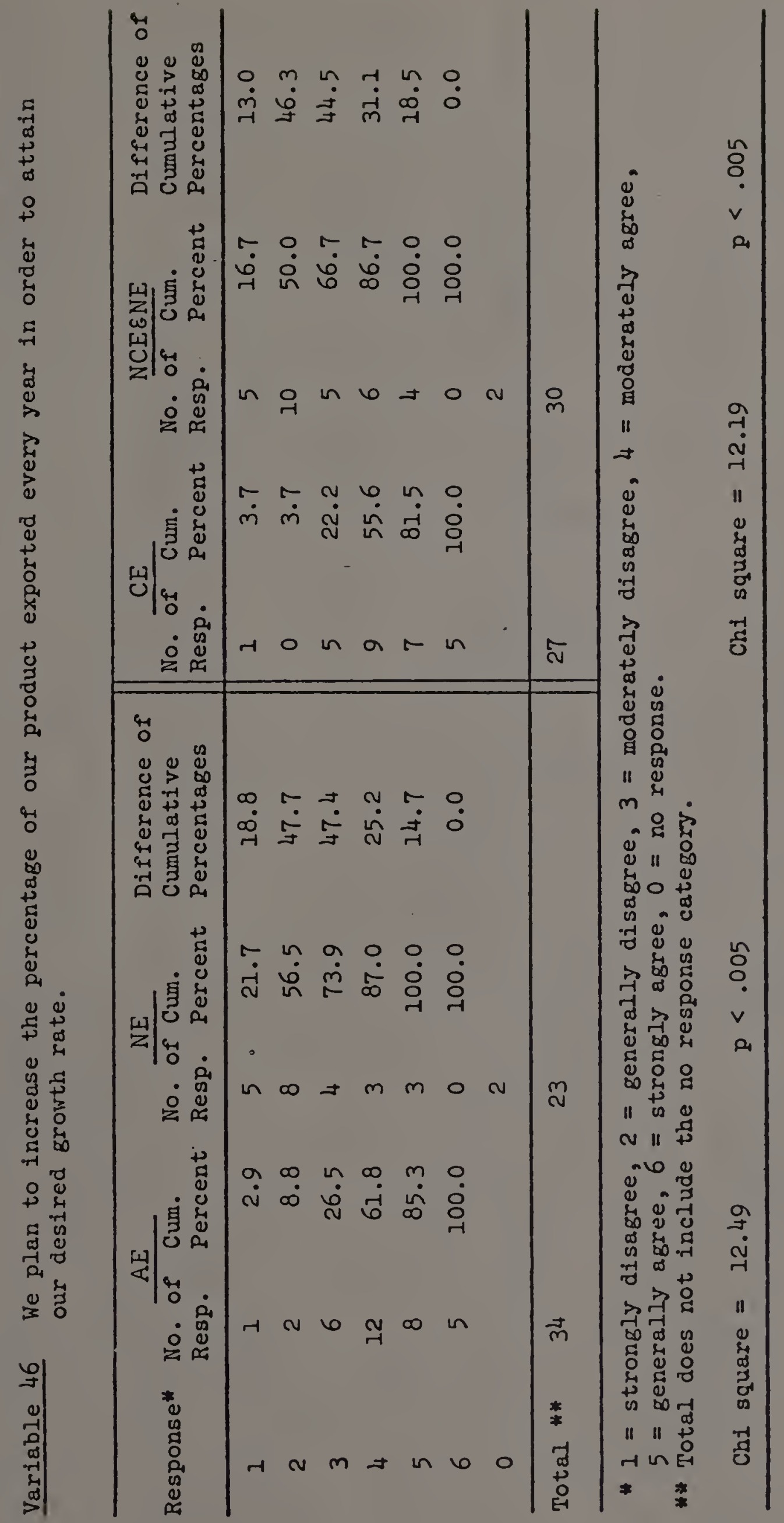




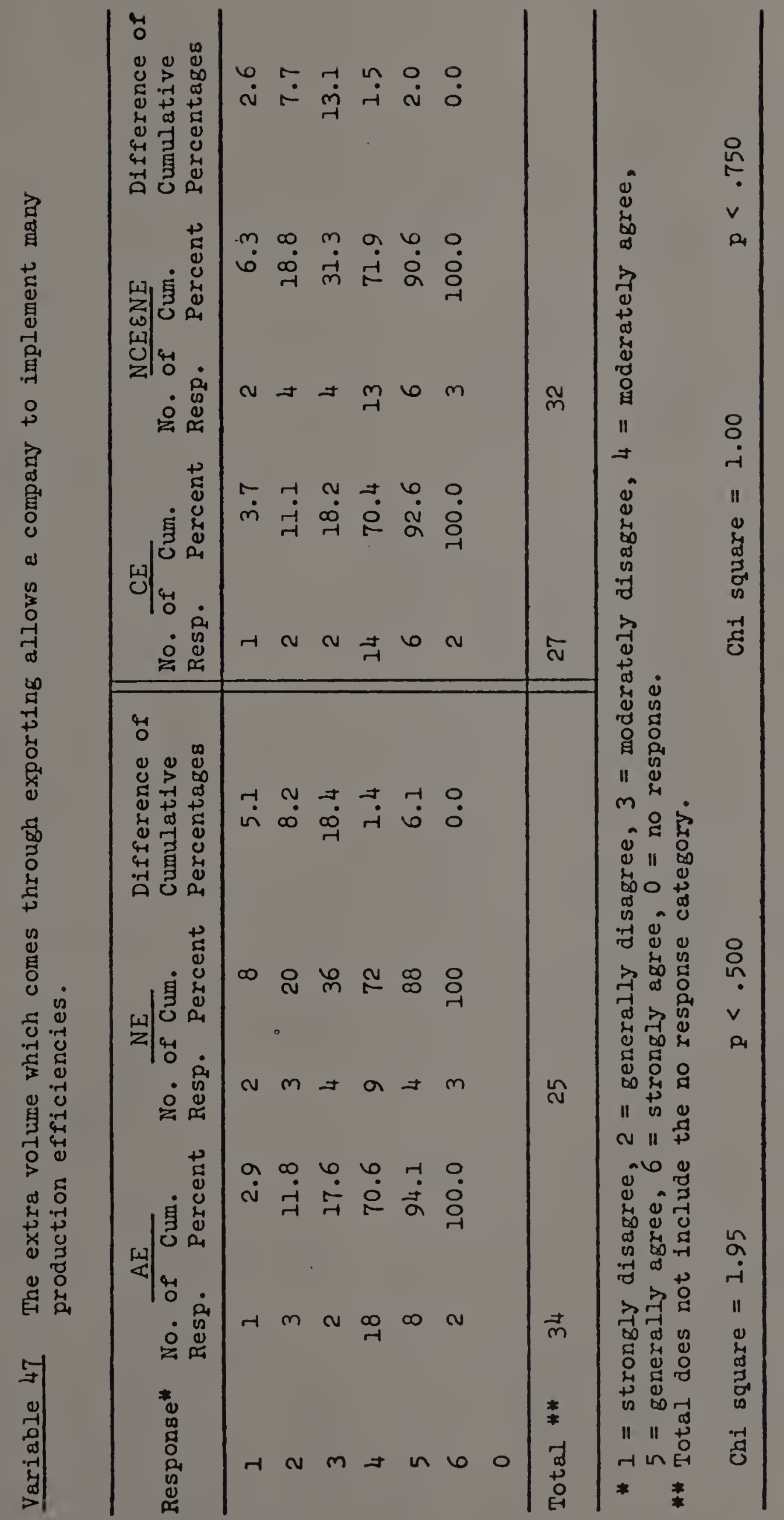




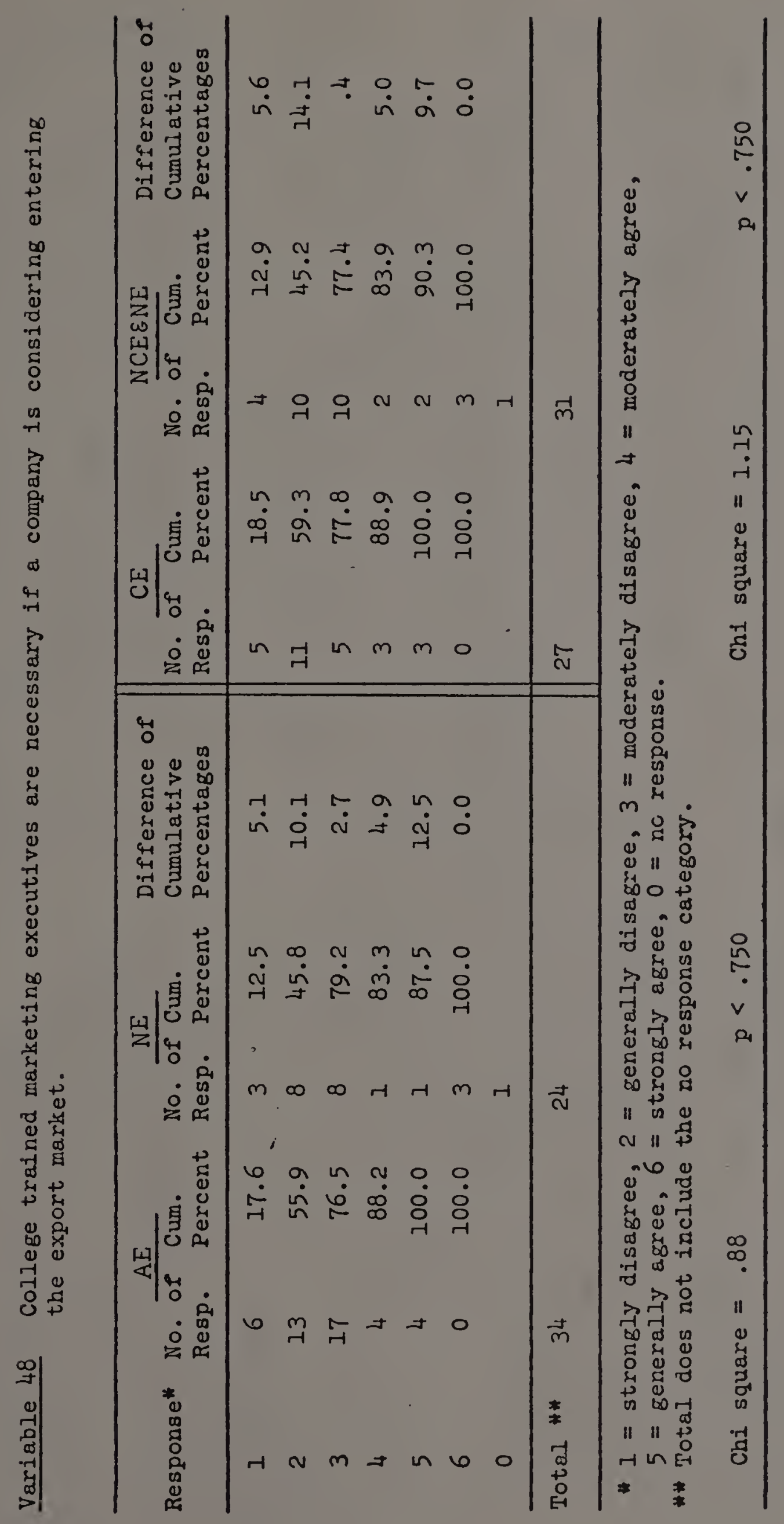




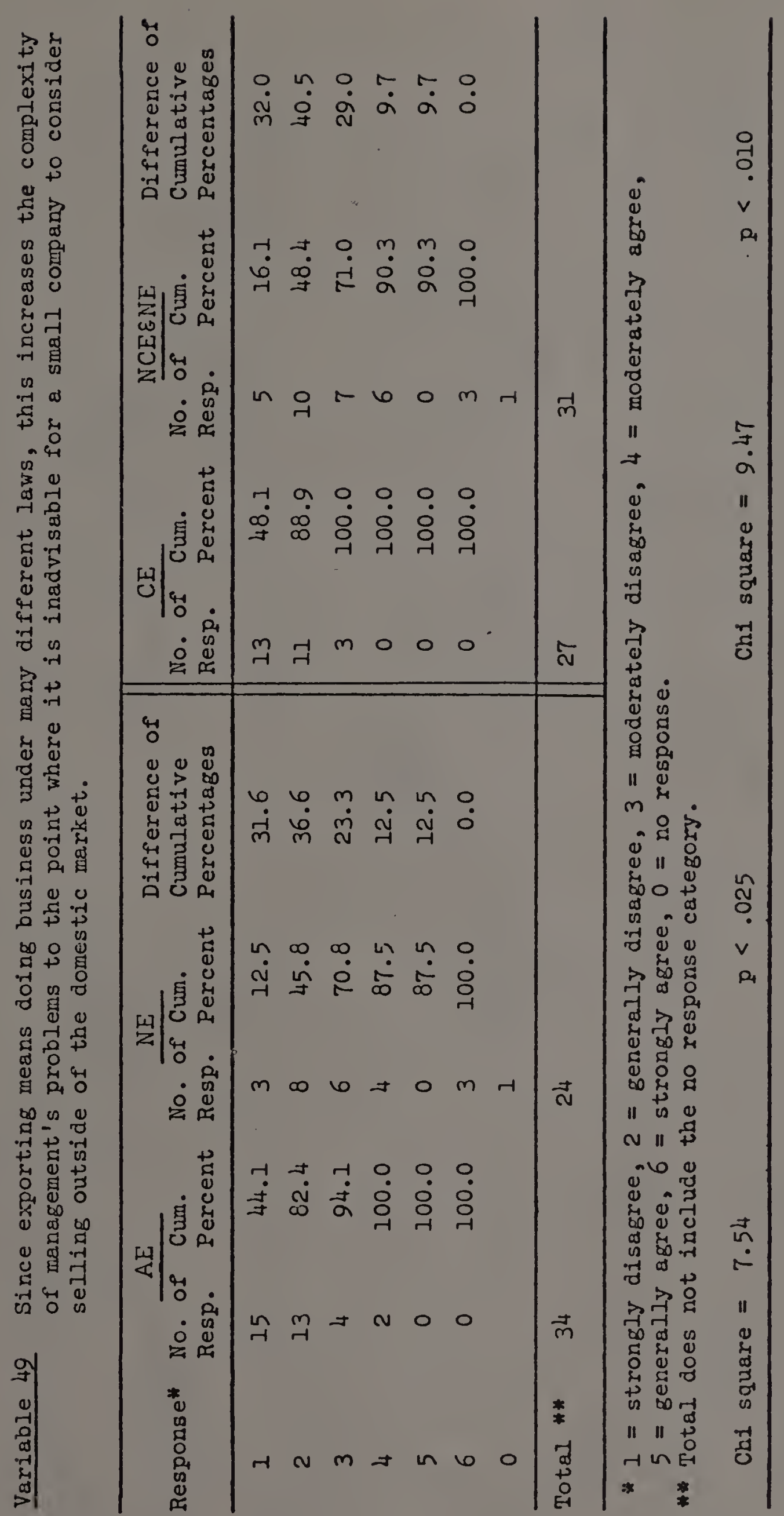


"yมvi 